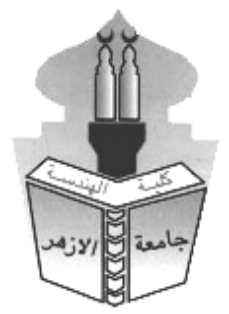

\title{
ARCHITECTURE MOVEMENT BETWEEN STATIC, KINETIC AND DYNAMIC THE IMPACT OF THE APPLICATION OF MOBILE ARCHITECTURE ON MASS FORMATION AND VISUAL IMAGE
}

\author{
Ismail Ahmed Amer \\ Architecture Department, faculty of Fine Art , El Minia University, El Minia, Egypt \\ E-mail: Ismail.Amer@mu.edu.eg
}

\begin{abstract}
The movement of the building is one of the methods of formation and is the method of expressing architectural ideas, and the movement includes both the actual movement and the static movement, a movement that is produced by arranging the elements of origin, its lines, basic forms and levels to give a sense of movement. The dynamic movement was until recently a difficult dream to achieve, but it started to achieve, but it is with a small building, and before that it started in Kintika in large buildings and blocks in several countries, including Egypt and Brazil, and others. And the dynamic dream of the big blocks started to appear on the horizon. For each role to move separately to become one of the points of distinction in the visual image as one of the elements of the quality of urban life, as the research deals in the first part with the research introduction and presents the research problem and the importance and objectives and hypotheses and questions and methodology of the research, then in the second part deals with definitions related to the topic of research to be transferred In the third part to the historical background, it deals with the movement in contemporary architecture, to move to the fourth and fifth parts and review deconstructive architecture and dynamic architecture as major design trends in contemporary architecture, and in the sixth part deals with the study of the design process to demonstrate how the direction of movement in architecture as a design trend can contribute to creativity In architectural design, and in the seventh part it deals with explaining how design trends affect the visual image of cities and consequently on the quality of urban life, so that the research in the eighth part reaches practical study - relying on it on the curriculum Leila - including concludes Checklist Check List to end your search results and recommendations. The research concluded that the movement in architecture as a design trend has a major role in shaping the visual image besides it is one of the factors for improving the quality of urban life through the production of contemporary mass formations that are distinctive signs of cities
\end{abstract}

\section{KEYWORDS: Dynamic Architecture,Architecture Of Kinetic, Mass Formation, Quality of Urban Life, Movement, Static Movement, Static Dynamics, Visual Image, Bright Spots}




\author{
حركة العمارة بين الساكنة و الكينتيكاو الايناميكية أثر تطبيق العمارة المتحركة علي البمري \\ تثكيل الكتلة و الصورة البصرية البنية

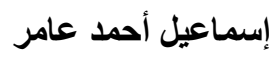

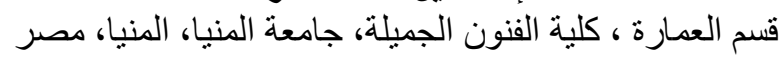 \\ E-mail:Ismail.Amer@mu.edu.eg: البريد الاليكترونية، الفئني
}

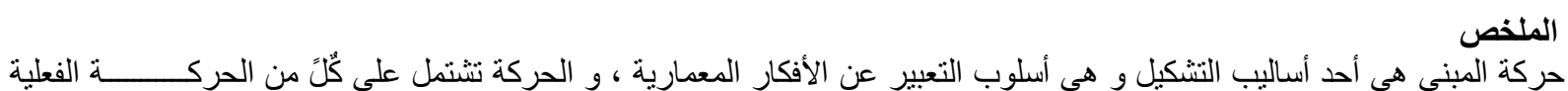

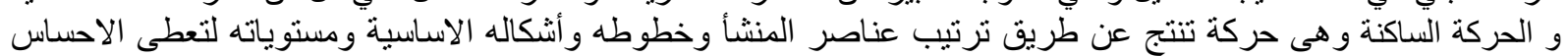

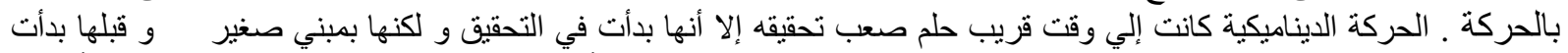

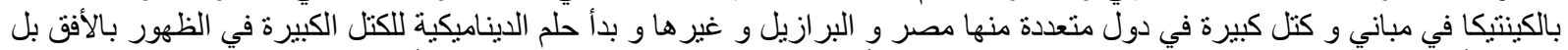

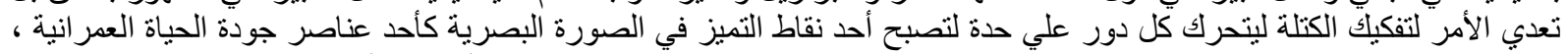

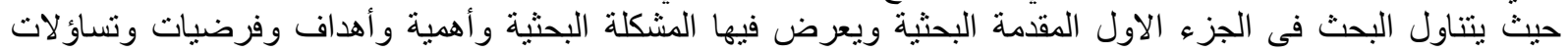

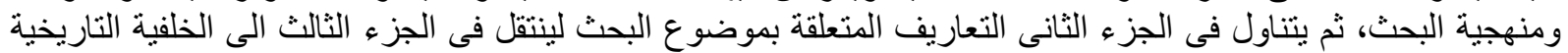

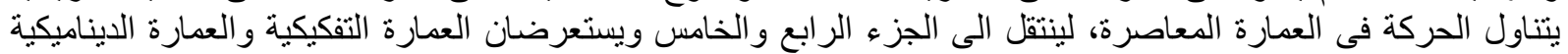

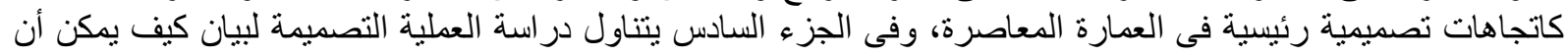

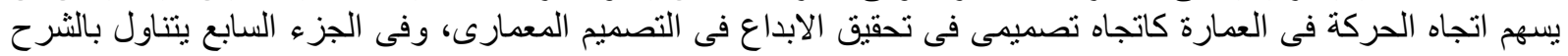

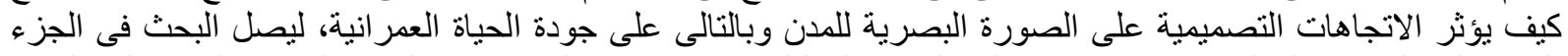

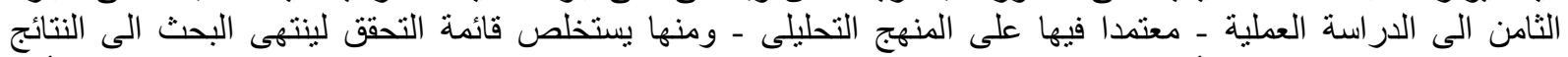

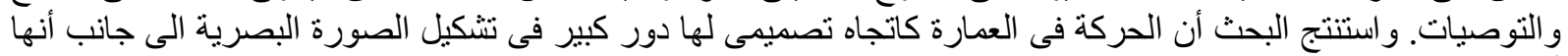

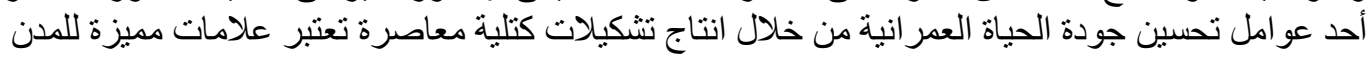

\title{
الكلمات المفتاحية : العمارة الديناميكية ،الكينتيكا ، التثكيل الكتلي، جودة الحياة العمرانية ، الحركة ، الحركة الإستاتيكية ، الصورة البصرية ، التقاط المضيئة الكينة
}

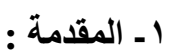

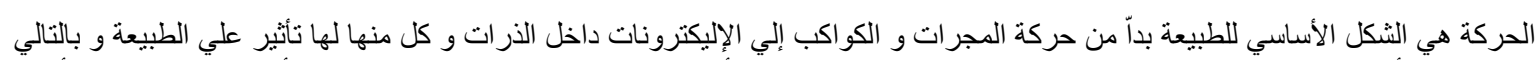

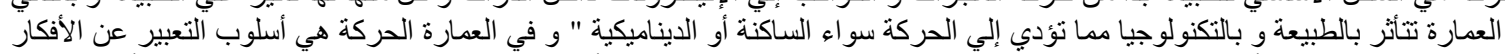

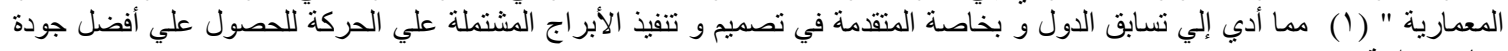
حياة عمر انية

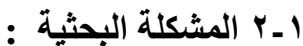

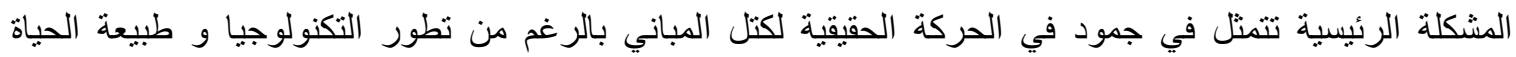

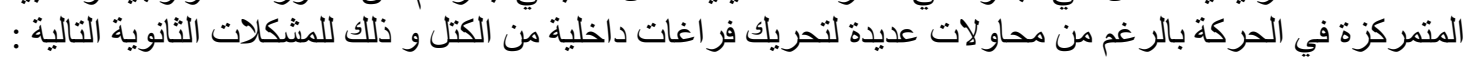

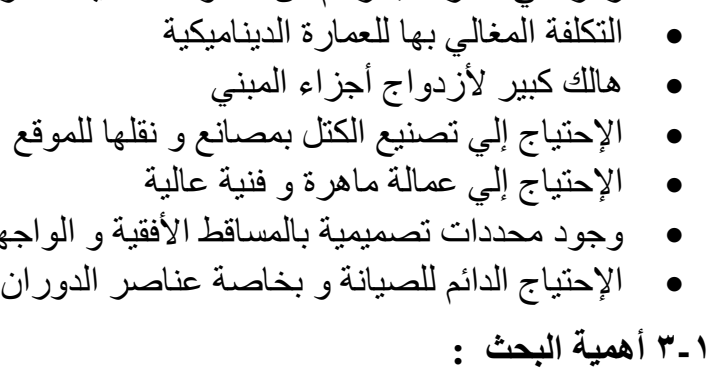

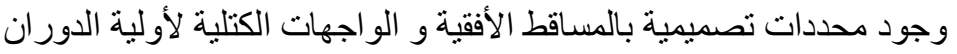

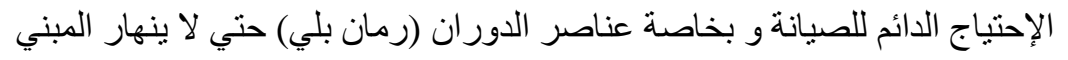

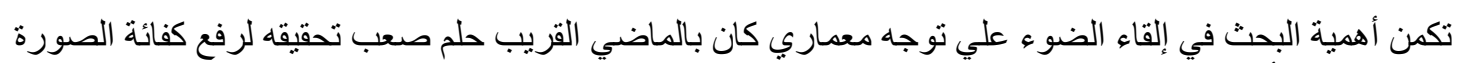

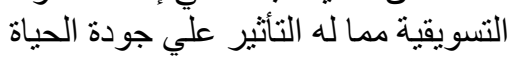




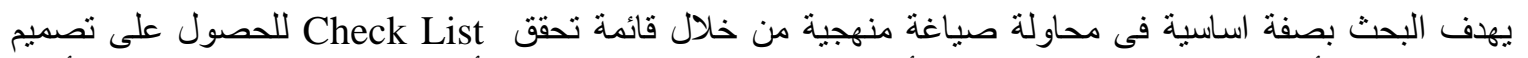

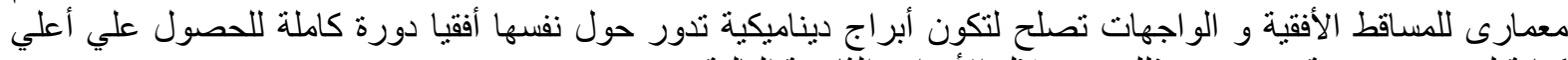

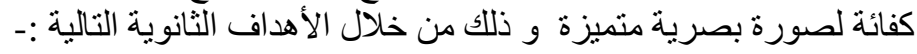

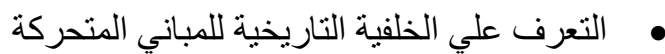

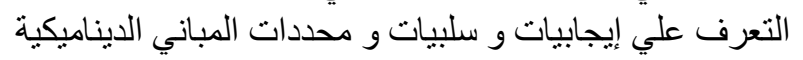

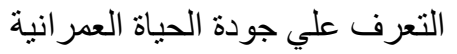 التعرف علي الصورة البصرية للمدينة

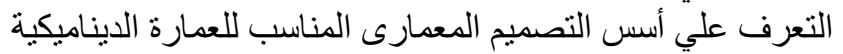

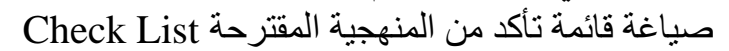

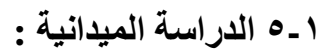

بالتفكير التقليدي يؤدي إلي تواجد الحركة بالعمارة في المباني العامة المتعلقة بجمهور مثل فنادق رأسية - أبراج إدارية مجمعة لثنركات كبيرة -

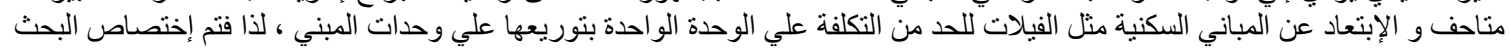

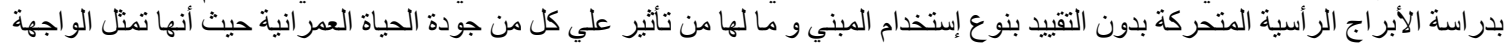

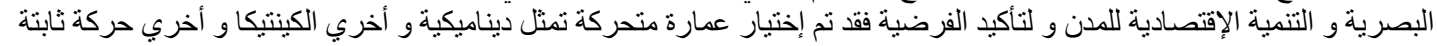

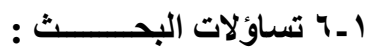

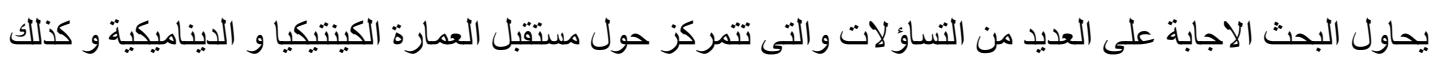

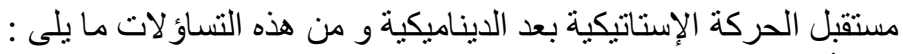

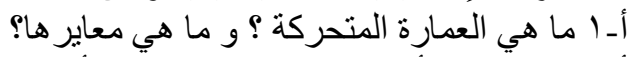

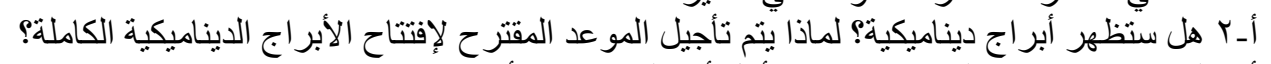

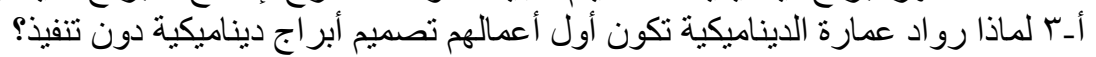

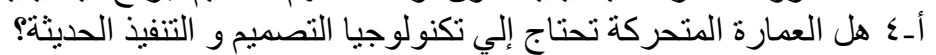

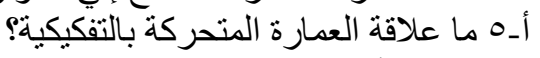

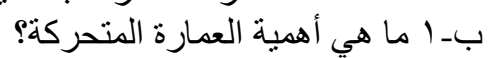

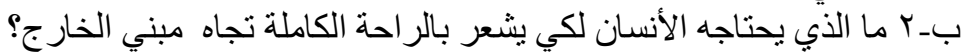

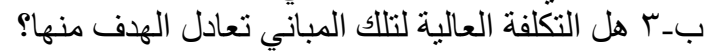

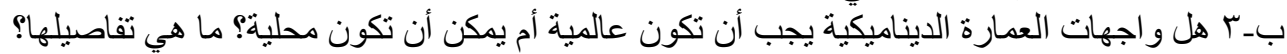

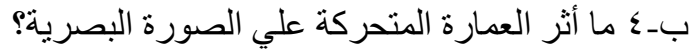

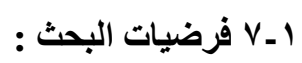

يرتكز البحث على الفرضيات الأربعة التالية وهى :

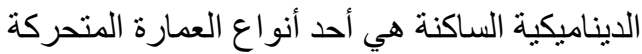

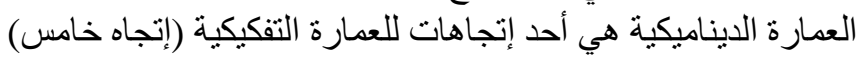

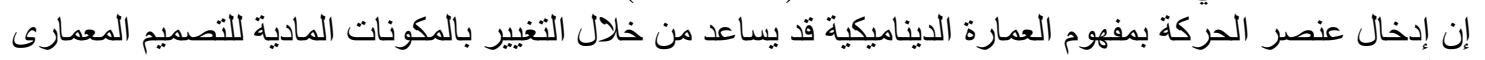
وبالمزيد إنخال

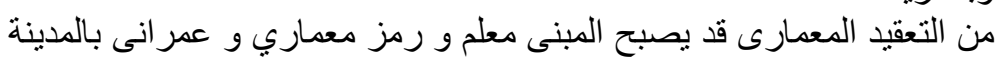

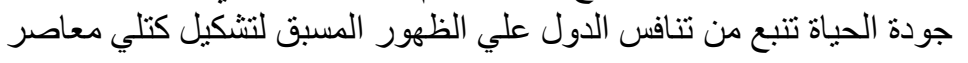

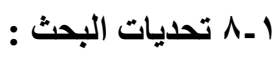

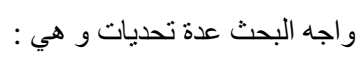

ندرة المر اجع و الأبحاث التي تختص بالثفاصيل و الثقنيات الخاصة بمجال البحث عدم إتمام برج حتي الأن مكتمل ديناميكي متحرك 1 9 منهجية البحث : 
البحث يتكون من جزئين الأول نظري و فيه ينم عرض التعاريف المتعلقة بموضو ع البحث و الخلفية التاريخية للعمارة

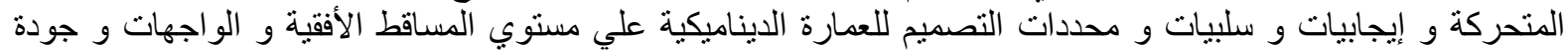

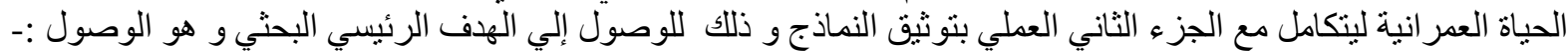

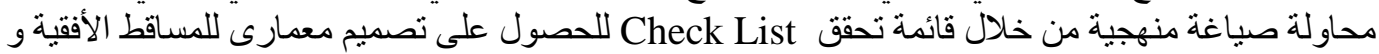
الو اجهات تصلح لتكون أبر اج ديناميكية

$$
\begin{aligned}
& \text { r r - تعاريف و الخلفية التاريخية : } \\
& \text { r-1 } \\
& \text { ז-1 إل علم السكون ( الإستاتيكا ) : }
\end{aligned}
$$

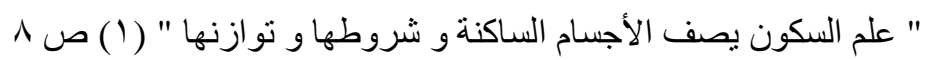

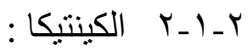

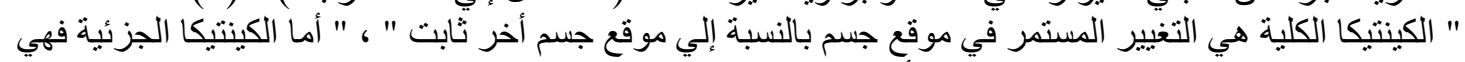

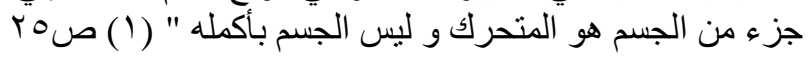

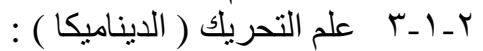

" هو العلم الذي يدرس حركة الأجسام و ما هي القوي و التأثيرات التي تتتج أو تؤثر علي الجسم و تسبب الحركة "

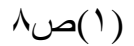

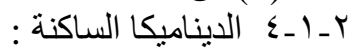

" الحركة تمثل التغيير المستمر في موضع الصورة ، فالتصميم الحركي الجيد بنطلب مئات الطرق لقراعة مضدنة "

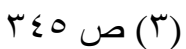
" يعتبر أحد مداخل الديناميكية في العمارة هي مدي قدرة المعماري علي التركيب و التعقيد و التهجين بين العناصر

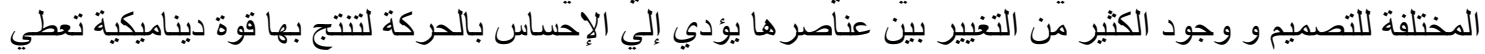

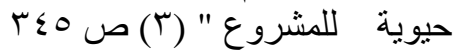

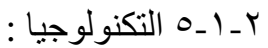

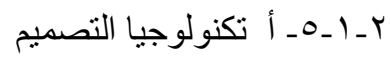

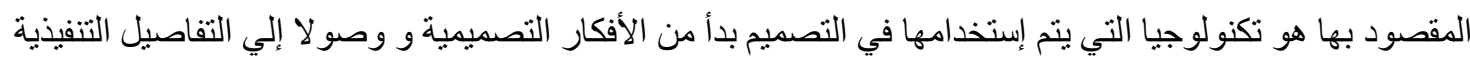
r ـ ـ ـ ـ ب تكنولوجيا التنفيذ المقصود بها هو تكنولوجيا التي يتم إستخدامها في التصنيع بالمصانع و النقل للموقع ثم التركيب المتو افقة مع الظروف

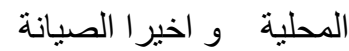

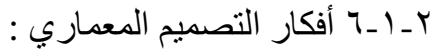

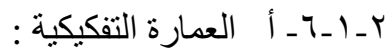
" هي عمارة التكسير و اللاتماثل و اللا ألتساق. عمارة مليئة بالمفاجئات الغير منوقعة تستخدم مفردات العمارة الكلاسيكية

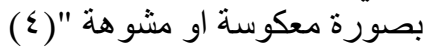

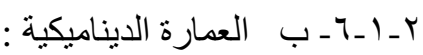

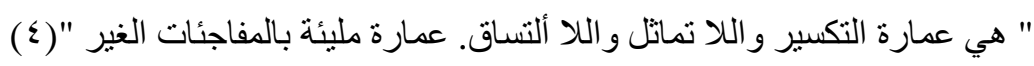

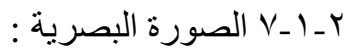
" هي الصورة التي الإنسان يفكر في شكل المدينة من خلالهاو هي تتكون من خمسة عناصر أساسية و منها العلامة المتميزة (o)

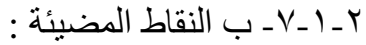


" النقاط المضيئة هي المشاريع الثهيرة عالميا الغير تقليدية داخل المدن و تميز ها من خلال التشكيل الكتلي أو الإستدامة

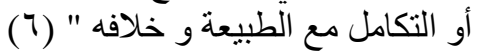

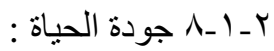

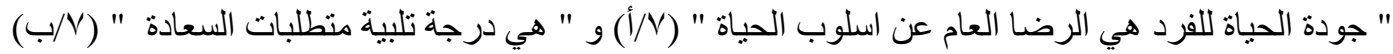

$$
\begin{aligned}
& \text { r r r r r الخلفية التاريخية }
\end{aligned}
$$

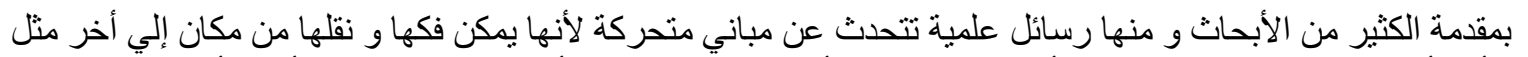

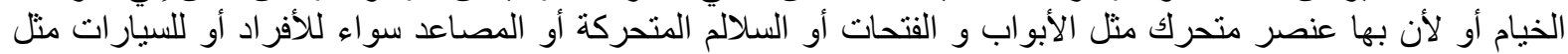

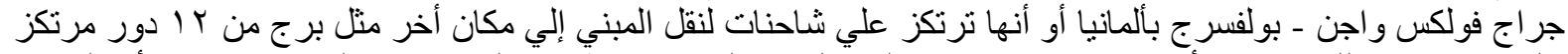

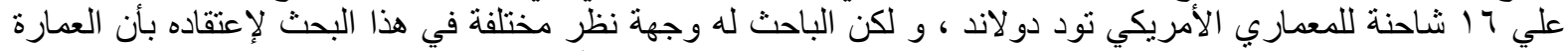
المتحركة هي التي تحتوي علي حركة ذاتية للكتلة كلها لتصب عمارة ديناميكية أ جزء من الكتلة الكنة متحرك لتصبح عمارة كينتيكا

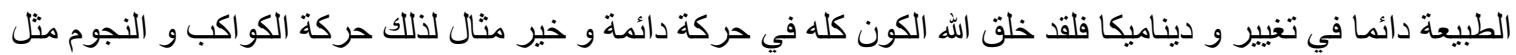

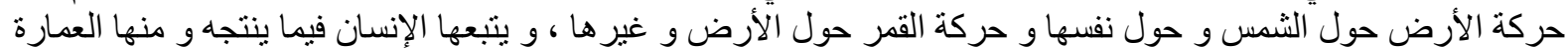

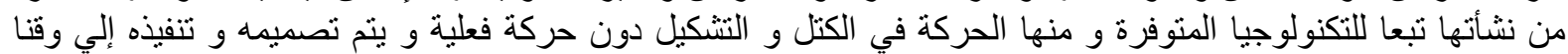

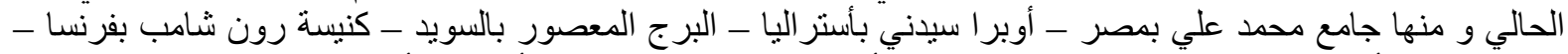

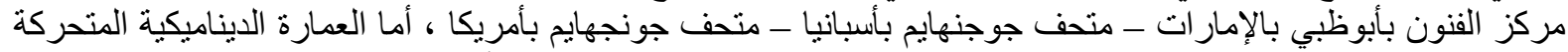

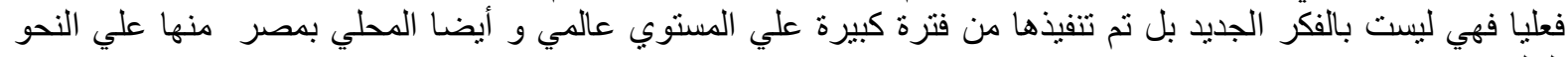

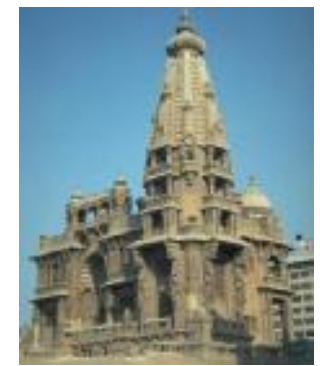

صورة البراز : توضح البرج الاوار بقصر البارون

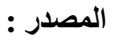
https://common s.wikimedia.org /wiki/File

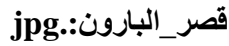

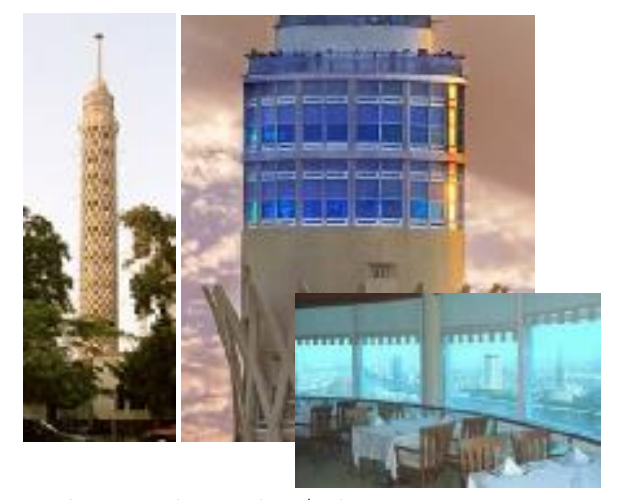

صور Y، r، : : توضح المطعم الدوار بالبرج من الخارج

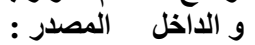

https://www.google.com.eg/search? q = = = = = =

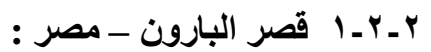

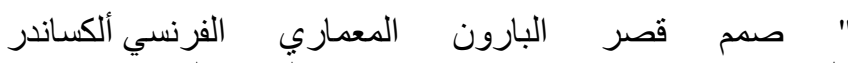

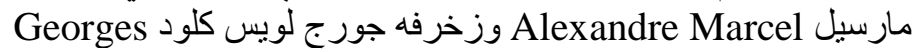

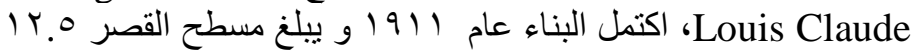

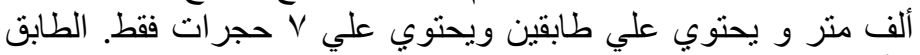

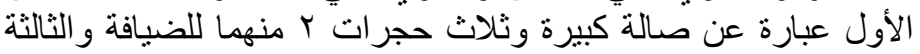

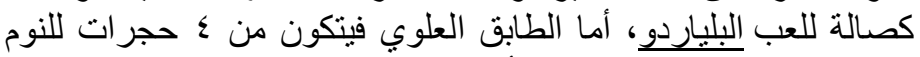

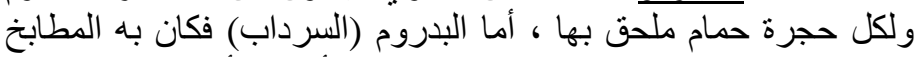

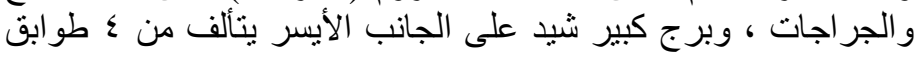

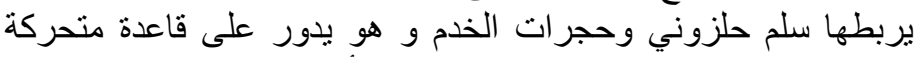

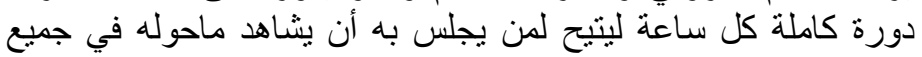

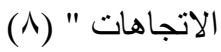

$$
\text { : }
$$

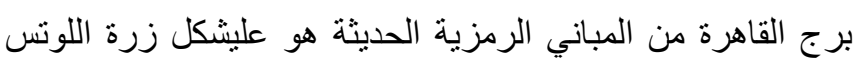

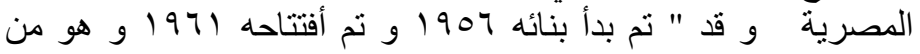

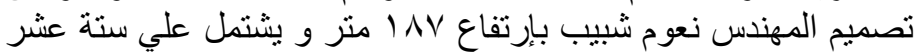

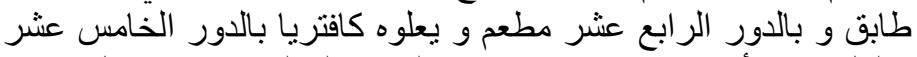

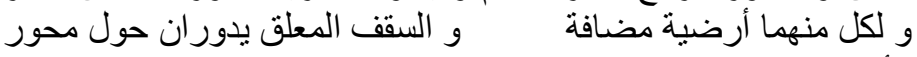

رأسي دورة كاملة " (9) 


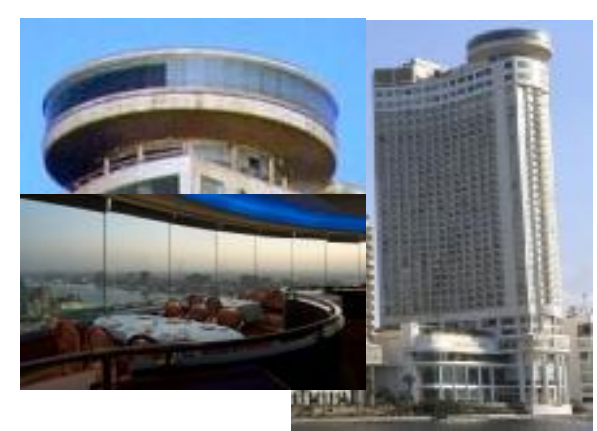

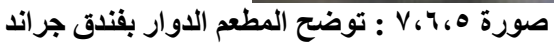

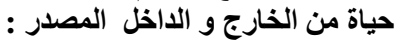

https://rahalat.net/hotel/cairohotels/Gr and-Hyatt-Hotel-Cairo.php

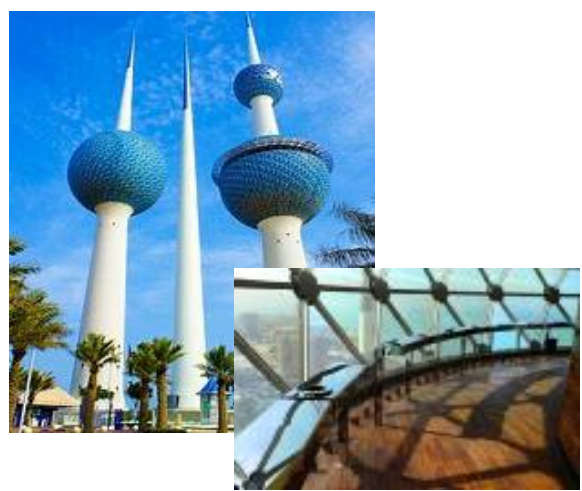

صور ^، 9 : توضح أبراج الكويت من الخارج و الداخل المصدر :

https://ar.wikipedia.org/wiki/أبراج_الكويت :

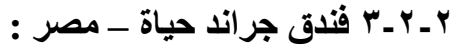

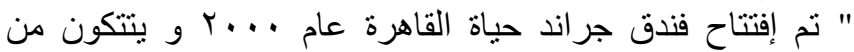

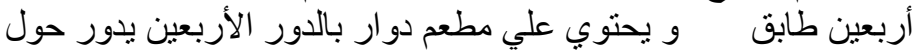

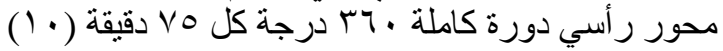

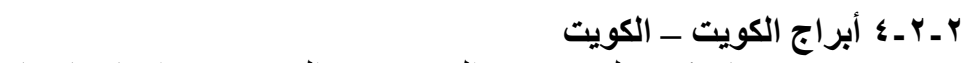

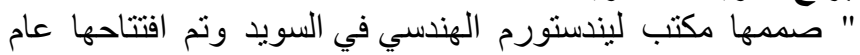

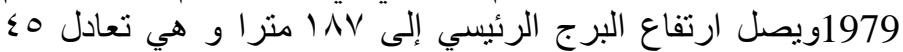

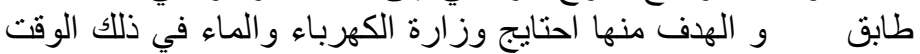

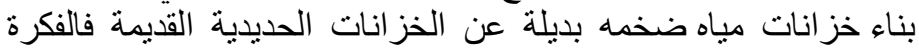

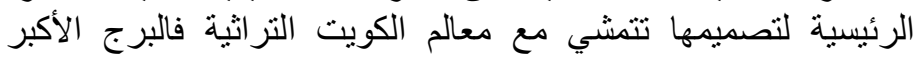

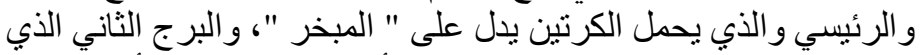

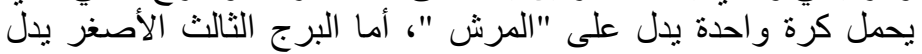

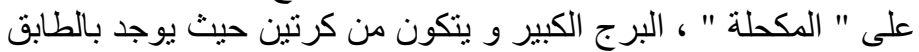

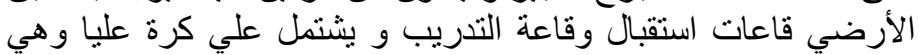

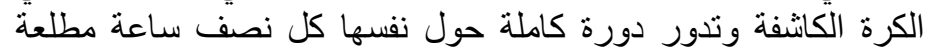

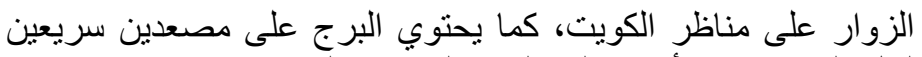

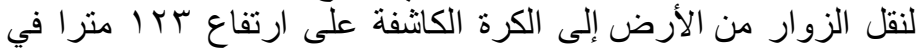

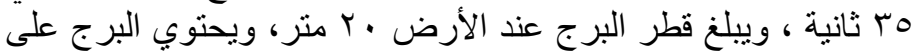

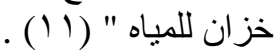

و لكن ما سبق هو عمارة ديناميكية من داخل المبني بدون التأثير علي الكتلة أو الواجهة من الخارج فالو اجهة ثابتة و

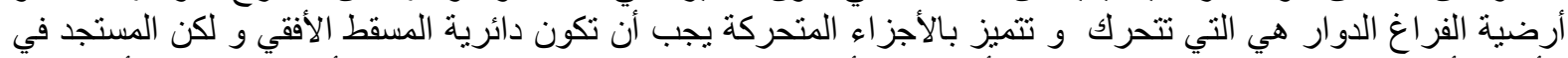

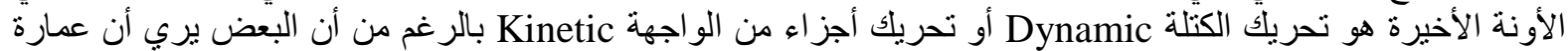

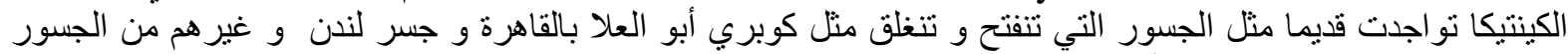
بالرغم - من وجهة نظر الباحث أن الجسور و الكباري ليست بكت بكتل مباني معمارية

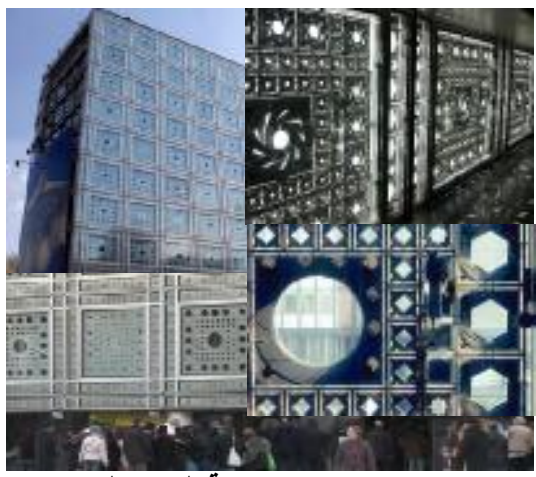

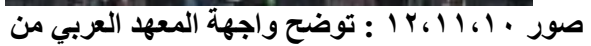

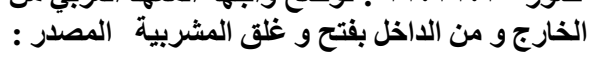
httpps://maktoob.images.search.yahoo.c om/search/images?p=

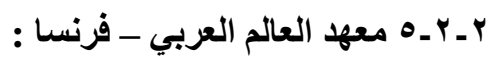

" بينما في العصر الحديث تم تأسيس معهد العالم العربي في باريس

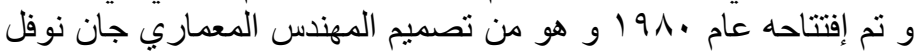

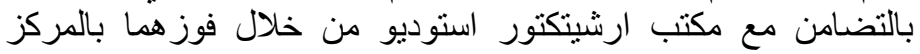

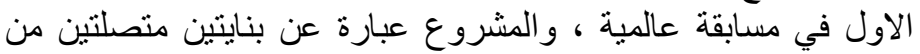

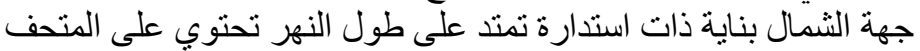

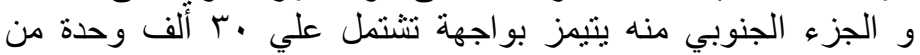

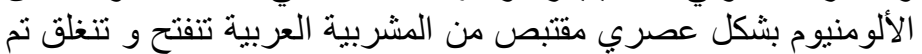

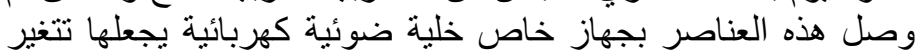

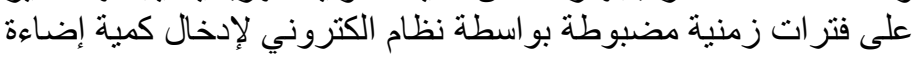

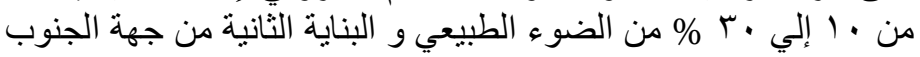

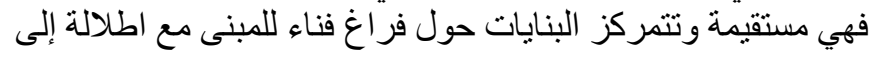


جهة وسط المدينة و في البناية الثانية المكتبة تتكون الفر اغات من احجام مزدوجة الارتفاع تتصل ببرج الكتو الكتب عن طريق

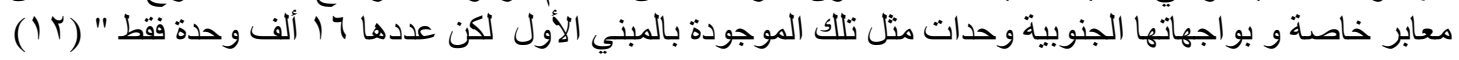

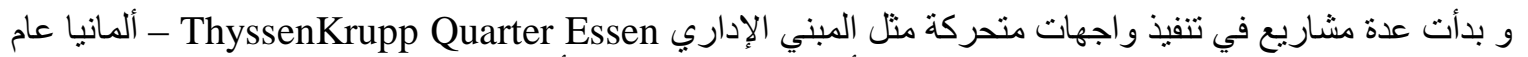

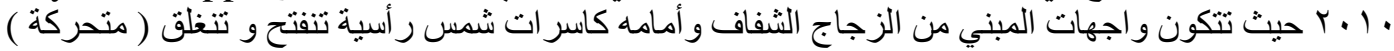
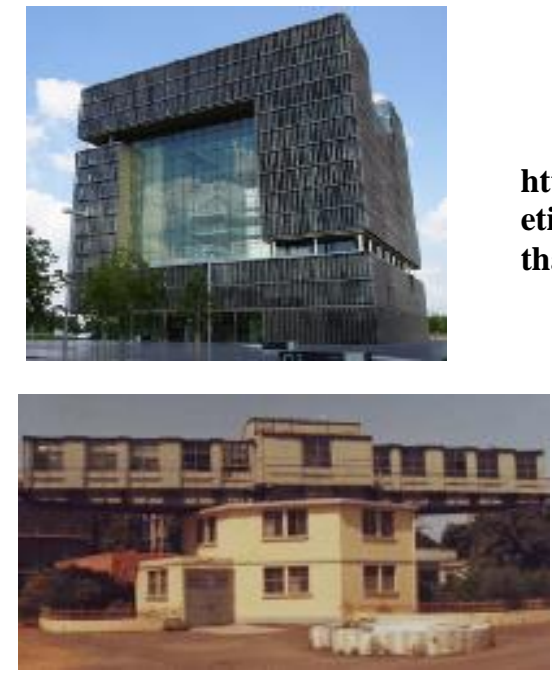

صورة (0) 10 ) : توضح المستثفي الدوار المصدر : http://solarhousehistory.com/blog/2013/ 7/12/freak-houses-mounted-on-turntables

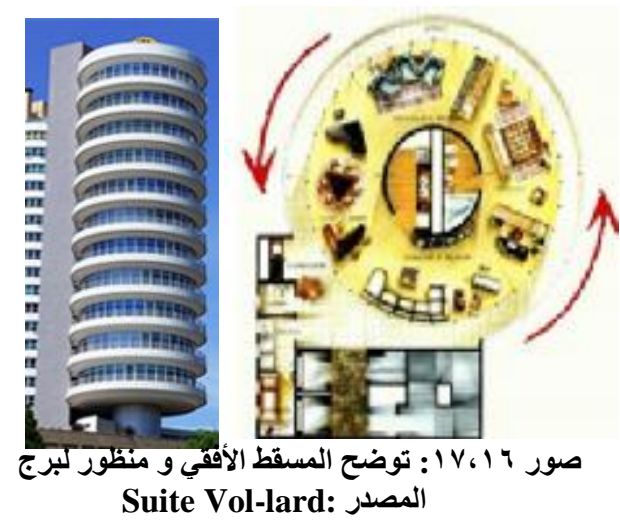

https://en.wikipedia.org/wiki/Suite Volla
صور r I I I 1 : توضح واجهة

ThyssenKrupp Quarter Essen المصدر :

httpps://www.modlar.com/news/212/kin etic-architecture-dynamic-buildingsthat-will-move-you/

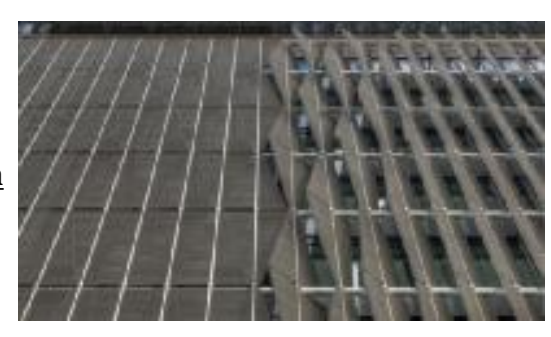

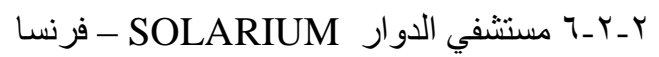

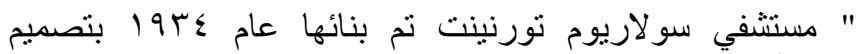

المعماري أندريه فارد Andree Farde بفكرة الطبيب جين سيدمان Jean Saidman

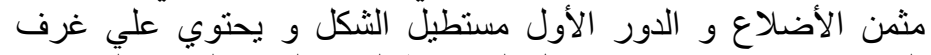

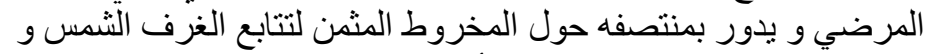

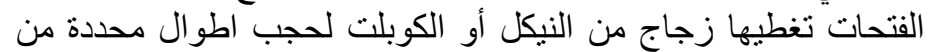

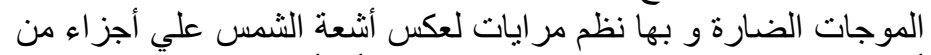

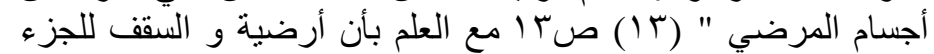
المتحرك و احد بدون تكر ار

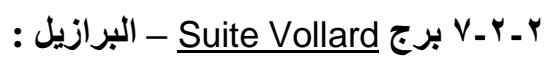

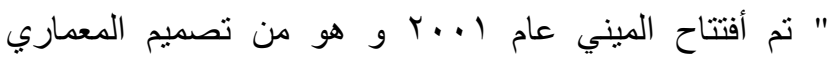
Bruno de Franco •

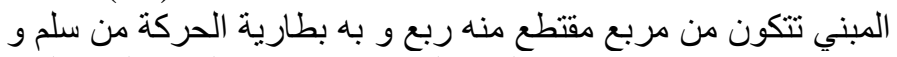

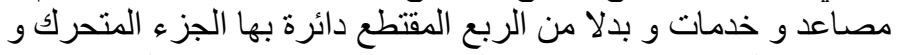

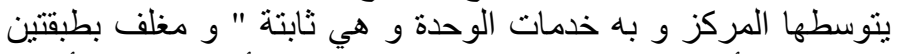

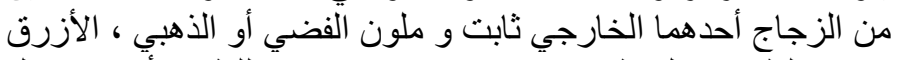

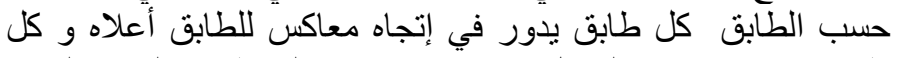

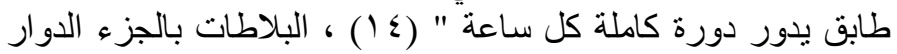
False ثابتة للأرضية و السقف و المتحرك فقط هو أرضية إضافية False Ceiling و Flat ب ـ العمارة التفكيكية

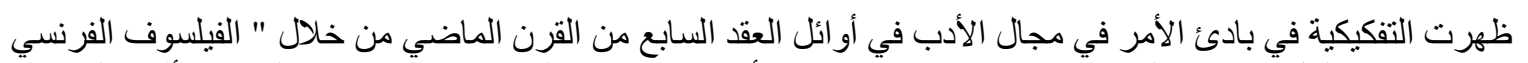

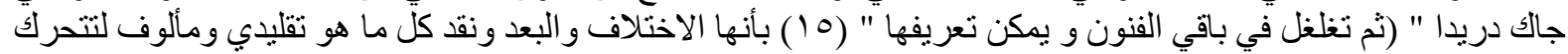

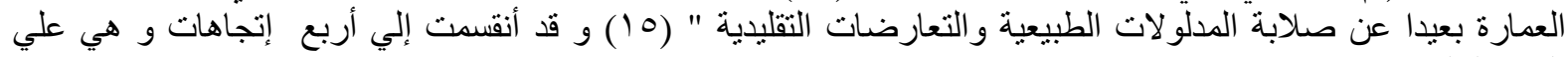

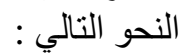


جدول ( ) ) يوضح الإتجاهات الأربعة للعمارة التفكيكية و خصائصها و روادها و أمثلة لها المصدر : الباحث

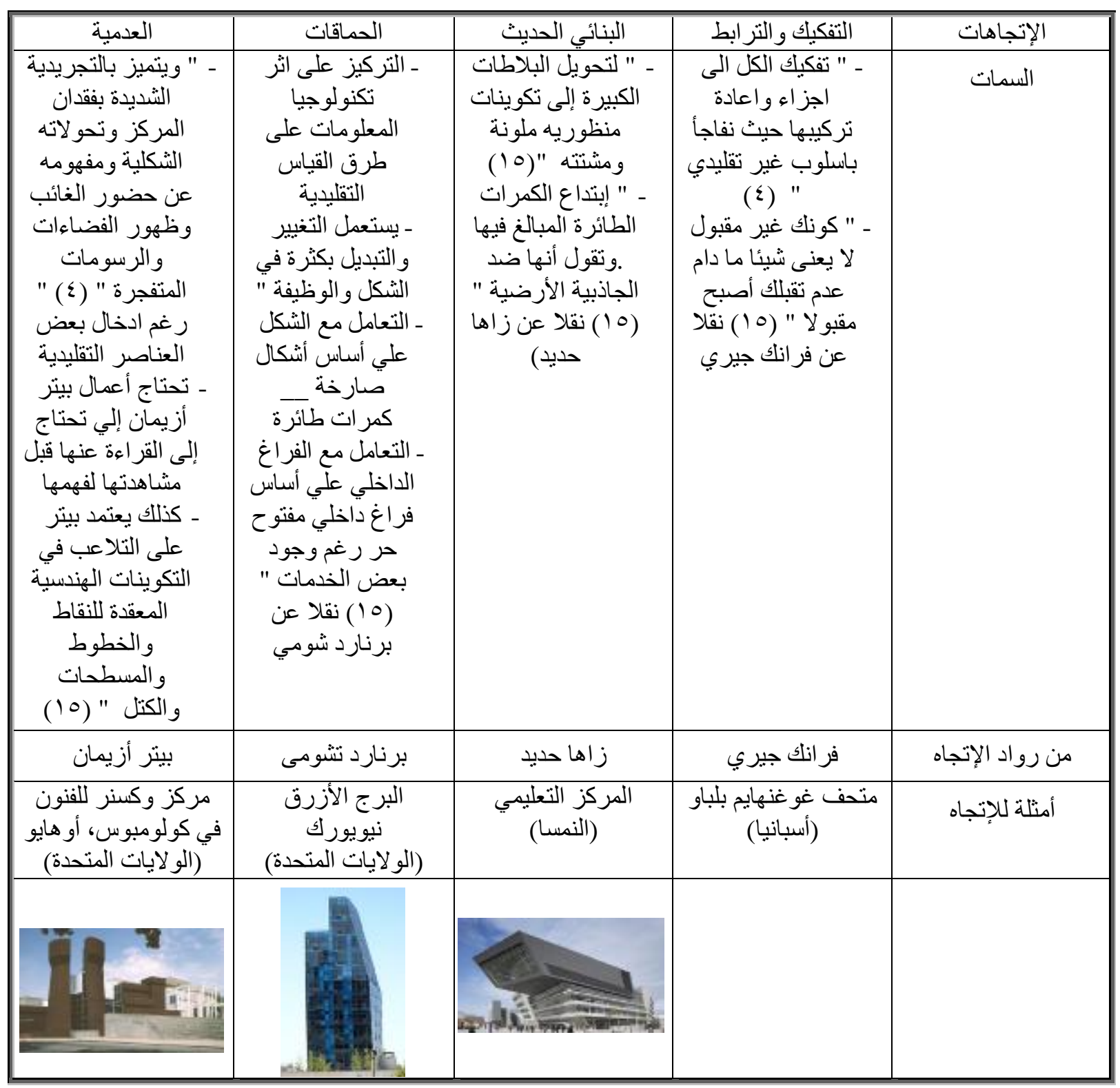

يمكن إعتبار - من وجهة نظر الباحث - أن إتجاه البنائي الحديث للعمارة التفكيكية يختلف فقط عن العمارة المتحركة

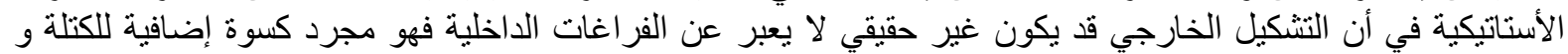

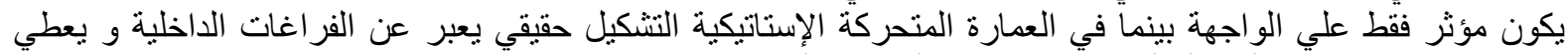

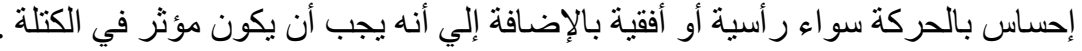

الحركة - من وجهة نظر الباحث - تكمن في إستمرارية الحركة دون دون مفاجأة في إتجاه الحركة فعلي سبيل المثال

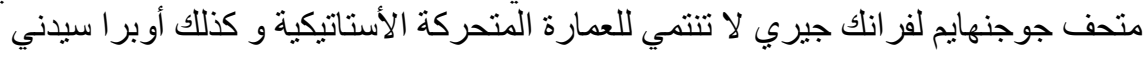

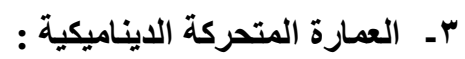

كما قال "كريستوف باودر": "لطالما عُرفت العمارة بأنها ساكنة وثابتة وثقيلة. فعمارة المستقبل ستتكيف ماديا مع احتياجاتنا

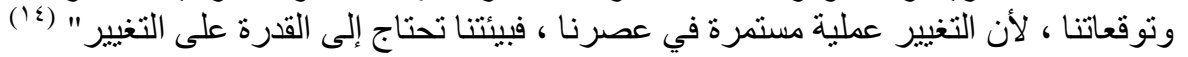




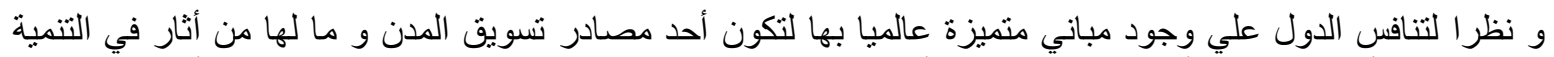

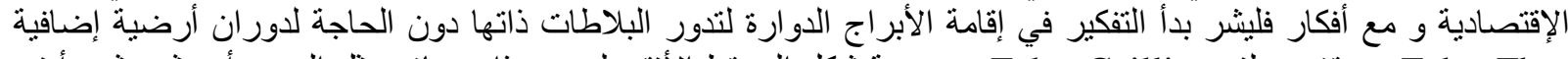
False Flat

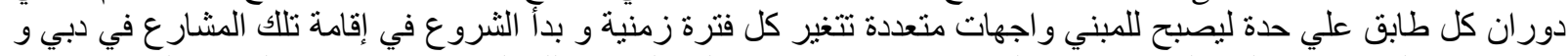

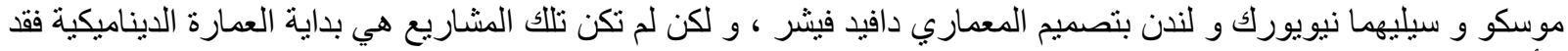

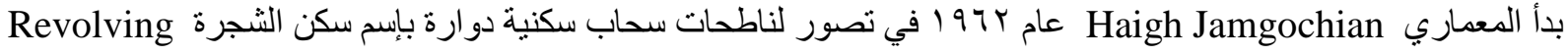

Tree العمارة المتحركة الديناميكية لها إيجابيات و سلبيات و أيضا لها محددات علي النحو التالي :-

$$
\begin{aligned}
& \text { rــ إيجابيات العمارة المتحركة الديناميكية : } \\
& \text { همكن إستخدامها في توليد الطاقة } \\
& \text { سر عة التتفيذ تصل إلي ثناث أيام للدور } \\
& \text { ت تغيير التوجيه للوحدات بصفة دورية التية } \\
& \text { و واجهات متغيرة بعيدة عن الملل لكئل }
\end{aligned}
$$

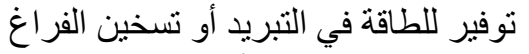

Flat العناصر الإنشائية الرأسية تتمثل في حوائط ثابتة حول بطارية الحركة و الخدمات و البلاطات بدن كمر Slap مرونة عالية في التصميم للمسقط الأفقي

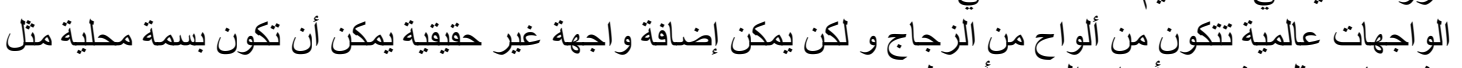

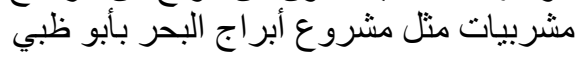

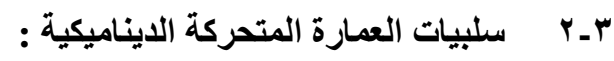

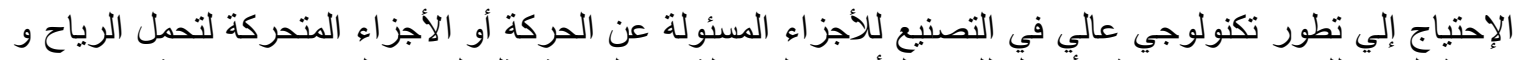

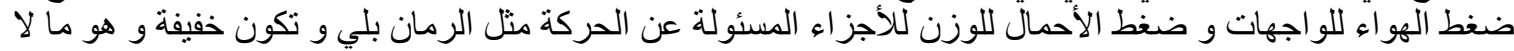
تتو اجد إلا في مثل المواد النانوية التكلفة العالية

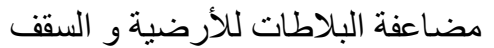
صعوبة في التوصيلات للتجهيزات ( المواسير و الكابلات و الأسلاك الكهربائية و مخارج التكييف )

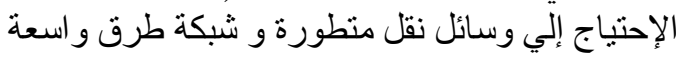

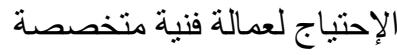

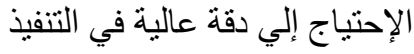

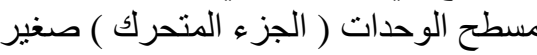

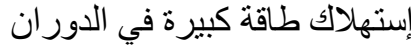

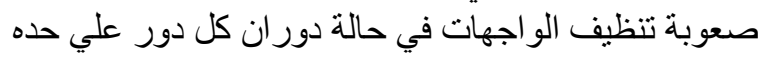

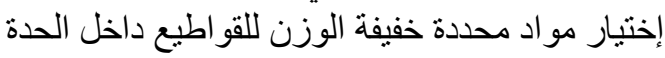

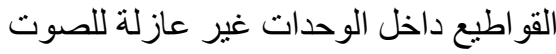

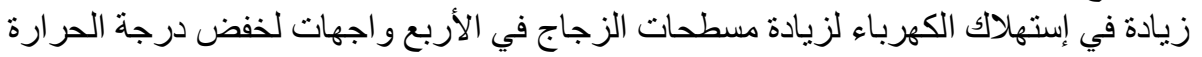

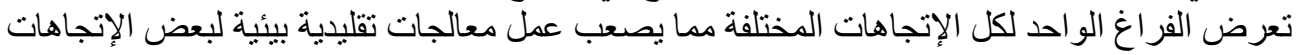

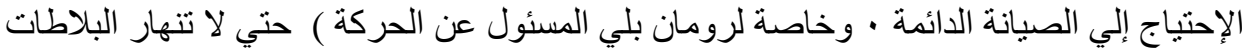
مقلقة للحالة النفسية لبعض الثخان الثخصيات

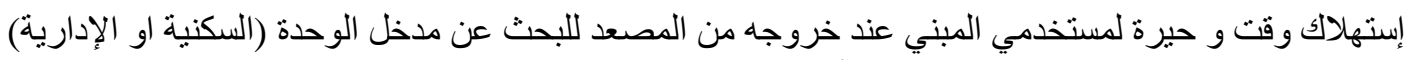

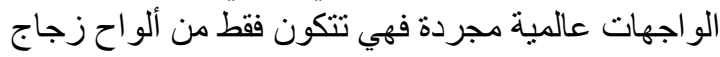

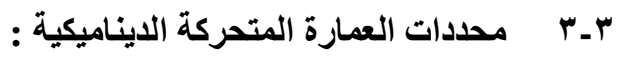
تصميميا يجب وجود حواف بارزة أو محدبة في مناطق بالمساقط الأفقية حتي تظهر الحركة 
• موقع مو اسبر التغذية و الصرف و مخارج التكييف بوسط الجزء الثابت من المبني ( وسط المبني )

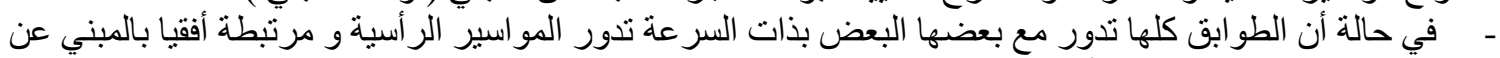
طريق وصلات للمدادات الأفقية

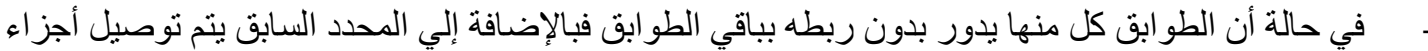

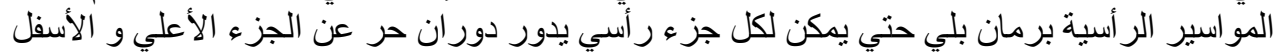

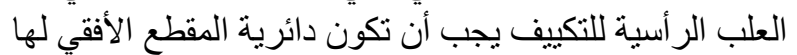
بطارية الحركة من مصاعد و السلالم بكل أنو اعهاو الطرقة الطئة أما مداخل الوحدات ثابتة و يجب أن تثو اجد في الجزء

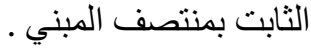
الحائط الإنشائي حامل المبني (Cheer Wall) بسمك و حجم كبير و يجب أن يكون دائري المسقط الأفقي لأنه

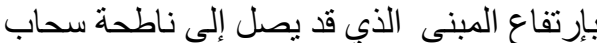
بحمل كل من الجزء الثابت من الّبلاطات ( الطرقة ) و الجزء الجّ المتحرك من البلاطات ( الوحدات ) لتفادي تلف العامود (إلتو اء) وجود فاصل بين الأدوار مثلث الثنكل للقطاع الر أسي لها بحيث يكون صغير عند مركز المبني و الإرتفاع الكبير عند خط الواجهة لحمل البلاطة الطائرة (Cantilever) بلاطة الجزء الثابت بمنتصف المبني يجب أن تكون بسمك كبير و تحتوي علي كمر ات ر ابطة قوية لربط الحائط

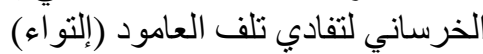

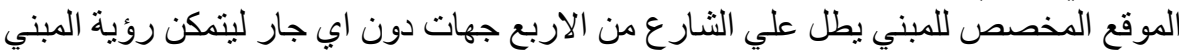

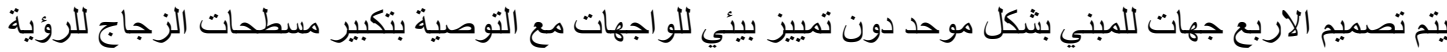

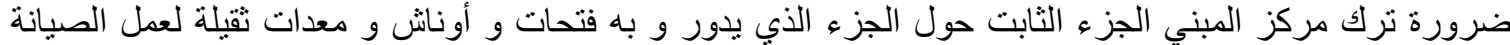

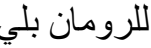
ت • ضرورة التصميم علي موديول يختلف شكله تبعا لنوع الحركة و شكلها

الإبداع في العمارة الديناميكية في التشكيل الكتلي أم الحركة ذاتها ؟ بمعني أستطو انة مجردة متحركة تدور حول نفسها هي التي

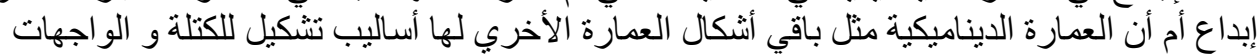

ع ـ العمارة المتحركة إستاتيكيا

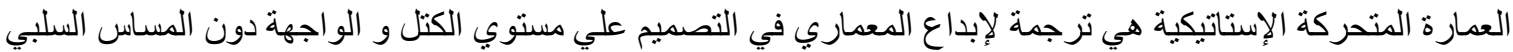

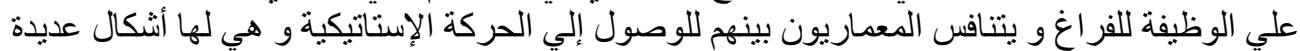

\section{ـ ـ ا 1 أشكال العمارة المتحركة إستاتيكيا : \\ أـ " وفقا لثكل الحركة في الفراغ}

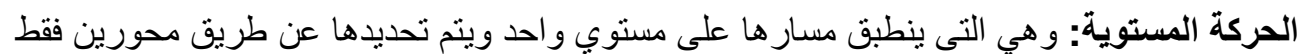

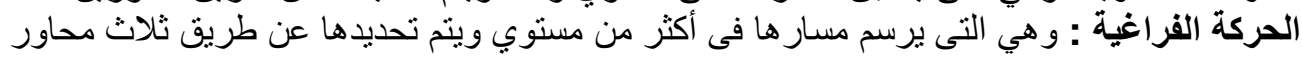

$$
\text { ب- وفقا لشكل مسار الحركة }
$$

الحركة فى خط مستقيم : التى ترسم نقاط الجسم فى مسار ات خطية مستقيمة متو ازية ومنطابقة. وتسمى بالحركة الإنتقالية المية

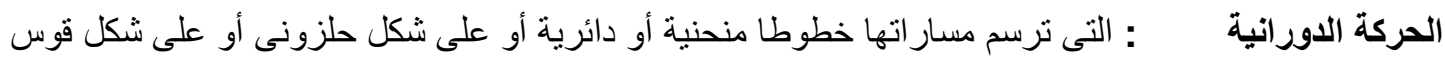

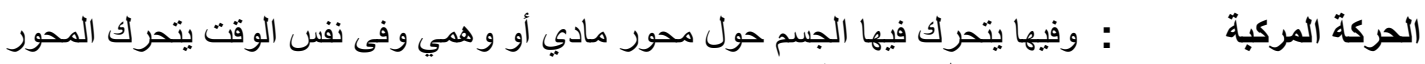
حركة انتقالية فى خط مستقيم تــ وفقاً لعلاقة التغير فى المسافة بالزمن الحركة المنتظمة: و هي التى يقطع فيها الجسم مسافات متساوية فى أزمنة متساوية أي أن معدل التغيير فى المسافة ثنابت ويساوى صفر 
الحركة المتغيرة :و هي التى يقطع فيها الجسم مسافات غير منساوية فى ازمنة المتساوية وتنقسم الى ما يلي:

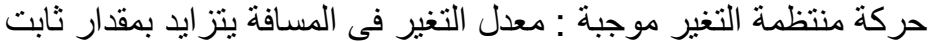

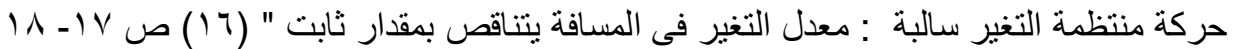

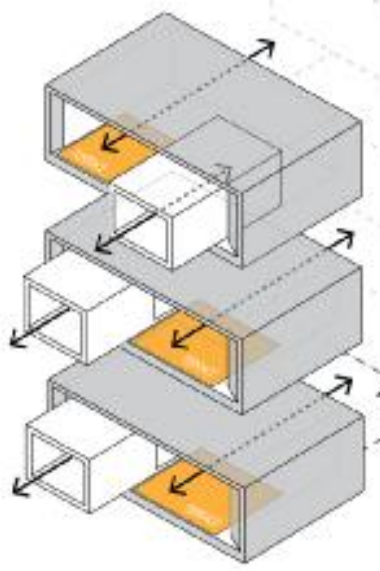

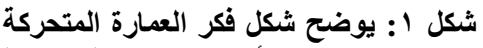

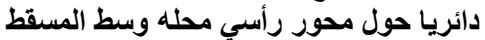

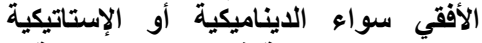

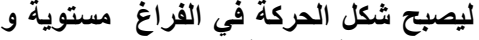

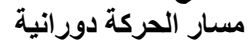

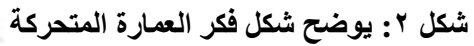

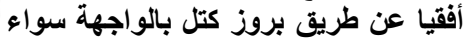

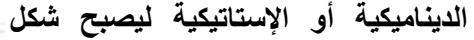

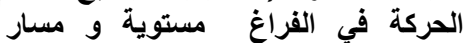

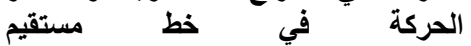

https://www.archdaily.com/522 344/sharifi-ha-house-nextoffice

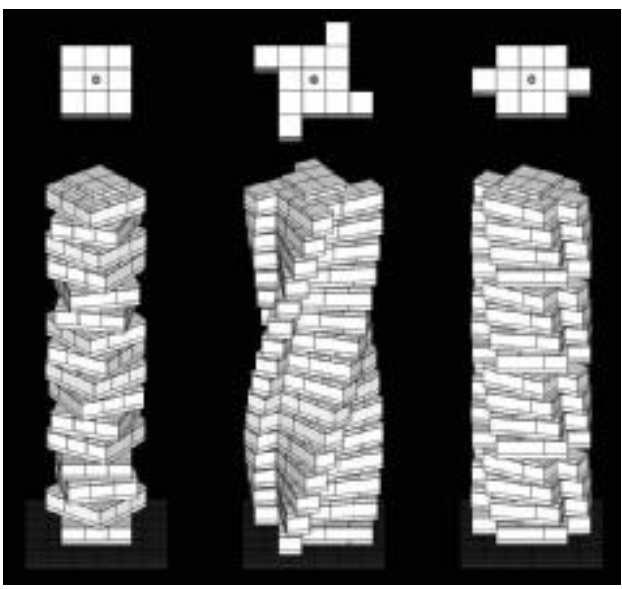

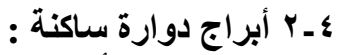
تم تنفيذ عدة أبراج علي هيئة أبئة أبرج دوارة حول مركز أفقي علي مستوي المساقط الأفقية أو حول محور رأسي علي مستوي الوجهة كما في الجدول التالي و هي ساكنة الحركة دولة هرك جدول ("ا) يوضح بعض الأمثلة للأبراج الدوارة ذات الحركة الساكنة المصدر : الباحث

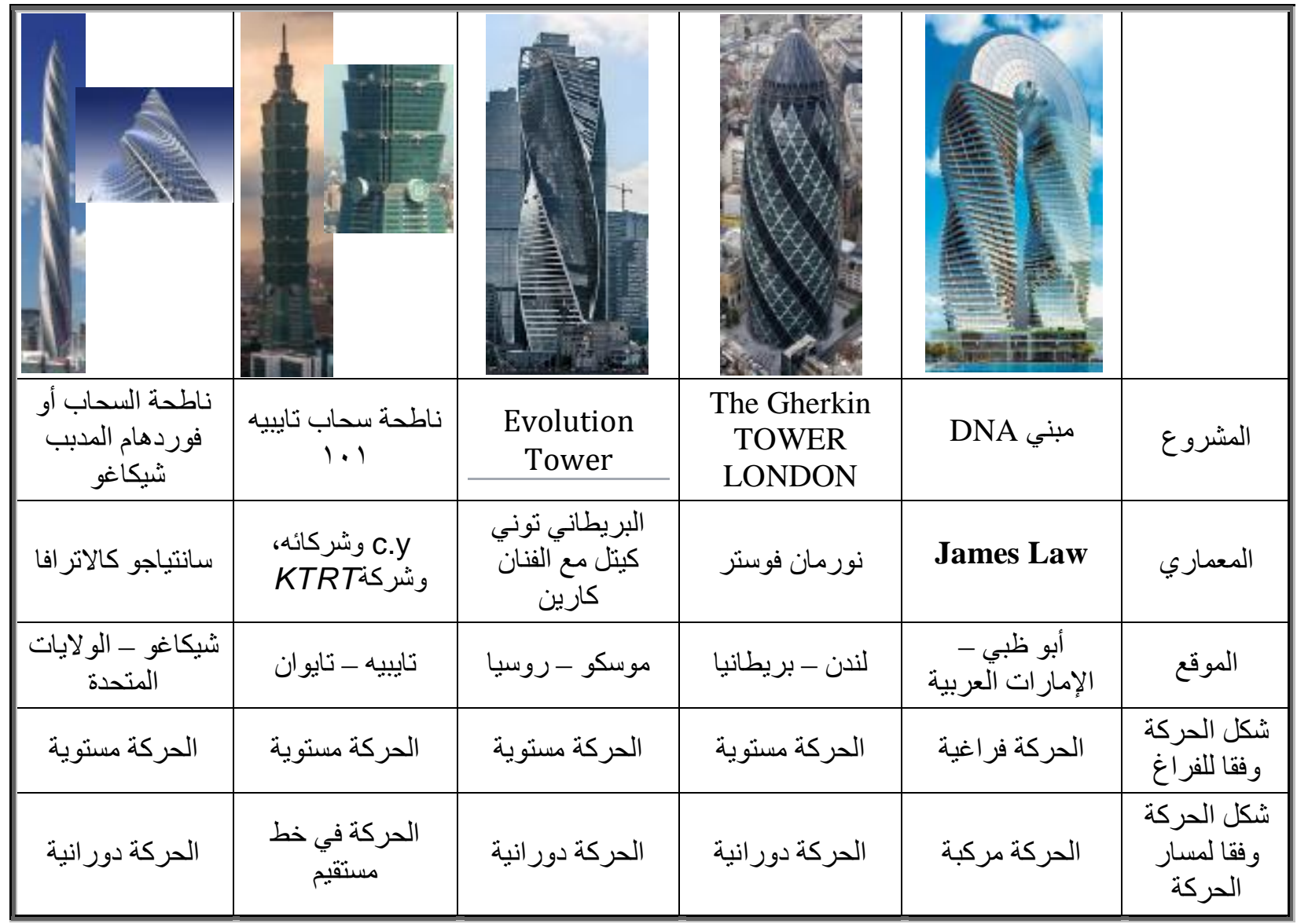


من الجدول السابق أمثلة للمباني الدوارة الساكنة و لكن هل هي متحركة ، فمن وجهة نظر الباحث ـ أن الحركة الساكنة هي مباني بها إحساس الحركة - إنسيابية في الحركة الحئ

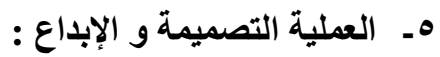 \\ ع ـ ا العملية التصميمية للمبني :}

التصميم المعماري هو عملية معقدة لها طبيعتها الخاصة و لفهم التصميم و الابداع المعماري سيتم البداء بتعريف وشرح بطبيعة التصميم المعمارى و العملية التصميمية ثم بيان مر احل التصميم المعماري وكيف يمكن للمصمم تحقيق الابداع المعماري التصاي

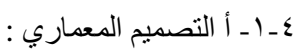

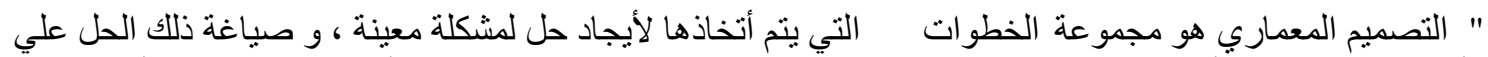

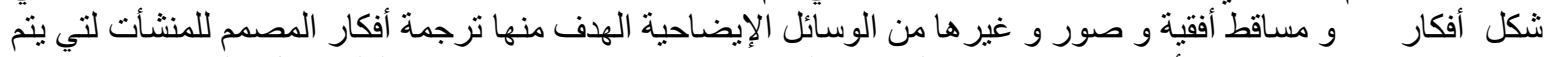

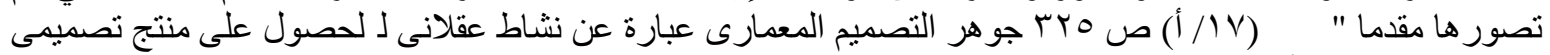

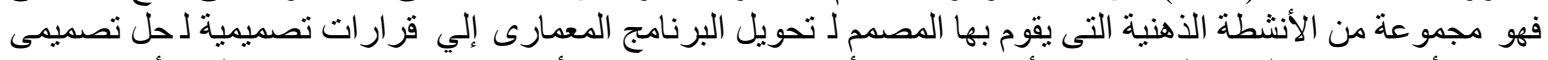

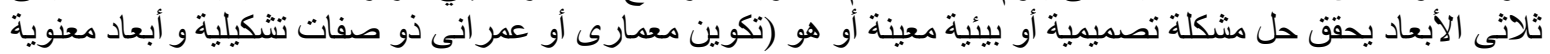

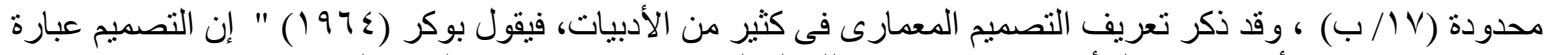

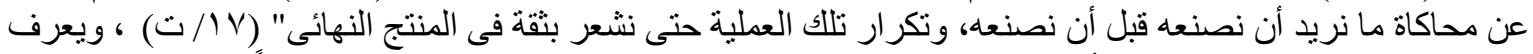

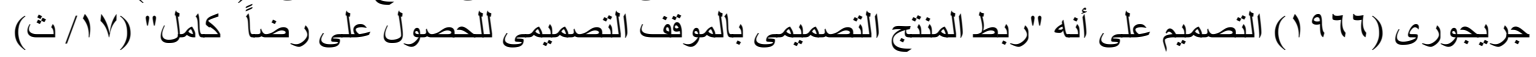

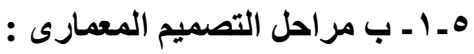

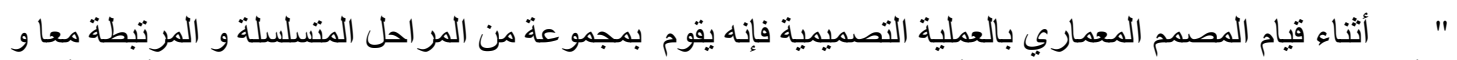

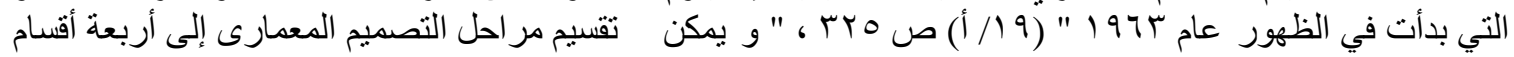

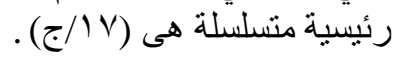

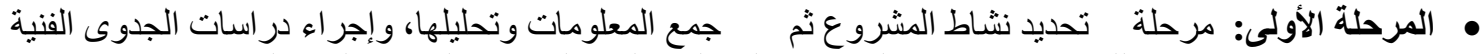

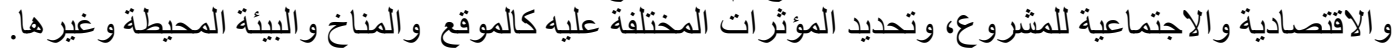

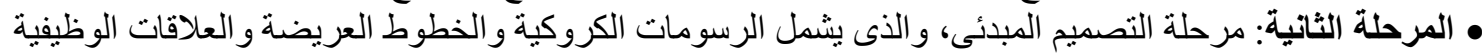

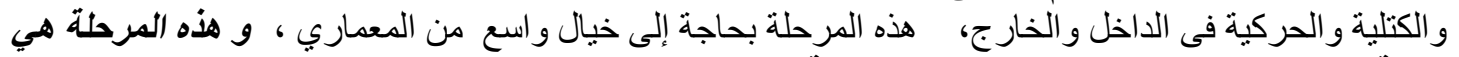

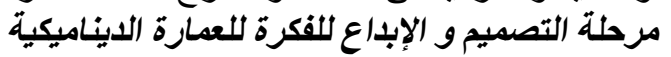

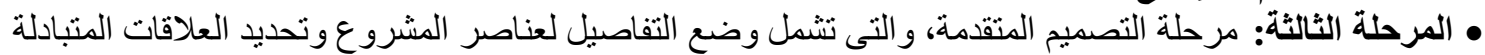

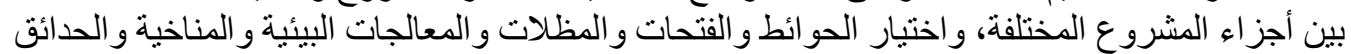

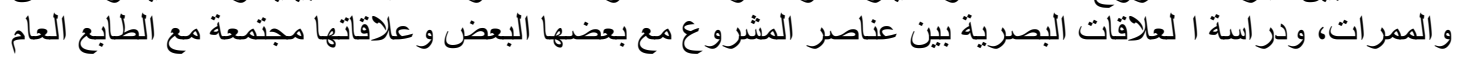

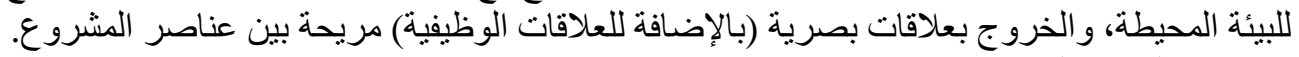

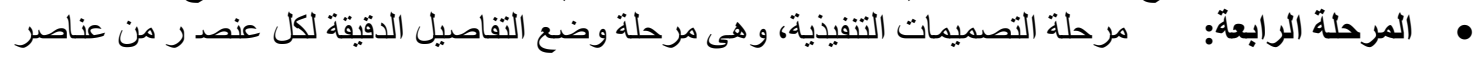

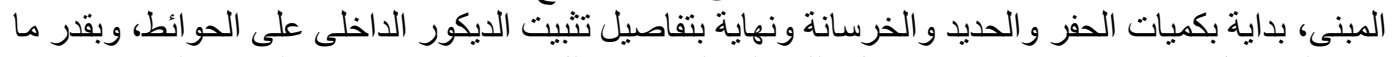

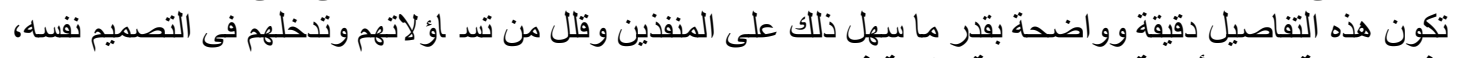
هذه المرحلة لا تقل أهمية عن المرحلة الثانية في الإبداع 


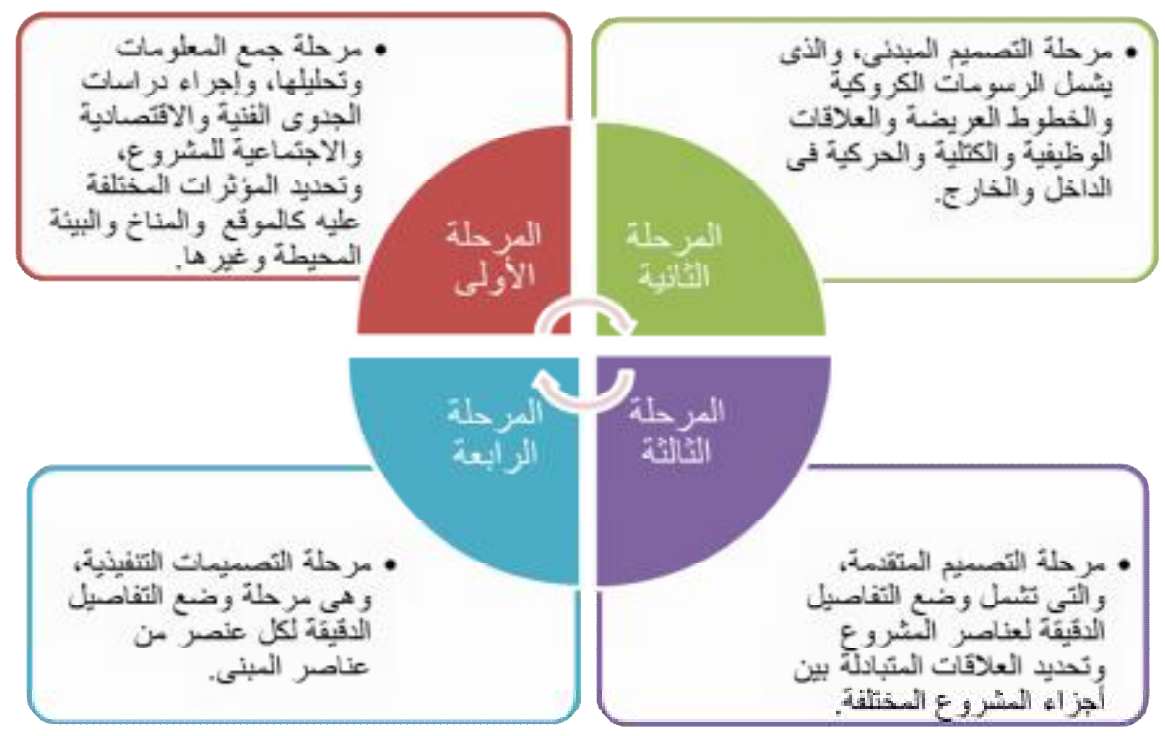

شكل ؟ّ: يوضح مراحل التصميم المعماري المصدر : الباحث

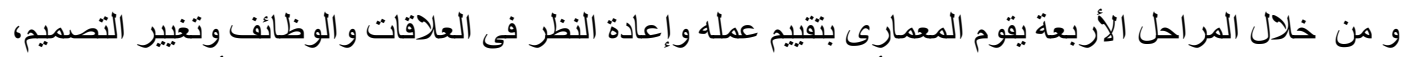

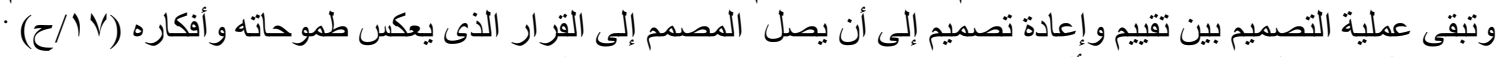

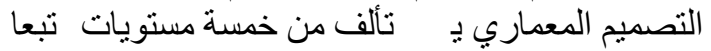

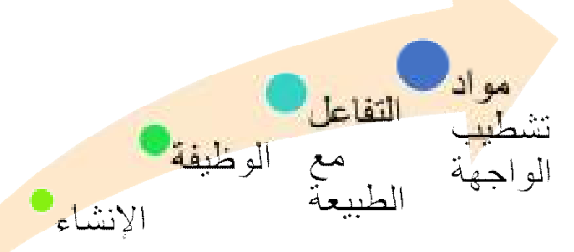

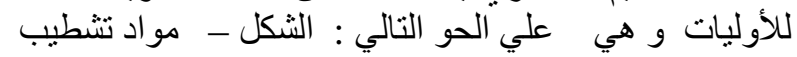
15 شكل ؛ : يوضح أوليات مستويات التصميم المعماري المصدر : الباحث

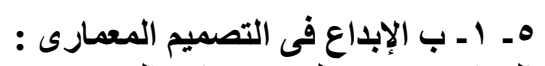
العمارة فن يختلف عن باقي الفنون فهو فن إنتفاعي يعمل علي تشكيل كت لي مع تصميم داخلي يحقق إحتياجات

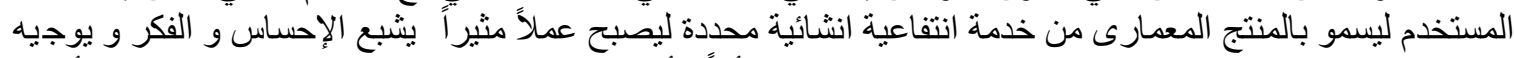

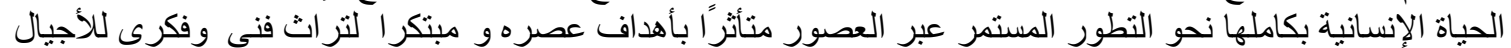

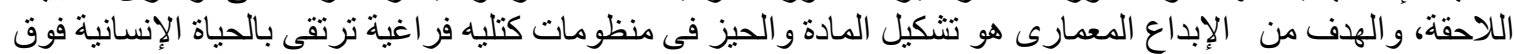

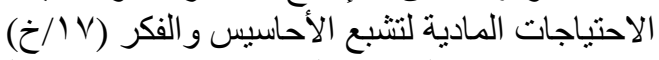

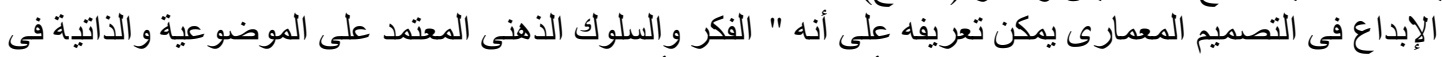

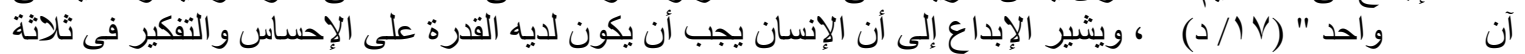

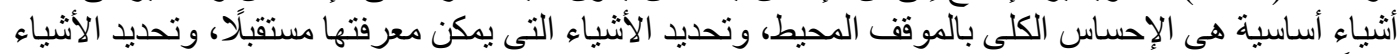

وفيما يلى مجمو عة من العو امل تؤدى إلى السلوك الإبداعى عند المصمم المعمارى:

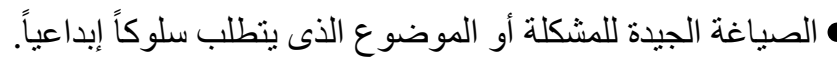
• وضع إستر اتيجيات محدودة لمو اجهة المشكلة. • أبتكار أفكار ليس لها مثيل سابق. • تجنب النقد فى المر احل الأولى لصياغة الأفكار. •تجنب الخوف من حدوث أخطاء. • القدرة على الحكم على مدى ملائمة الأفكار للموقف. 
وقد أوضحت در اسات علم النفس أن قدر ات الابتكار لاى الثخص إنما تندرج ضمن العمليات العقلية التتعبية (Divergent Mental Operation)

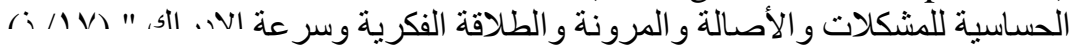

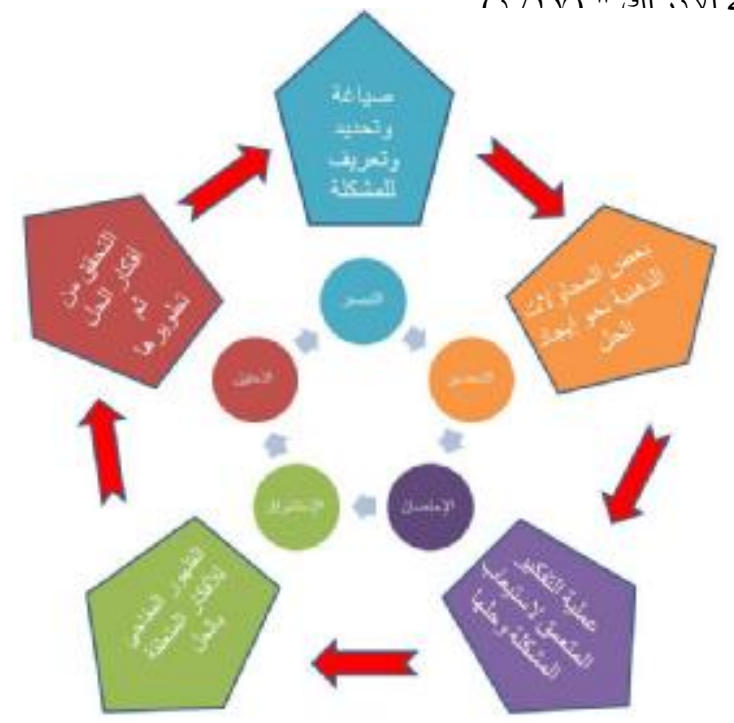

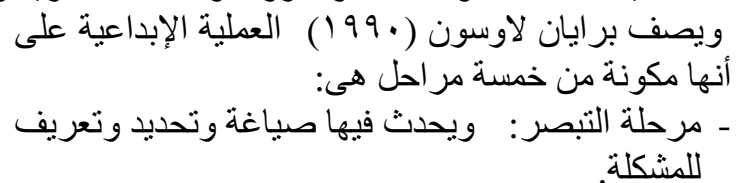
- مرحلة التحضير: وتحدث فيها بعض المحاو لات

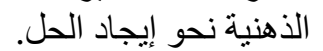

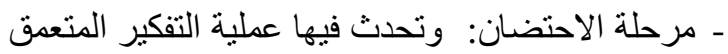
لاستيعاب المشكلة وحلها.

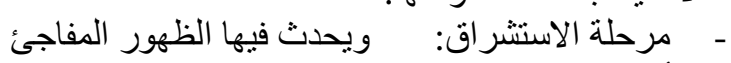

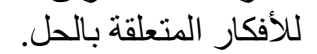
- مرحلة التحقيق: ويحدث فالحلث فيها التحقق من أفكار الحل ثم تطوير ها.

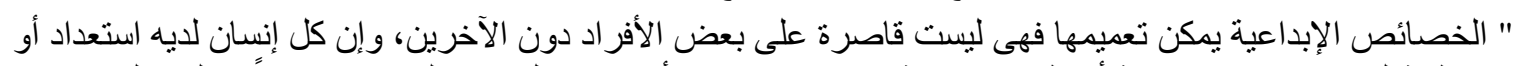

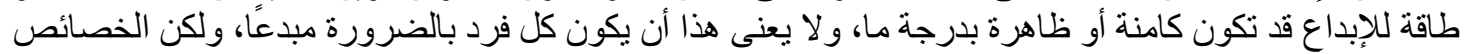

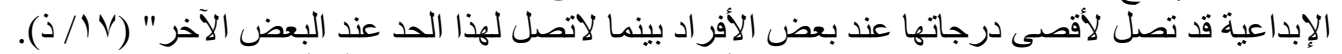

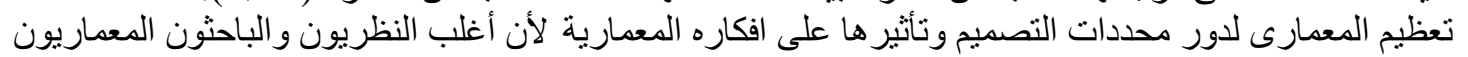

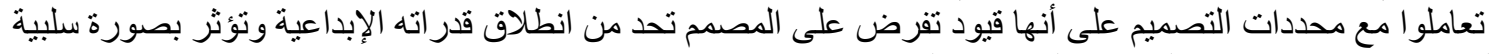
على إنتاجه من تصميمات المبانى و الفر اغات النهات المعمارية.

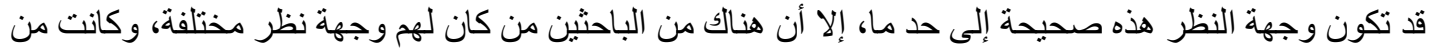

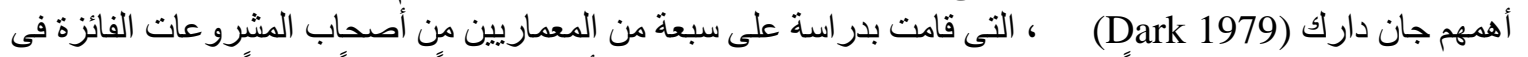

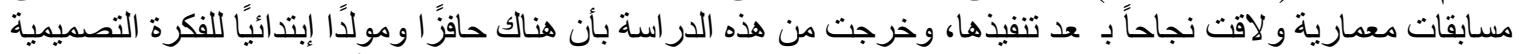

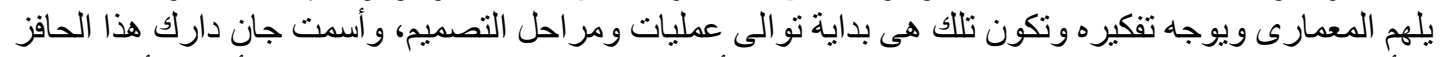

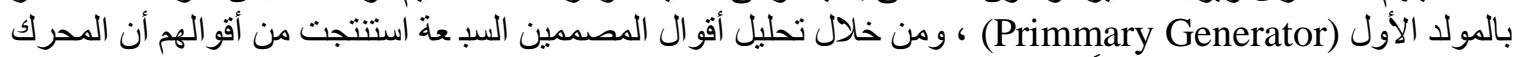

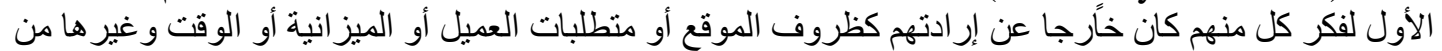

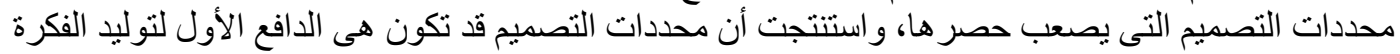

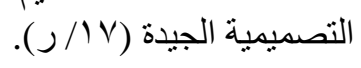

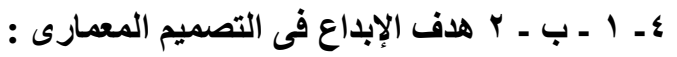

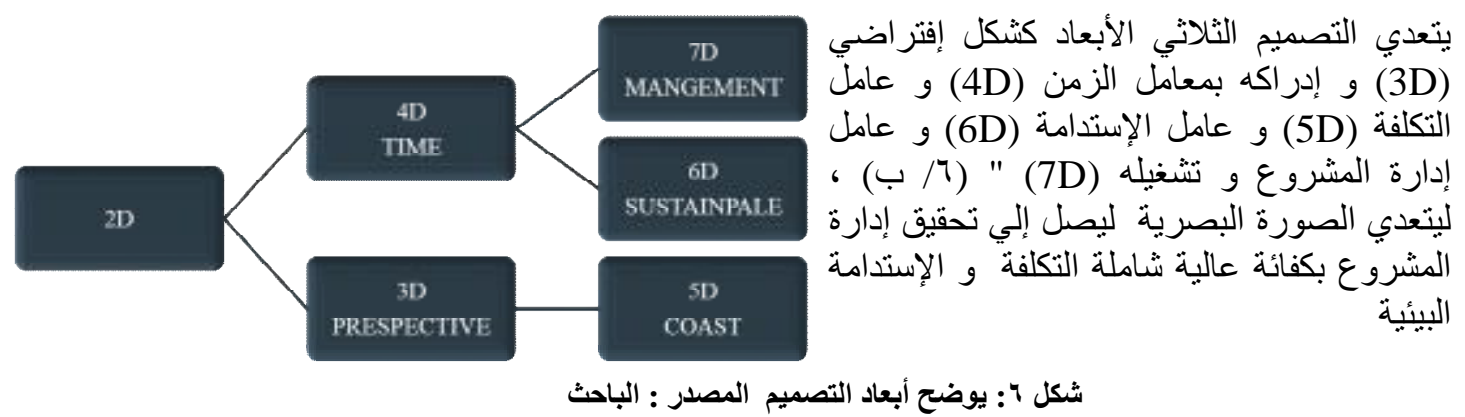




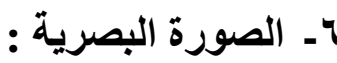

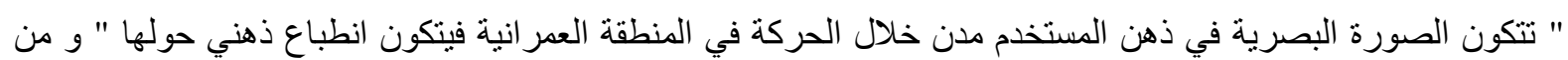

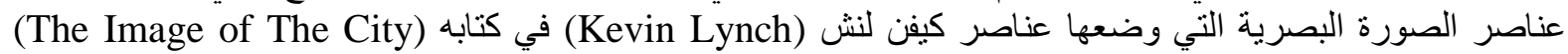

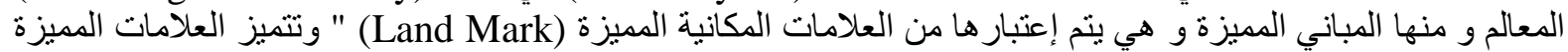

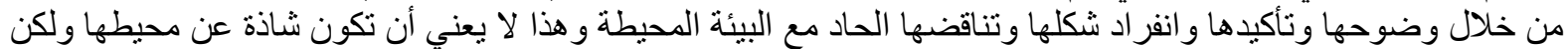

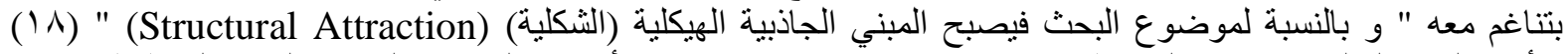

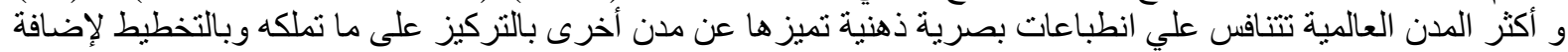

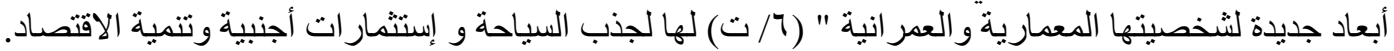

ד-1 النقاط المضيئة للمدن :-

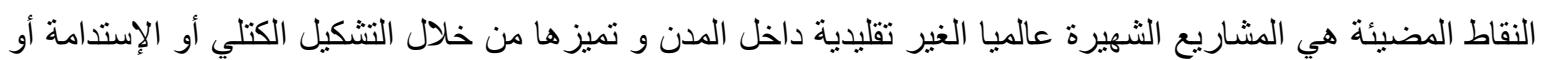

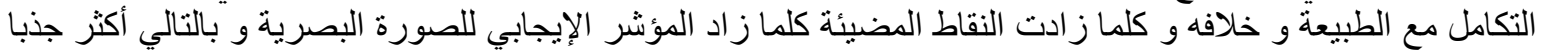

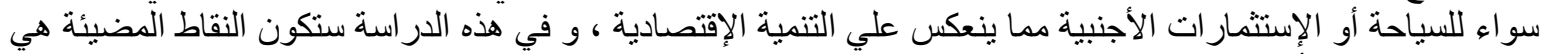

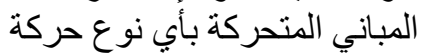

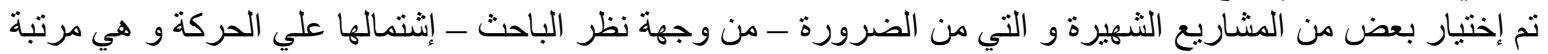

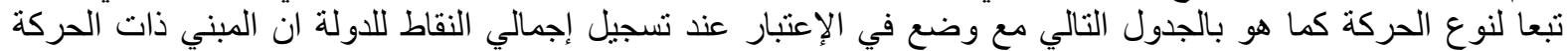

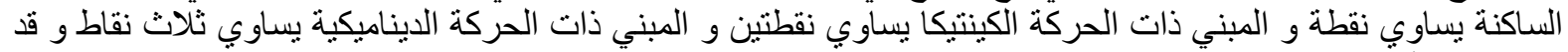

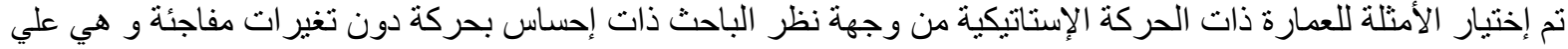
سبيل الثثال فقط لا الحصر حيث من الصعارة الصبة حصر كل المباني المتحركة الإستاتيكية

جدول (r) يوضح النقاط المضيئة بالدول طبقا لروية الباحث الموضحة بأعلي الجدول المصدر : الباحث

\begin{tabular}{|c|c|c|c|c|c|c|}
\hline الأدو ارد & وقت التفيذ & تأثير الحركة علي & الجزمرء & 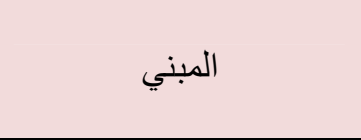 & إلنمالي & 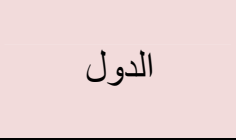 \\
\hline \multicolumn{7}{|c|}{ العمارة المتحركة الديناميكية } \\
\hline 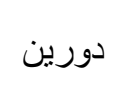 & $19 r \leq$ & مؤثرة بالكتلة و الو اجهة & الدور الأول & تورنينت مستشفي سو لاريوم & $r$ & ليون - فرنسا \\
\hline ثاد ألار & $r \cdot 1 r$ & مؤثرة بالكتلة & 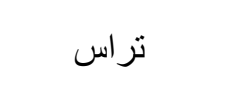 & بيت شريفى ها & r & طهر ان - إيران \\
\hline 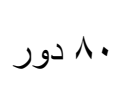 & جاريٍ & مؤثرة بالكتلة و الو اجهة & كتلة المبني & برج & r & دبي - الإمار ات \\
\hline 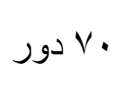 & التنفيذٍ & مؤثرة بالكتلة و الو اجهة & كتلة المبني & Rotating Skyscraper & $r$ & موسكو - روسيا \\
\hline \multicolumn{7}{|c|}{ العمارة المتحركة الكينتيكا } \\
\hline ا 10 دور & $r \ldots l$ & غير مؤثرة & الجزء الدائري & 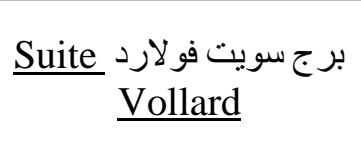 & $r$ & كوريتيبا بار انا - \\
\hline دور واحد & $r \ldots$ & غير مؤثرة & 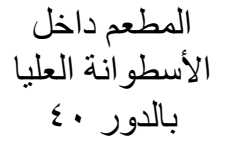 & فندق جر اند حياة & 7 & 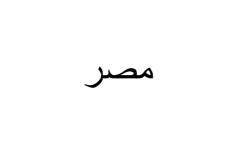 \\
\hline 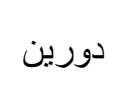 & 1971 & غير مؤثرة & بالدور كا الو العلوي & برج القاهرة & & \\
\hline
\end{tabular}




\begin{tabular}{|c|c|c|c|c|c|c|}
\hline ع أدوار & 1911 & غير مؤثرة & البرج & قصر البارون & & \\
\hline دور و احد & $19 \vee 9$ & غير مؤثرة & الكرة العلوية علية إرتئ & البرج الكبير من أبر اج & r & الكويت - الكويت \\
\hline 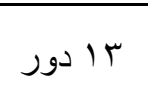 & $r \cdot 1 \cdot$ & مؤثرة بالو اجهة & 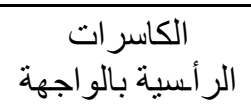 & $\begin{array}{l}\text { ThyssenKrupp } \\
\text { Quarter Essen }\end{array}$ & r & ويسبورگ و إلمن - \\
\hline ا & $191 \mathrm{~V}$ & مؤثرة غير ملحوظة & المشربية بالو اجهة & معهذ العالم العربي & r & باريس - فرنسا \\
\hline دورين & & مؤثرة بالو اجهة & بانو هات أمام & $\begin{array}{c}\text { معرض تقنيات كيفر } \\
\text { SHOWROOM } \\
\text { KIEFER TECHNIC }\end{array}$ & r & 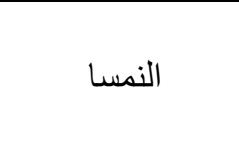 \\
\hline دور واحد & $r \cdot I r$ & غير مؤثرة & الأخير (دور الالدور) & المطعم الدوار لوسيل & r & جدة السعودية \\
\hline دور واحد & 1971 & غير مؤثرة & المطعم بالدور & المطعم لاروند الدوّار & r & مدينة هونولولو \\
\hline دور واحد & & غير مؤثرة & الأخمج بالدور & المطعم أعلي فندق السفير & r & مدينة مومباي \\
\hline دور واحد & & غير مؤثرة & الأخم بالدور & المطعم أعلي برج بريما & r & سنغافورة \\
\hline دور واحد & $19 \vee r$ & غير مؤثرة & المطعم بالدور & مطعم • بس أعلي برج & r & تورندو - كندا \\
\hline دور واحد & $197 \varepsilon$ & غير مؤثرة & الأخبم بالدور & مطعم برج بريتيش تيليكوم & r & لندن - إنجلتر ا \\
\hline 19 19 دور & & مؤثرة بالكتلة & واجهات المبني & $\begin{array}{c}\text { ناطحة سحاب } \\
\text { A cactus sprouts }\end{array}$ & r & قطر \\
\hline جr دور & $r \cdot I r$ & مؤثرة & و واجهات المبني & أبر اج البحر & r & أبو ظبي - الإمارات \\
\hline 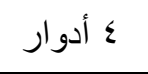 & & 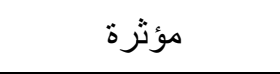 & و واجهات المبني & المسرح الجديد & 1 & شنغهاي - الصين \\
\hline \multicolumn{7}{|c|}{ العمارة المتحركة الإستاتيكية } \\
\hline م או دور & $r .10$ & مؤثرة بالكتلة & 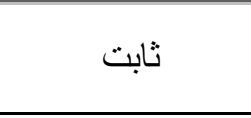 & بر جنغهاى الملتوي & \multirow{4}{*}{$\varepsilon$} & شنغهاى - الصين \\
\hline • 11 دور & جاريٍ & مؤثرة بالكتلة & 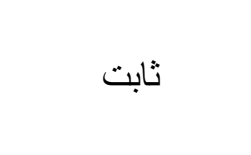 & $\begin{array}{c}\text { Tianjin CTF } \\
\text { Finance Centre }\end{array}$ & & ت تانجان - الصين \\
\hline (17 دور & $r \cdot 1 r$ & مؤثرة بالكتلة & ثابت & سو هو جالاكسي & & بكين - الصين \\
\hline ا 10 دور & $r \cdot 1 r$ & مؤثرة بالكتلة & ثابت & مركز الإبتكار & & هونك كونك \\
\hline ع إ دور & $r \ldots o$ & مؤثرة بالكتلة & ثابت & الجذع المتحول & 1 & مالمو - السويد \\
\hline
\end{tabular}




\begin{tabular}{|c|c|c|c|c|c|c|}
\hline 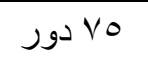 & & مؤثرة بالكتلة & ثابت & برج إنفينيتي أو كيان & \multirow{5}{*}{0} & \multirow{3}{*}{ دبي - الإمار ات } \\
\hline سד آ دور & $r \cdot 1 \cdot$ & غير مؤثرة & ثابت & برج الخليفة ـ دبي & & \\
\hline r או دور & $r \cdot 1 \cdot$ & غير مؤثرة & ثابت & $\begin{array}{l}\text { Ocean Heights } \\
\text { (Dubai) }\end{array}$ & & \\
\hline \multirow[t]{2}{*}{ مب دور } & $r+11$ & مؤثرة بالكتلة & ثابت & $\begin{array}{c}\text { THE CAPITAL } \\
\text { GATE }\end{array}$ & & \multirow{2}{*}{ - أبو ظبي - الإمارات } \\
\hline & & مؤثرة بالكنلة & ثابت & DNA & & \\
\hline · • • دور & $r \cdot 11$ & غير مؤثرة & ثابت & $\begin{array}{c}\text { Taiwan's Agora } \\
\text { Garden }\end{array}$ & 1 & تايبه - تايوان \\
\hline 1 ^ دور & $r \ldots q$ & مؤثرة بالو اجهة & ثابت & AQUA TOWER & \multirow{4}{*}{$\varepsilon$} & \multirow{2}{*}{ شيكاغو } \\
\hline 7111 دور & $r \ldots q$ & مؤثرة بالكتلة & ثابت & CHICAGO SPIRE & & \\
\hline V أدوار V V & 1909 & مؤثرة بالكتلة & ثابت & متحف جوجنهايم & & نيويورك \\
\hline r זד دور & $r+1 V$ & مؤثرة بالو اجهة & ثابت & بر سكني & & - مبامي - فلوريدات المتحدة \\
\hline 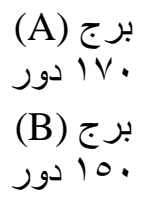 & $r \cdot 1 r$ & مؤثرة بالكتلة & ثابت & 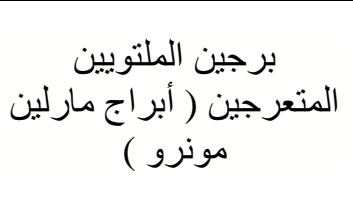 & \multirow[t]{2}{*}{ r } & ميسيسوجا - كندا \\
\hline זד دور & $r .17$ & مؤثرة بالكتلة & ثابت & $\begin{array}{l}\text { Trump International } \\
\text { Hotel and Tower } \\
\text { (Vancouver) }\end{array}$ & & البريطانية - كندا \\
\hline \multirow[t]{3}{*}{ سو دور } & $r .19$ & مؤثرة بالكتلة & ثابت & ( برج جدة الملتوي & \multirow{2}{*}{ r } & جدة \\
\hline & $r . I V$ & مؤثرة بالو اجهة & ثابت & محطة مترو الرياض & & الرياض - السعودية \\
\hline & $r .10$ & مؤثرة بالكتلة & ثابت & برج كريستال & 1 & أسطنبول -تركيا \\
\hline ا & $r \ldots r$ & مؤثرة بالكتلة & ثابت & $\begin{array}{l}\text { The Gherkin } \\
\text { Tower London }\end{array}$ & \multirow{3}{*}{ r } & \multirow{3}{*}{ لندن - بريطانيا } \\
\hline 9 أدوار & $r \ldots r$ & مؤثرة بالكتلة & ثابت & City Hall & & \\
\hline 0 & $r+1 V$ & غير مؤثرة & ثابت & Arena Tower & & \\
\hline دور واحد & $r \cdot 11$ & مؤثرة بالكتلة & ثنابت & $\begin{array}{l}\text { Art Science } \\
\text { Museum }\end{array}$ & \multirow[t]{2}{*}{ r } & \multirow[t]{2}{*}{ سنغافورة } \\
\hline ^ & $r \cdot 10$ & مؤثرة بالكتلة & ثابت & المركز التعليمي التفاعلي & & \\
\hline ror & $r+11$ & مؤثرة بالكتلة & ثابت & F\&F Tower & 1 & بنما - بنما \\
\hline 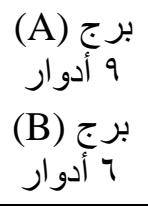 & 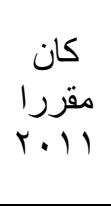 & مؤثرة بالو اجهة & ثابت & $\begin{array}{c}\text { أبر اج الحجر Stone } \\
\text { Towers }\end{array}$ & 1 & القاهرة - مصر \\
\hline
\end{tabular}




\begin{tabular}{|c|c|c|c|c|c|c|}
\hline • • دور & $r \ldots \lambda$ & مؤثرة بالكتلة & ثابت & Avaz Twist Tower & 1 & سر ايفو - هوسك \\
\hline ع ع دور & $r . I V$ & مؤثرة بالكتلة & ثابت & Generali Tower & 1 & ميلان - إيطاليا \\
\hline 10 10 دور & $r .17$ & مؤثرة بالو اجهة & ثابت & DC Tower & 1 & فيينا ـ النمسا \\
\hline N دور & $r .19$ & غير مؤثرة & ثابت & Lakhta Center & 1 & سانت بيترسبيج \\
\hline דr دور & $r \ldots \lambda$ & مؤثرة بالكتلة & ثابت & $\begin{array}{l}\text { Mode Gakuen } \\
\text { Spiral Towers }\end{array}$ & 1 & ناجويا ـ اليابان \\
\hline 11 1 دور & 1999 & مؤثرة بالكتلة & ثابت & البرج التو أم بتروناس & 1 & كو الالمبور \\
\hline
\end{tabular}

من الجدول السابق يتضح أن هناك تسابق بين المدن و الدول لتصميم و تنفيذ عمارة متحركة و الغالب منها ما بين الكينتيكا

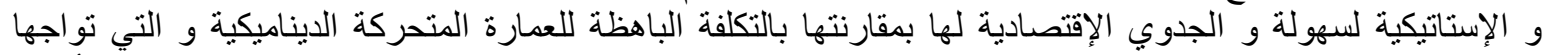

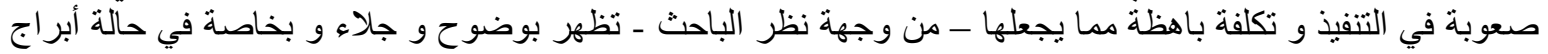

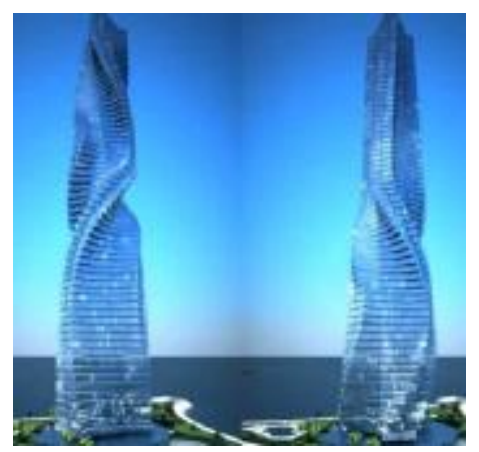

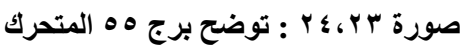
ديناميكي : توصن برمي

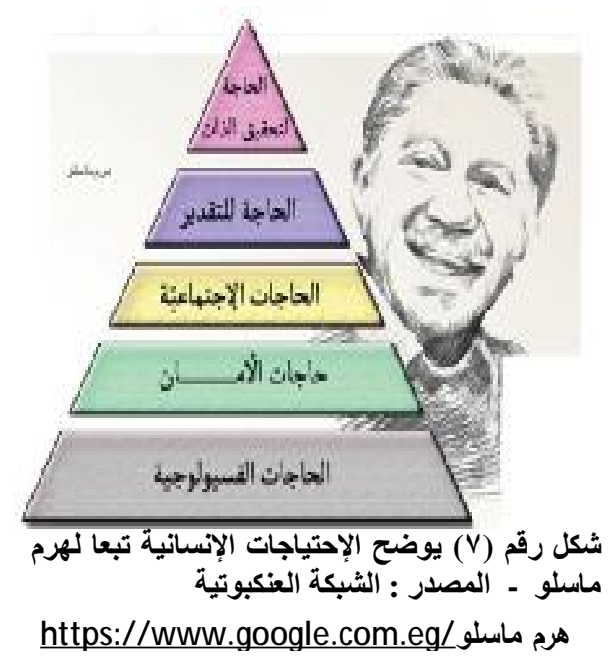

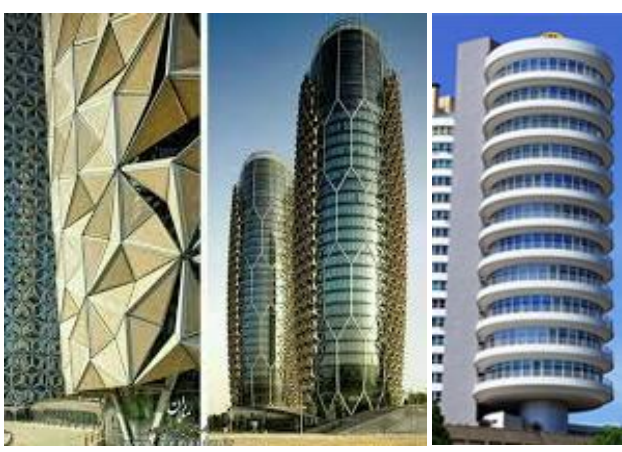

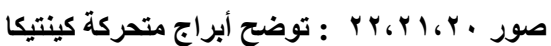

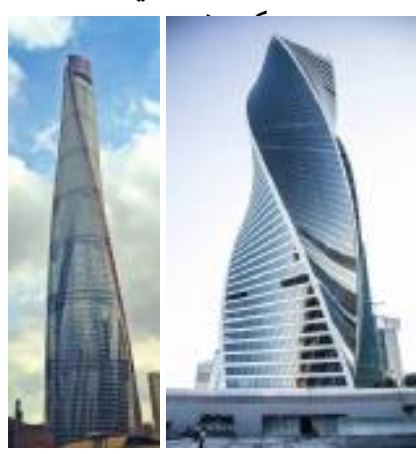

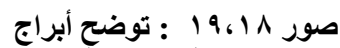
متحركة إستاتيكية

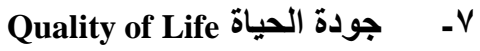

• " ظهرت جودة الحياة أثناء المناقثنات التاريخية لفلاسفة اليونان

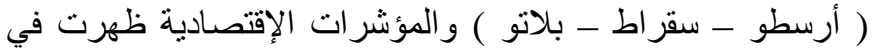

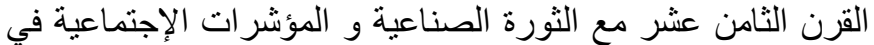

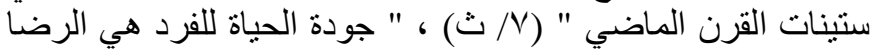

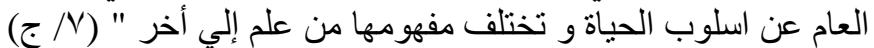

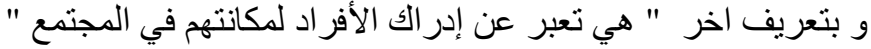

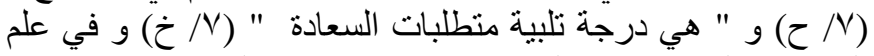

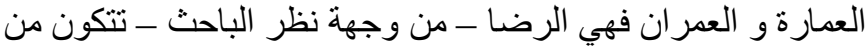

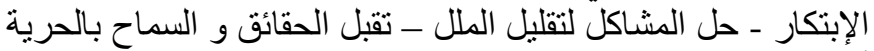

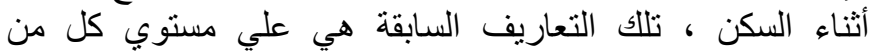

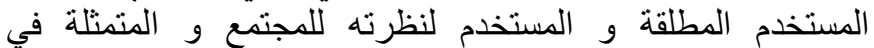

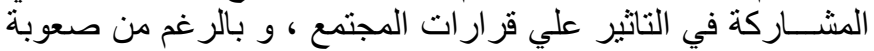

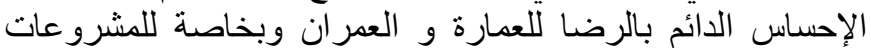

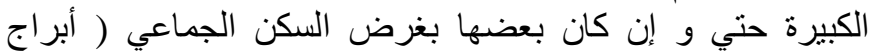
سكنية ) " أن أفضل طريقة لقياس نوعية الحياة هي قياس مدى تلبية البية

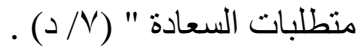




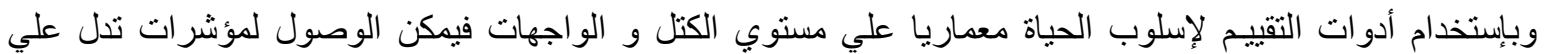

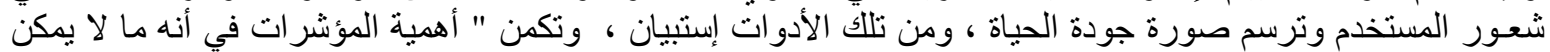

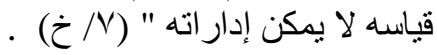

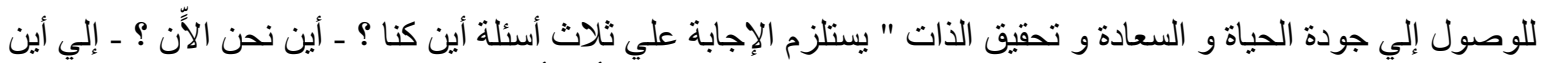

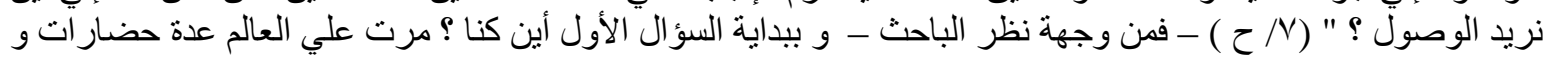

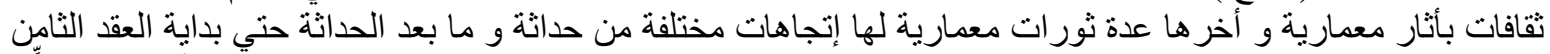

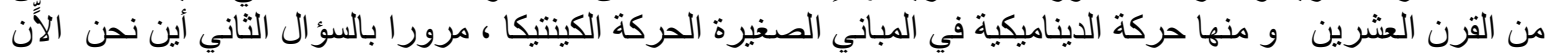

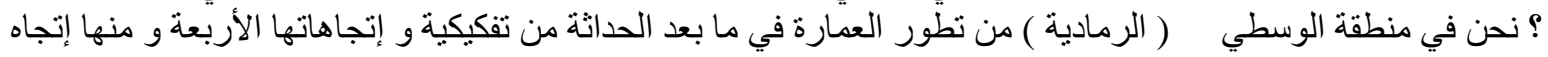

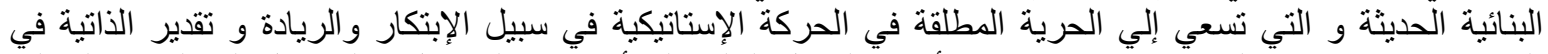

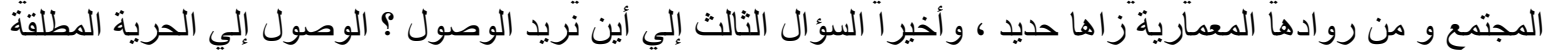

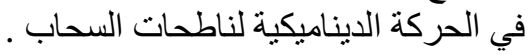

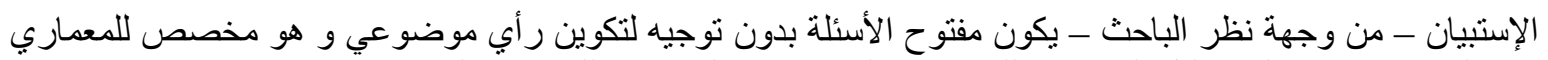

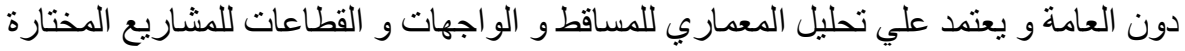

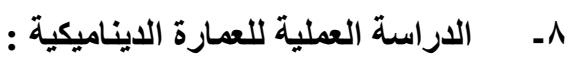

1ـ التجارب العالمية للعمارة الايناميكية :

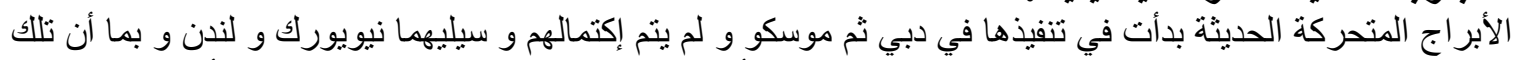

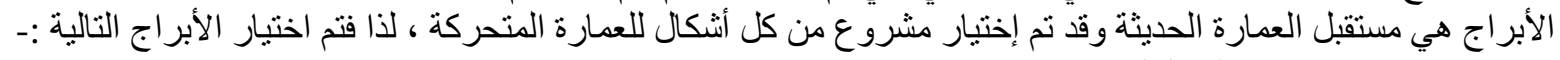

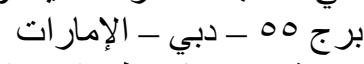

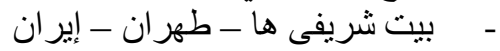

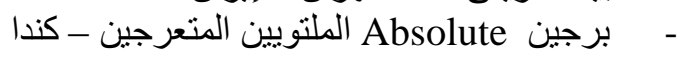

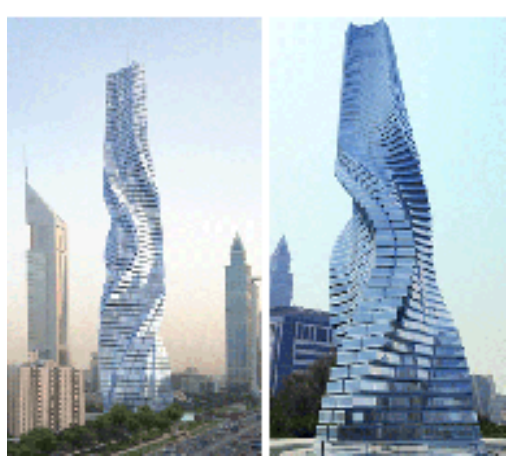

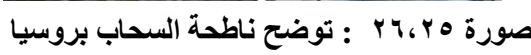
بواجهتها المتغيرة مع الزمن

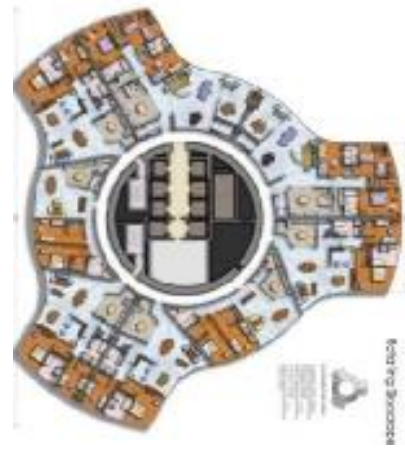

شكل 1 : يوضح المسقط الأفقي للجزء السكني

$$
\begin{aligned}
& \text { - - معرض تقنيات كيفر }
\end{aligned}
$$

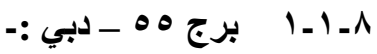

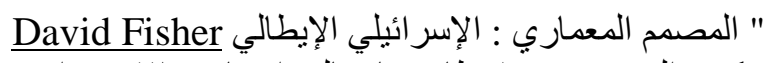

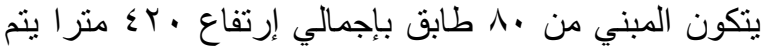

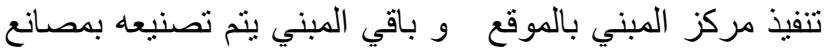

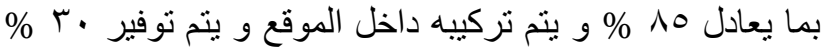

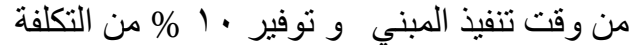

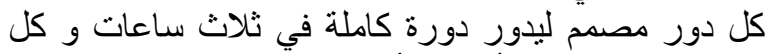
دور يدور بإنفصال عن الأدوار الأخري دوري

سينت توليد الطاقة من توربينات الرياح الراح و و ألواح الخلايا

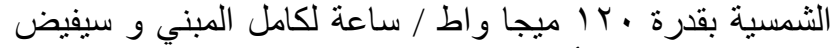

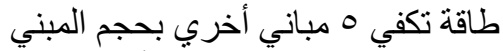

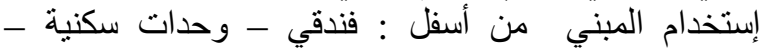

$$
\begin{aligned}
& \text { وحدات إدارية و ترفيهية - فيلات دوبليكس المبن }
\end{aligned}
$$

شكل الحركة : دور انية حول محور رأسي (مركز المبني)

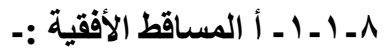

المساقط الأفقية بشكل عام دائري و يضاف إليها ثلاث

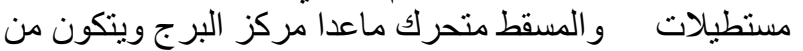

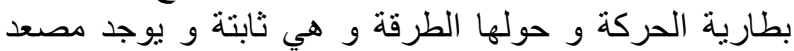
خاص لسيار ات مالكي الفيلات الدوبلكس 


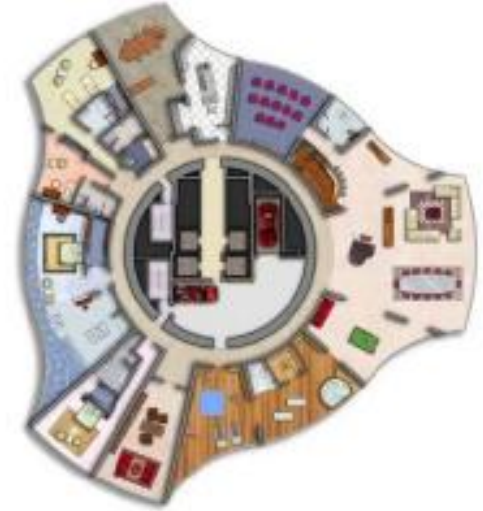

شكل 9 : يوضح المسقط الاققي للجزء السكني

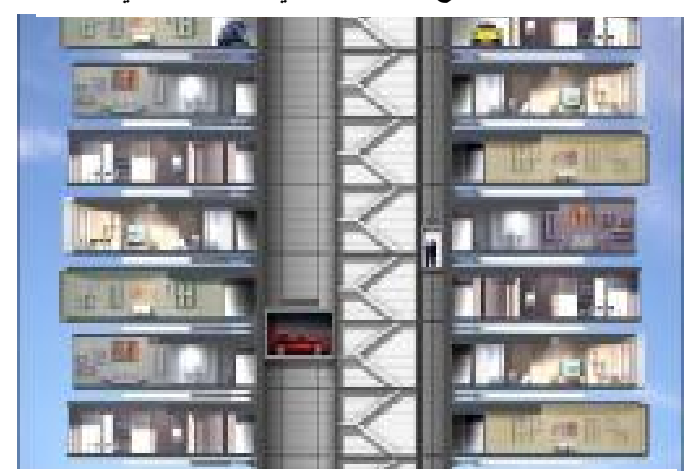

صورة VV : توضح قطاع المبني ( جزء أفقي من القطاع

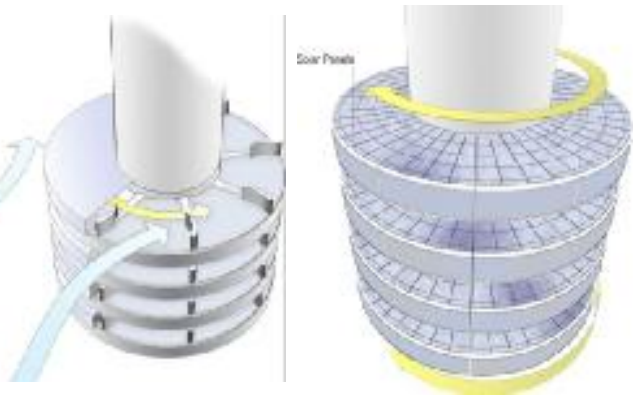

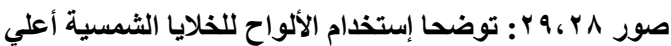

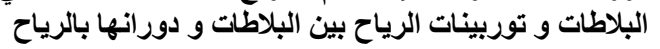

• إيجابيات التصميم للمساقط الأفقية :

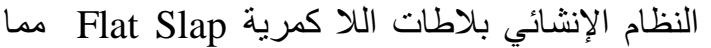
يعطي الحرية في عمل المباني حسب الإنب الرغبة دون التقيد بالكمر بالإضافة إلي تخفيف الوزي الوزن الحو ائط علي مديول إلثعاعي الثي

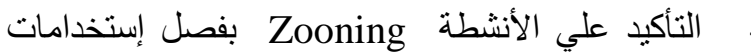
المبني رأسيا و بفصل بطليدي الاريات الحركة لكل إستخدام

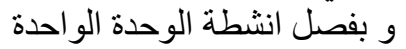

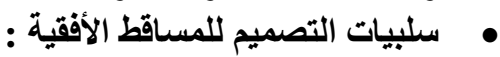

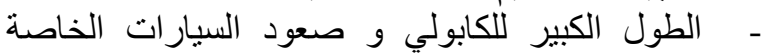
و موقع الوحدات الإدارية و الترفيهية هي أحمال ز زائدة

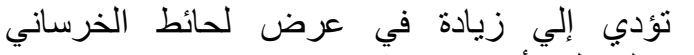

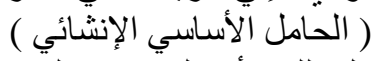

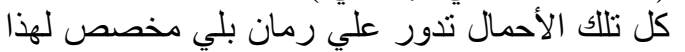
الغرض مما يحتاج إلي صيانة دورية لإنية

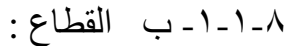
• إيجابيات التصميم للقطاع : التطاع :

- - دوران المسقط الأفقي بؤدي إلي تغيير المطل الذي الذي تطل عليه كل وحدة تعمل علي :-

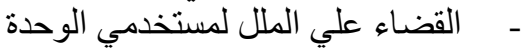

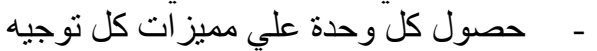

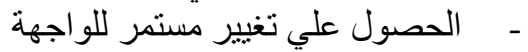

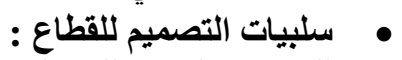

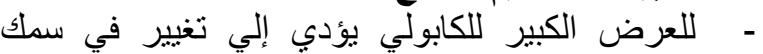
البلاطة ليكون شبيه بالمثلث بإرتفاع كبير البردي عند تلافي فيري

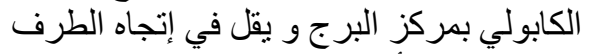

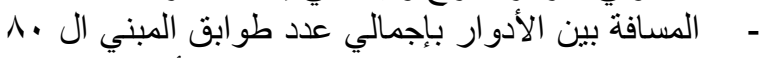

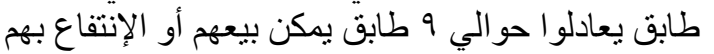

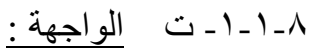
إيجابيات التصميم للواجهة : التهاجة

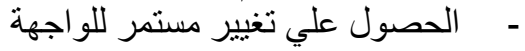

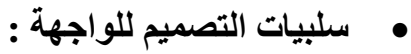

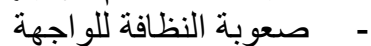

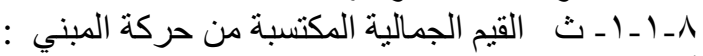
أبرز سمة للمبنى سوف تكون دور ان معظم الطو ابق حول قلب مركزي ولذا فإن الطو ابق لن تكون متطابقة مما سيسمح

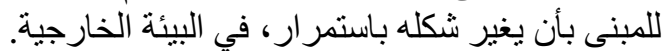

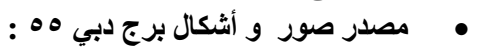

\section{برجب+دبي+المتحرك\&//www.google.com.eg/search?q}
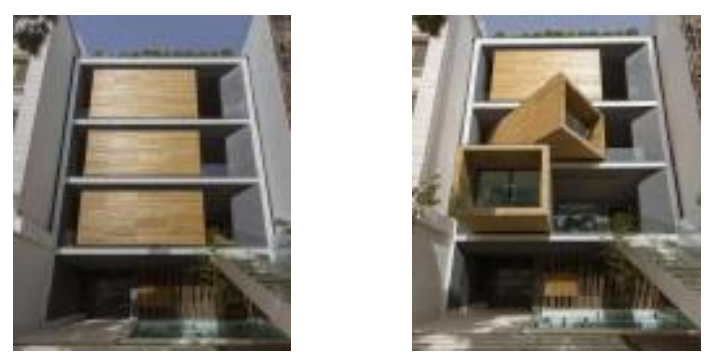

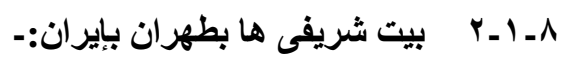

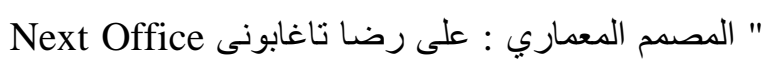

بالتعاون مع مساعدين فى النو احى الإنشائية و الميكانيكية

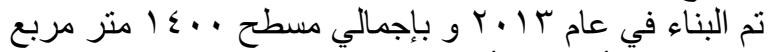

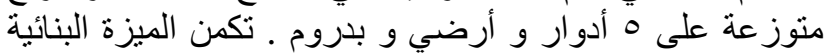

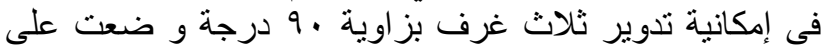




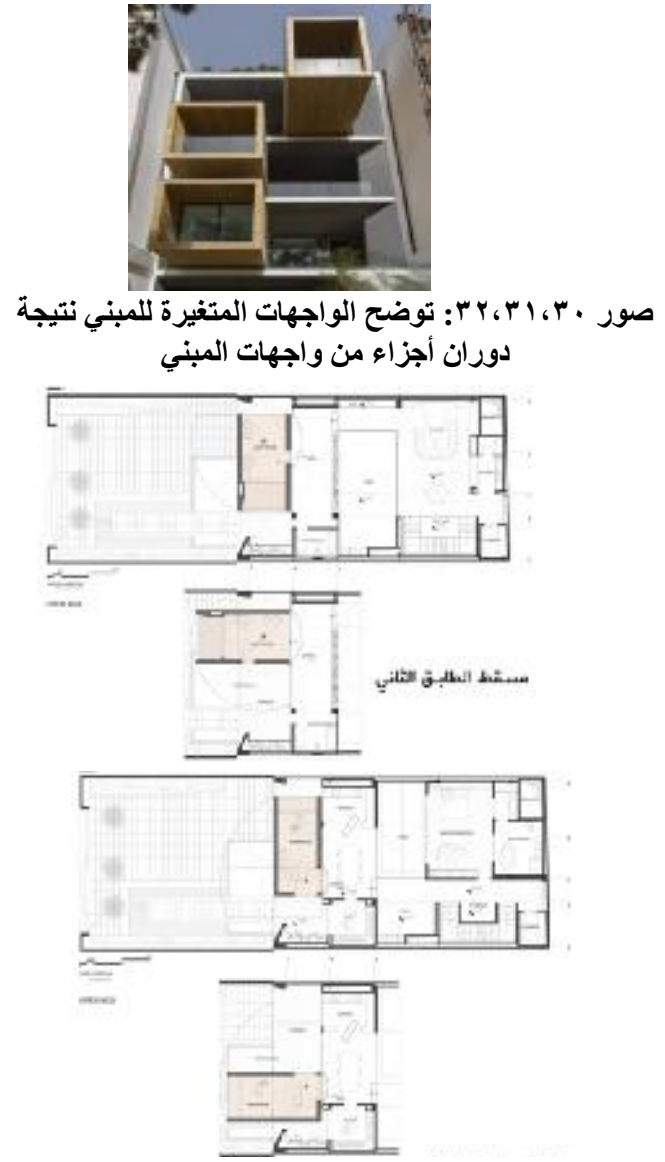

شكل • 1، 11 : يوضحا المساقط الأققية من الدور الثاني حتي الثالث قبل و بعد دوران جزء من كتلة واجهة الأورة المبني

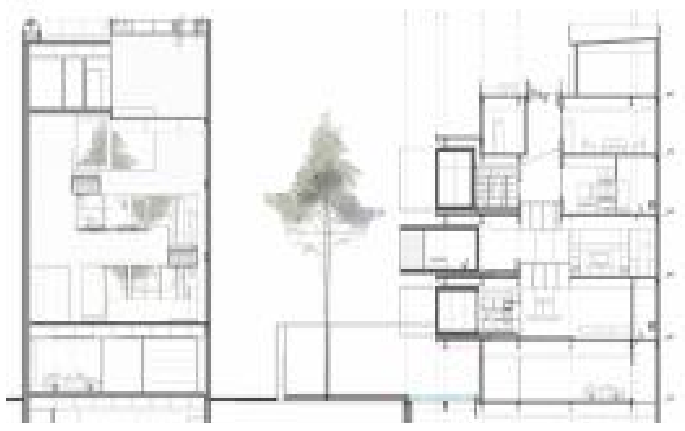

شكل r 1، آ ا : يوضحا القطاعات موضحات دوران الجزء
التوالي فى الأدوار الثلاثة و قد أستمدت هذه الفكرة من آلية التعامل مع المنصات المسرحية و يتكون هذا الادو النظام من ثناثة

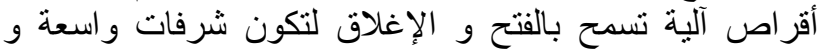

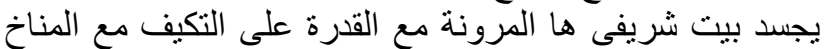

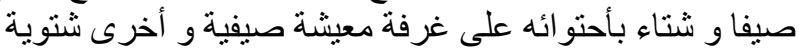

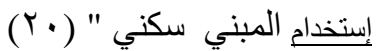

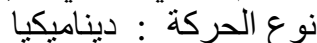

شكل الحركة : حركة دور انية حور مديكة محور ر أسي بالو اجهة

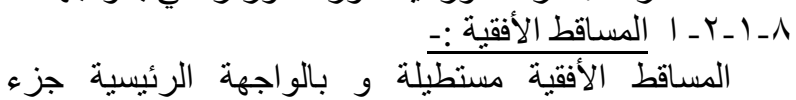

مستطيل يتم دور انه ليتحول إلي تر اس الف •

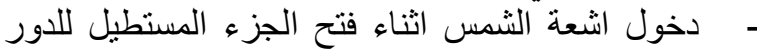
الأول للمغطس بالدور البدروم التماء

- - التكلفة المنخفضة نسبيا لأشكال أخري من لألغور العمارة الديناميكية

يمكن للمبني ان يكون له جار فالتغيير في الواجهة الرئيسية فقطن للمبني

• إستبيات التصميم للمساقط الأفقية :

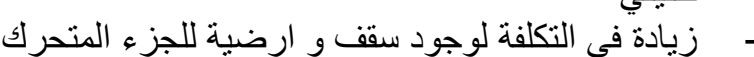

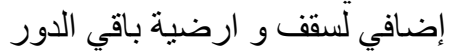

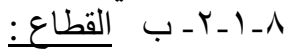

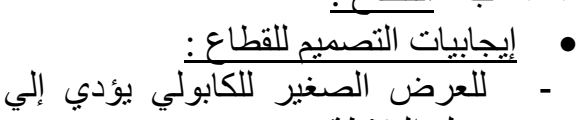
سمك البلاطة صغير • هدر فيبات التصميم للقطاع :

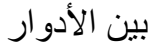

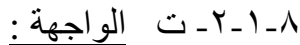
• -

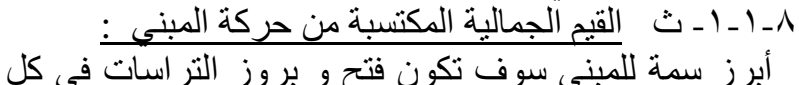

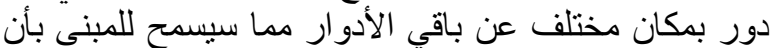
يغير شكله باستمرار، في البيئة الخارجية.

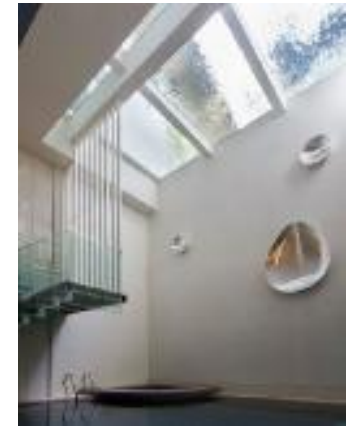

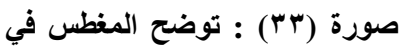

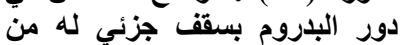

الزجاج لاخول الشعة الثمس عند لهن

فتح التراس

https://www.archdaily.com/522344/sharifi-ha-house-nextoffice

• مصدر صور و أشكال بيت شريفى ها : 
Aـ ا_ـ برجين Absolute World الملتويين المتعرجين ( أبراج مارلين مونرو ) - مدينة ميسيسوجا - كندا :

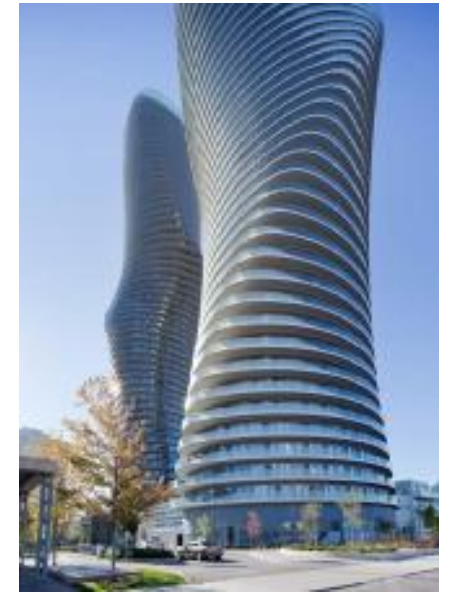

صورة (ع ب) : توضحا واجهة المبني الملتوي

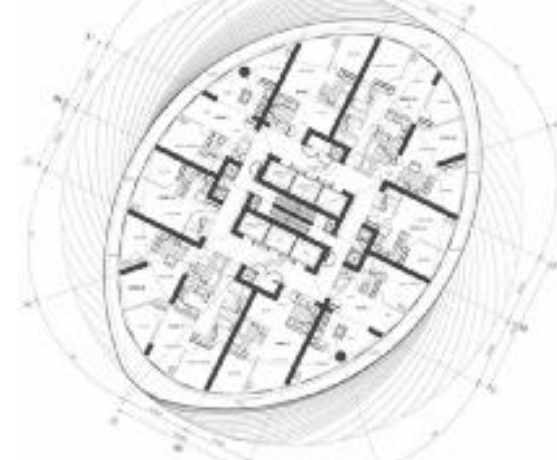

شكل (r ( ) : يوضح المسقط الأفقي للأدوار الإدارية

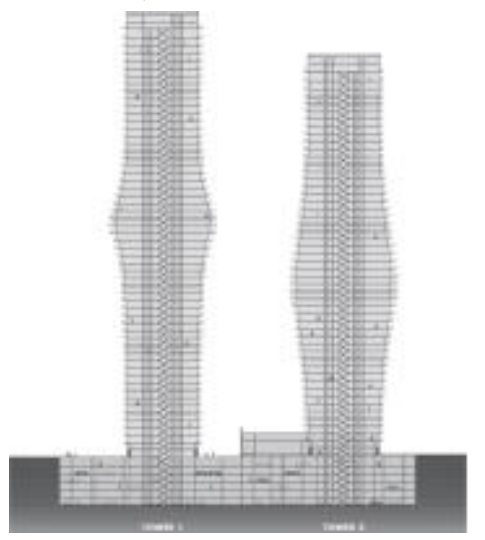

شكل (ب ا ) : يوضح قطاع رأسي للبرجين

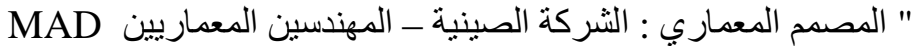

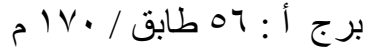

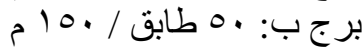

إستخدام المبني سكني

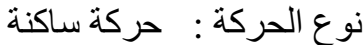

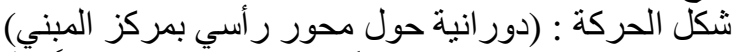

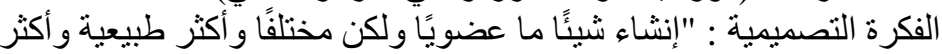

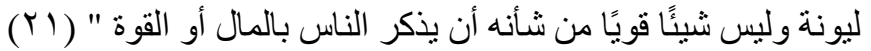

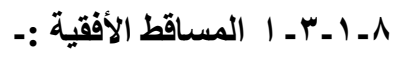

المساقط الأفقية الرئيسية بيضاوية

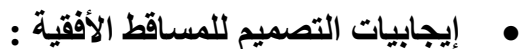

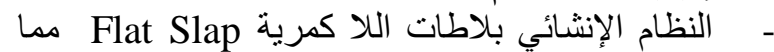

يعطي الحرية في عمل المباني حسب الإنب الرغبة دون التبة التقبد

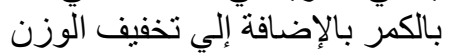

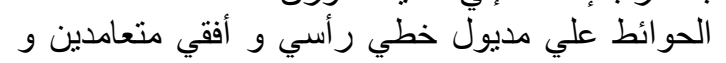

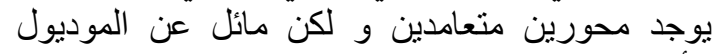

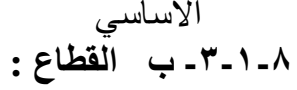

إيجابيات التصميم للابطاع :

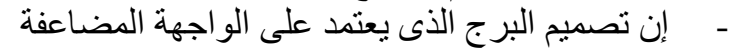

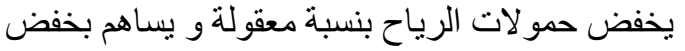

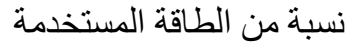

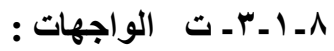

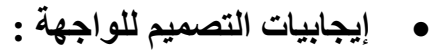

- - الحصول علي إستمر ارية الحركة في الكتلة الساكنة :

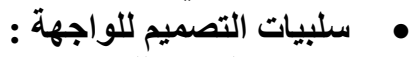

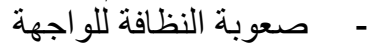

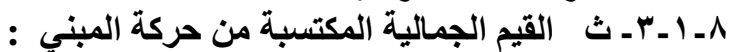

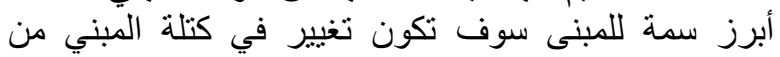

الخارج كحركة إستاتيكية بدون تكلفة الديناميكية فئية

https://en.wikipedia.org/w/index.php?title=Absolute World\&oldid=885263026 

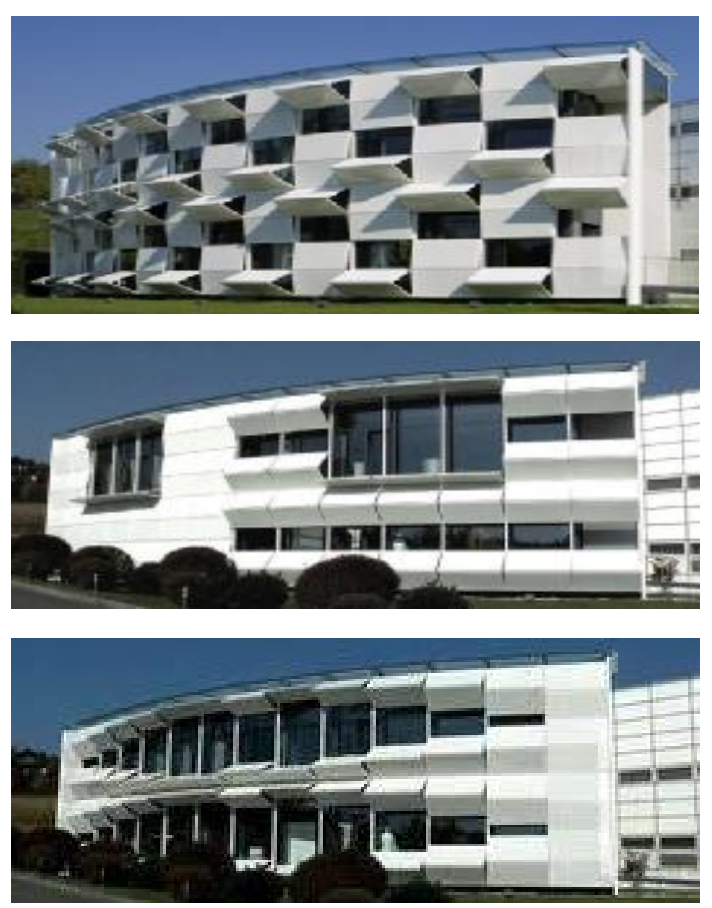

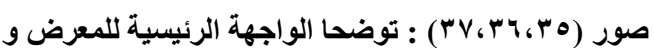

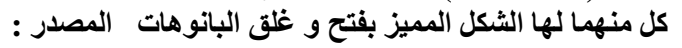
http://noticias.arq.com.mx/Detalles/21720.ht ml\#.XE9USFwzayL

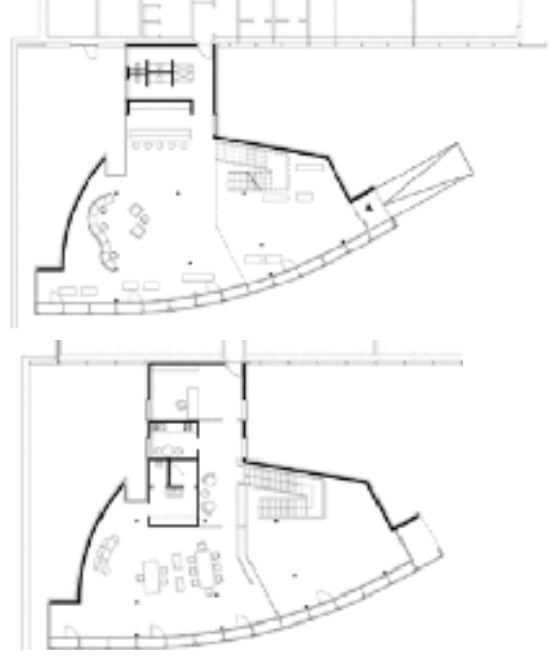

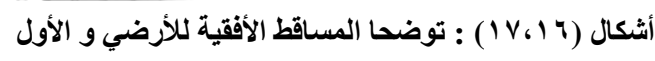

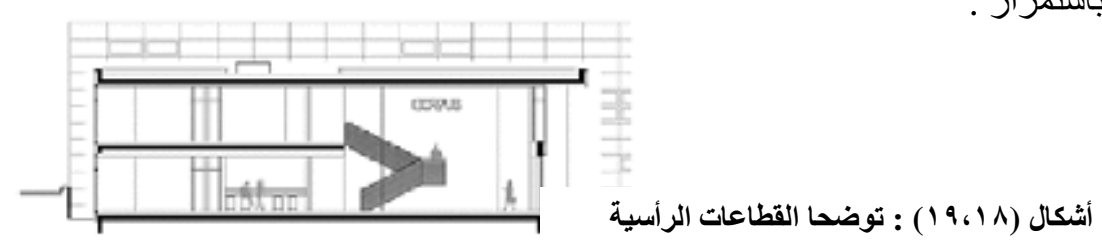

• مصدر صور و أشكال معرض تقنيات كيفر :

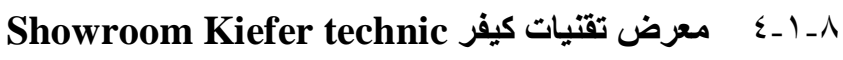

المصمم المعماري : DI Ernst Giselbrecht

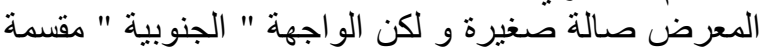

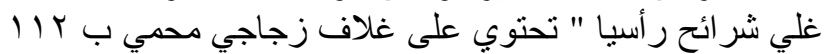

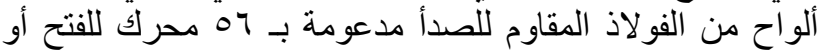

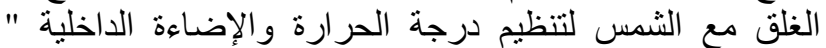

$$
\text { شكل الحركة : في خط خستيكا مستقيم رأسيا }
$$

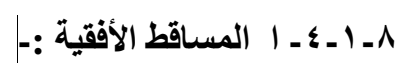

المساقط الأفقية شبه مثلث بالضلع الثالث منحني مضاف إلي المثلث مربع هو خدمات

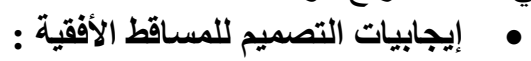

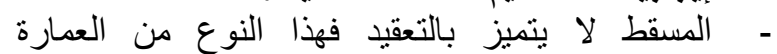

المتحركة لا تتطلب مطلب محدد بالمسقط الأفقي

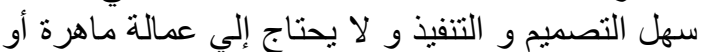
تكنولو جيا متقدمة

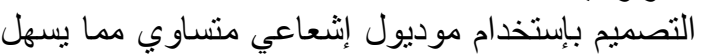

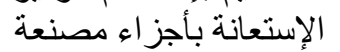

- ائط صالة العرض تتميز بالو اجهة الرئيسية

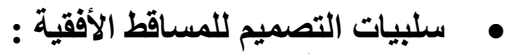

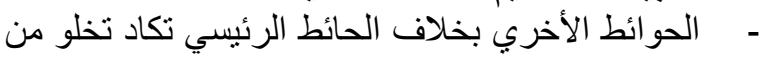

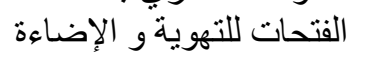

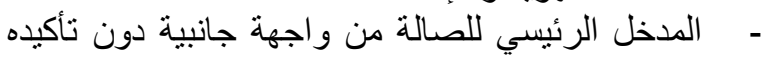

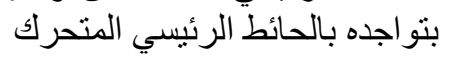

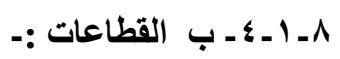

$$
\text { إيجابيات التصميم القطاعات : }
$$

الحركة منطبقة رأسيا فعند الفتح تعمل علي انهاب كاسرة الفهرة

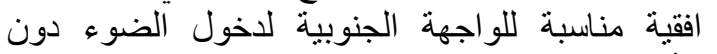

$$
\text { 1ـ الأشعة المباشرة }
$$

$$
\text { • إيجابيات التصميم القطاعات : }
$$

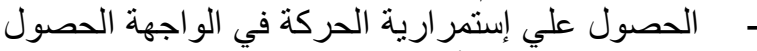

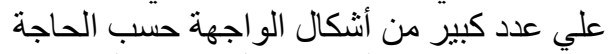

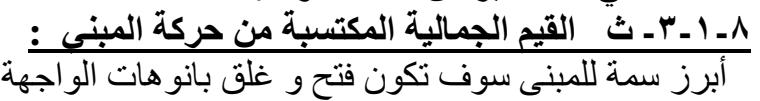

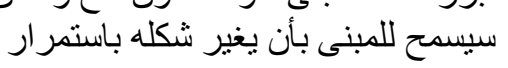

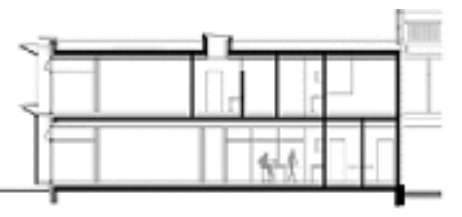

http://noticias.arq.com.mx/Detalles/21720.html\#.XE9USFwzayL 
9 -

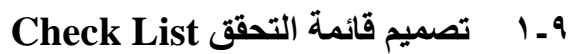

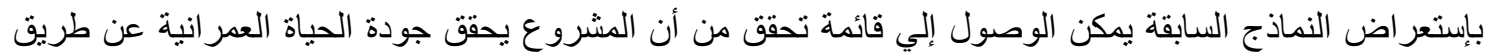

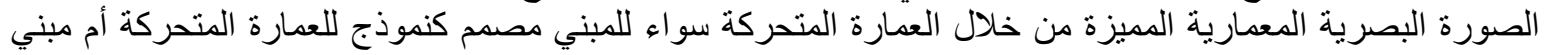

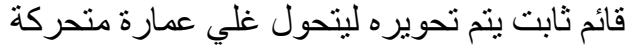

جدول ؛ : يوضح قائمة التحقى للمنهجية المقترحة و درجات للمبني الصالح لكل من العمارة الايناميكية المصدر : الباحث

\begin{tabular}{|c|c|c|c|c|c|c|c|c|}
\hline & \multicolumn{3}{|c|}{ مبني ثابت تم تعديله للحركة } & \multicolumn{3}{|c|}{ مبني جديد يتم تصميمه } & & \\
\hline & إستاتيكية & كينتيكا & ديناميكية & إستاتيكية & كينتيكا & ديناميكية & & \\
\hline الدرجات & ضعيف & متوسط & جيد & ضعيف & متوسط & جيد & & \\
\hline القصوي & من(·) & من(·\%) & من(·^\%) & من(·) & | من(·\%) & من(·) & & \\
\hline 0 & & & & & & & المرونة في تغيير & علي \\
\hline 0 & & & & & & & الخدمات إلي الفر اغات الوصن & المستوب \\
\hline 0 & & & & & & & تكامل الإتصـال بين & الأفقية \\
\hline 0 & & & & & & & توزيع و موقع الإنشاء & \\
\hline 0 & & & & & & & تأكيد المداخل & على \\
\hline 1 . & & & & & & & عدم الإحتياج لمحددات & مستوي \\
\hline 0 & & & & & & & سهولة الوصول إلي & الأفقية \\
\hline$\underline{\varepsilon}$ & & & & & & & الإجمالي علي مستوب الأفقية & \\
\hline 0 & & & & & & & تأكيد المداخل & علي \\
\hline 1. & & & & & & & تأكيد معالجات البيئة الغيدة & الو اجهات \\
\hline 1. & & & & & & & إستهلاك طاقة غير & \\
\hline 1. & & & & & & & المحلية في الدفردات & \\
\hline 0 & & & & & & & التشطيب المناسب & \\
\hline 0 & & & & & & & تغيير في الإحتياج إلي تيلة & \\
\hline 0 & & & & & & & ترابط الو أجهات ر أسيا & \\
\hline 1. & & & & & & & الديناميكيا في التشكيل & \\
\hline 0 & & & & & & & وظائفها من الو اجهة و توات & \\
\hline
\end{tabular}




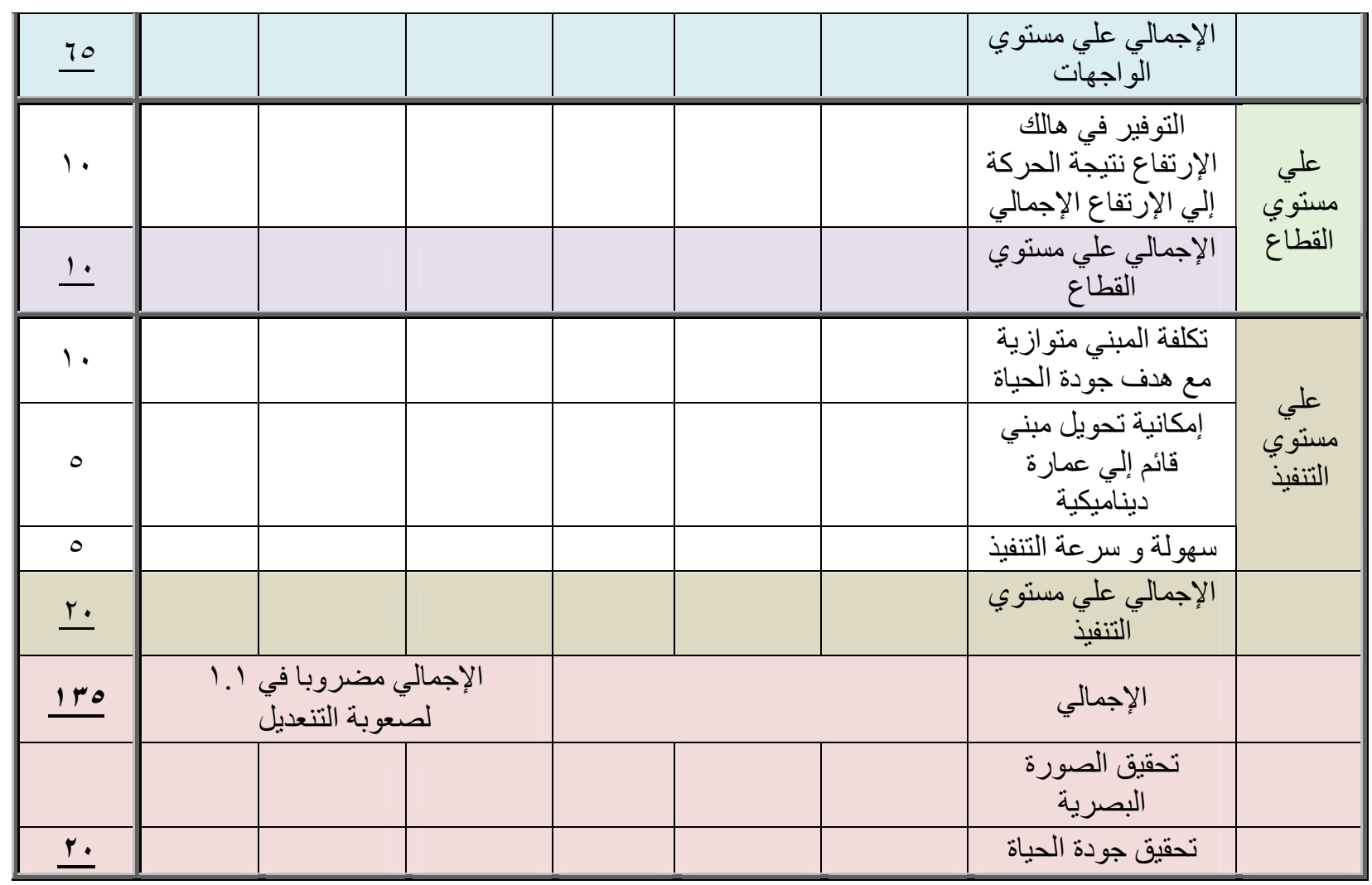

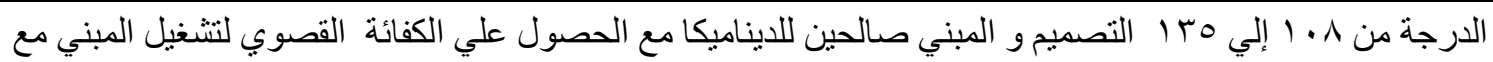

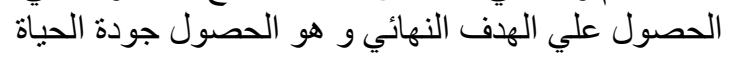

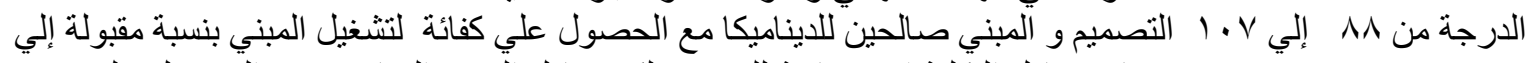

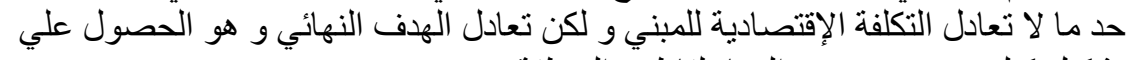

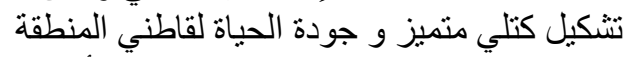

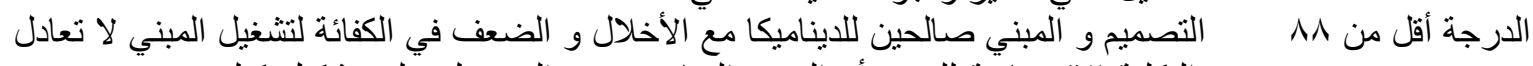

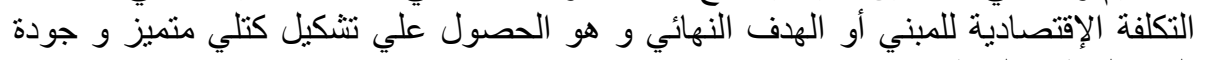

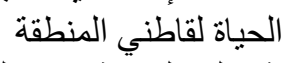

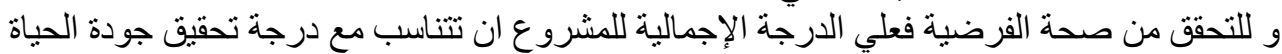

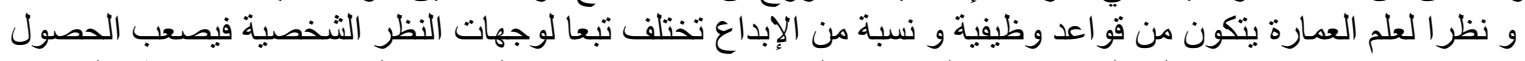

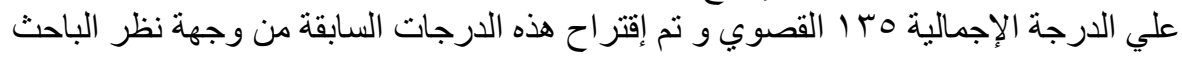

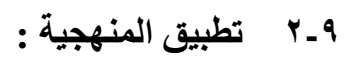

بتطبيق المنهجية علي الدر اسة التطبيقية كما في الجدول التالي 
جدول (•) يوضح تطبيق المنهجية المقترحة علي مشاريع الدراسة الميدانة المختارة و درجات كل مشروع المصدر : الباحث

\begin{tabular}{|c|c|c|c|c|c|}
\hline المشروع & المشروع & المشروع الثاني & المشروع الأول & & \\
\hline تقنيات كعرض & 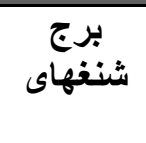 & شريثى & برج 000 & & \\
\hline 0 & 0 & 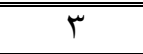 & 0 & المرونة في تغيير الفراغات & \multirow{8}{*}{ المستي } \\
\hline 0 & 0 & $r$ & 0 & إمكانية الوصول من الخدمات إلي & \\
\hline 0 & 0 & 0 & 0 & تكامل الإتصال بين الداخل و الخارج & \\
\hline 0 & 0 & 0 & 0 & توزيع و موقع الإنشاء و علاقته بالفر اغ & \\
\hline 1 & 0 & 0 & 0 & تأكيد المداخل & \\
\hline 1 . & 1 & $\Lambda$ & - & عدم الإحتياج لمحددات & \\
\hline 0 & 0 & 0 & 0 & سـهولة الوصول إلي سلالم الهروب & \\
\hline ry & $\varepsilon$. & re & $r$. & الإجمالي علي مستوي المساقط الأفقية & \\
\hline 1 & 0 & 0 & 1 & تأكيد المداخل & \multirow{6}{*}{ علي } \\
\hline 1. & 7 & 1. & $\varepsilon$ & تأكيد معالجات البيئة الغير تقليدية علي & \\
\hline$\varepsilon$ & . & $\cdot$ & $\Lambda$ & توفير طاقة غير متجددة & \\
\hline 9 & $\wedge$ & $\mathrm{V}$ & $\Lambda$ & المعاصرة في المفردات & \\
\hline 0 & 0 & 0 & $r$ & التشطيب المناسب & \\
\hline 0 & 0 & 0 & 0 & وظيفة المبنيني إلي تغيير في حالة تغير & \\
\hline 0 & 0 & 0 & $\varepsilon$ & تر ابط الو اجهات ر أسيا و أفقيا & \\
\hline 9 & $1 \cdot$ & 1. & 9 & الديناميكيا في التشكيل (بدون حركة) & \\
\hline$\varepsilon$ & $r$ & 0 & $\cdot$ & تميز الفر اغات و وظائفها من الواجهة & \\
\hline or & $\varepsilon V$ & Or & $\sum Y$ & الإجمالي علي مستوي الو اجهات & \\
\hline $1 \cdot$ & 1. & $r$ & - & التوفير في هالك الإرتفاع الإرتيجة الحركة الإجمالي & \multirow[t]{2}{*}{ علي مستوي القطاع } \\
\hline 1 . & 1 . & $r$ & - & الإجمالي علي مستوي القطاع & \\
\hline 9 & 1. & $\Lambda$ & $r$ & تكلفة المبني منو آزية مع هدف جودة & علي مستوي التنفيذ \\
\hline - & - & - & - & إمكانية تحويل مبني قائم إلي عمارة & \\
\hline 0 & $\varepsilon$ & 0 & 0 & سهولة و سر عة التنفيذ & \\
\hline 19 & 19 & 11 & $1 \pi$ & الإجمالي علي مستوي التنفيذ & \\
\hline 114 & 111 & $1 \cdot r$ & $\wedge$. & الإجمالي للمشروع & \\
\hline \multicolumn{6}{|c|}{ 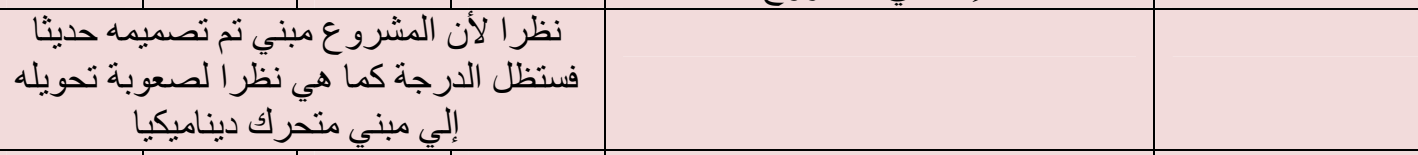 } \\
\hline $1 \varepsilon$ & 17 & 17 & 11 & تحقيق جودة الحياة & \\
\hline & & & & & \\
\hline
\end{tabular}




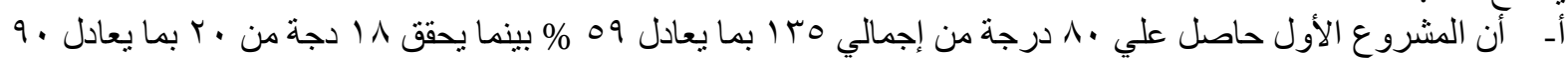

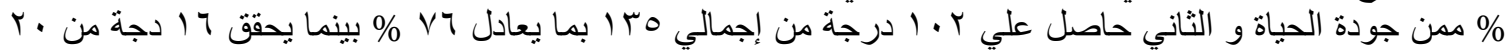

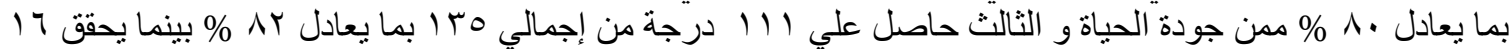

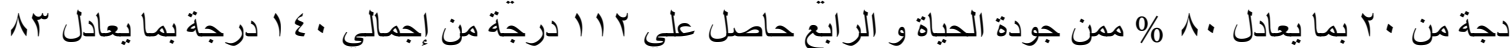

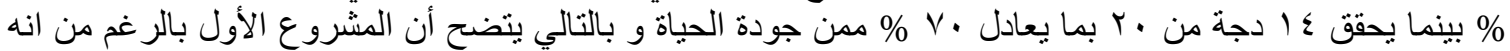

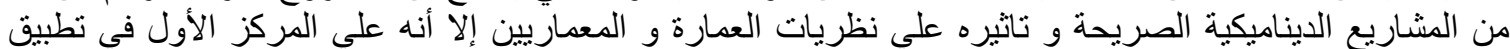

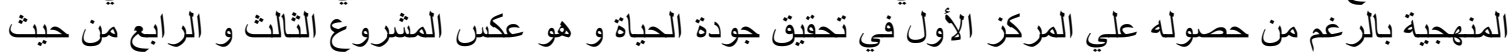

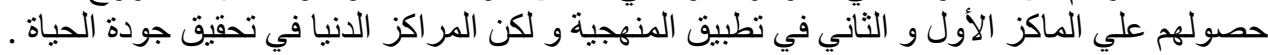
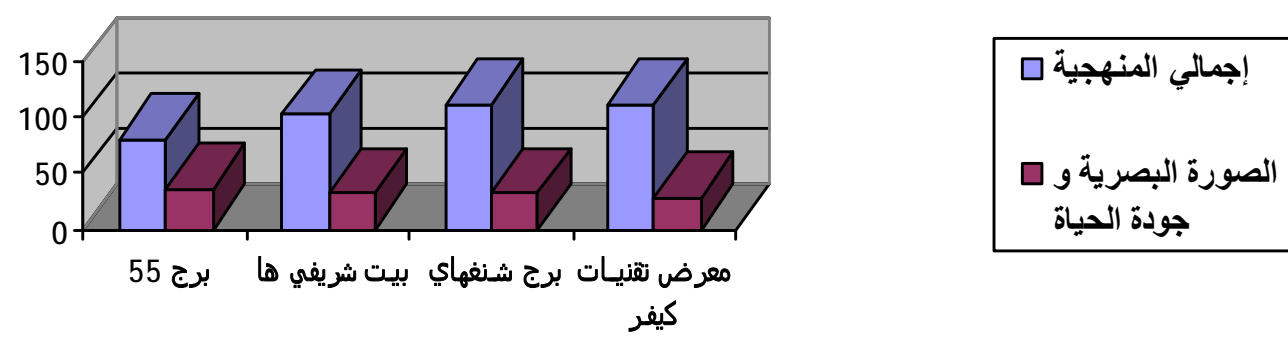

شكل ( • ب) يوضح تحليل تطبيق المنهجية المقترحة علي مشاريع الدراسة الميدانة المختارة و درجات كل مشروع المصدر : الباحث

1.

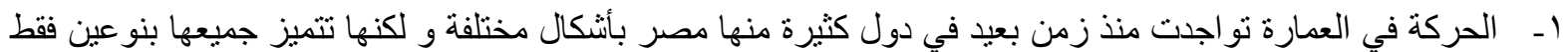
من أنواع الحركة الثناثة ( الحركة الإستاتيكية - الحركة الكينتيكا ـ الحركة الديناميكية ) و قد بد بدأت بالكينتيكا ثم

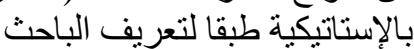
rـ الحركة الإستاتيكية هي نتيجة العمارة التفكيكية بأسلوب إتجاه البنائي الحديث و من رو ادها البارعين بها زها حديد و هو

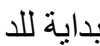

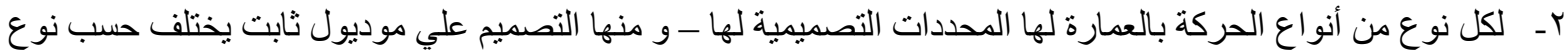

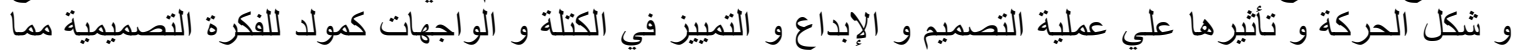

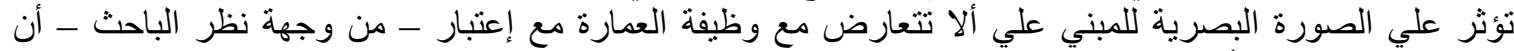

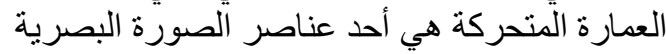

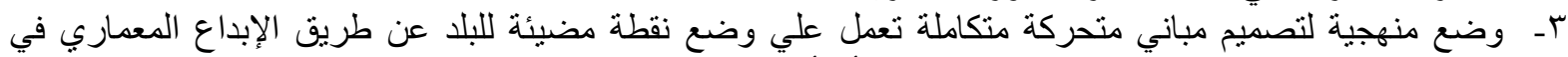

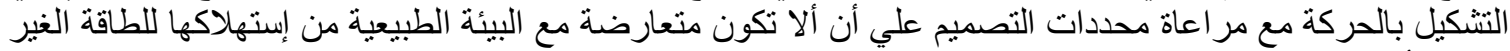

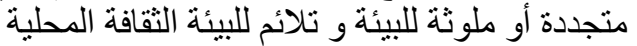

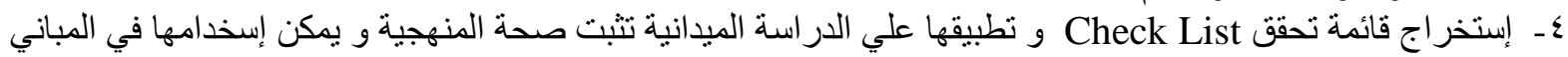
القائمة و في المباني التي سيتم إنشائها

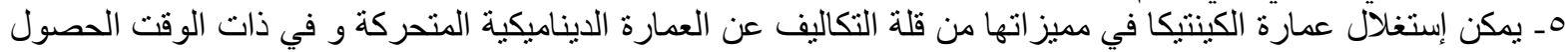

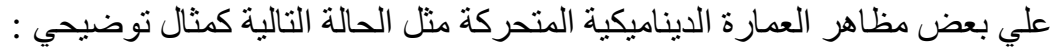

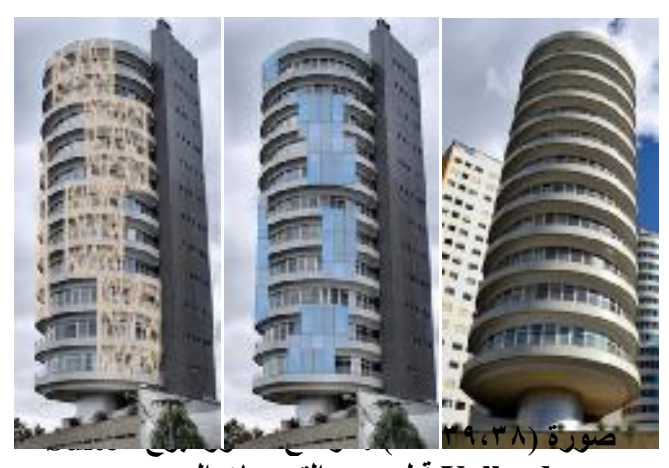

: قبل و بعد التوصيات المصدر : Vollard https://en.wikipedia.org/wiki/Suite Vollar

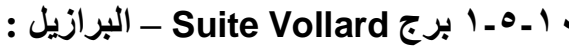

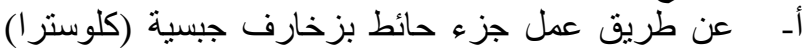

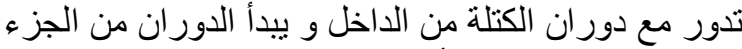

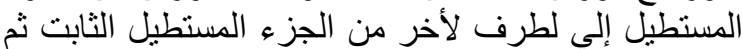

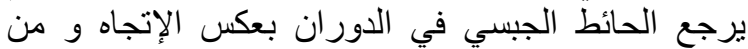

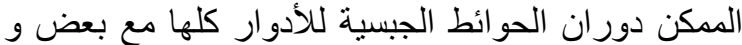

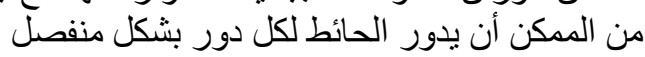

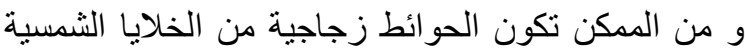
بدلا من الجبسية لإستغلال الجزء الجئ المغلق الجديد كفراغ الجيا داخلي 
ب- عن طريق عمل بروزات كتلية بدلا من التراس و يدور

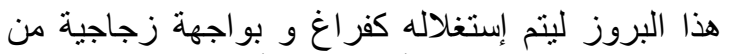

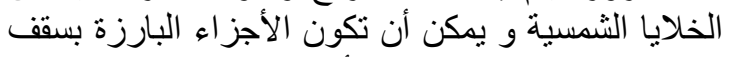

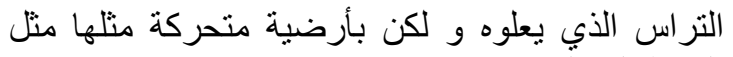
الفراغ الداخلي الإني

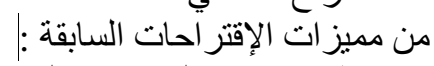

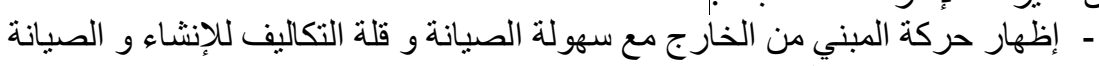

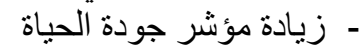

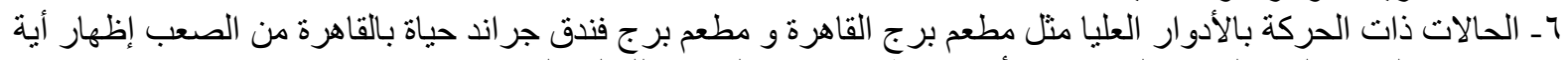

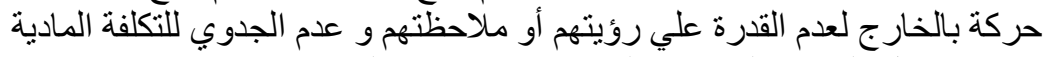

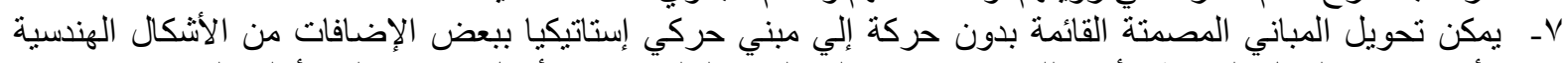

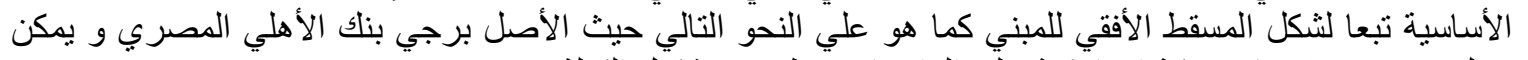
عمل تعديلات لإضفاء حركة إستاتيكية علي الو اجهات فقيط دون تشكيل الكتلة
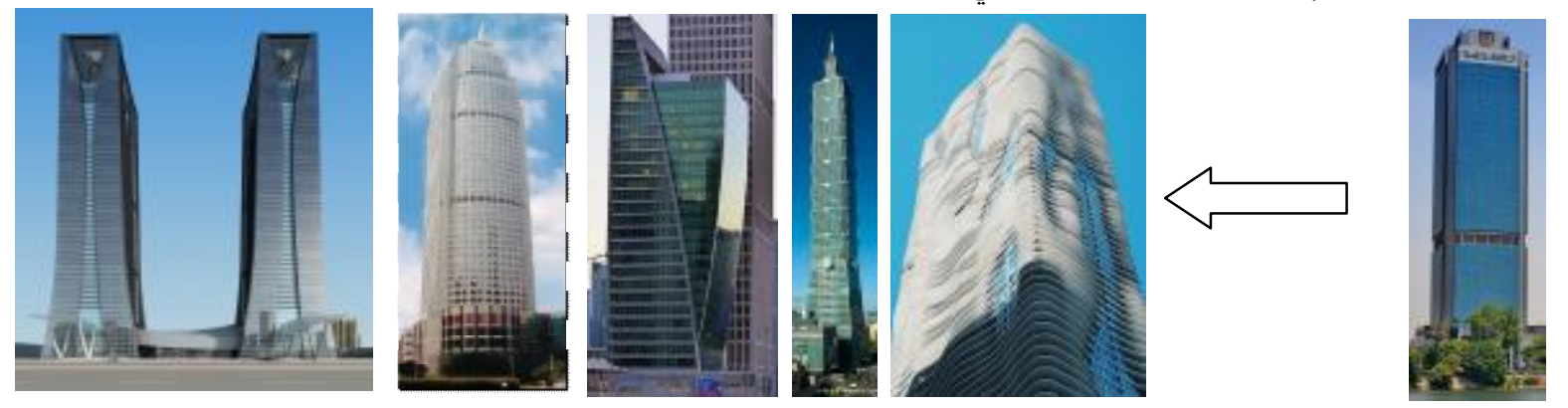

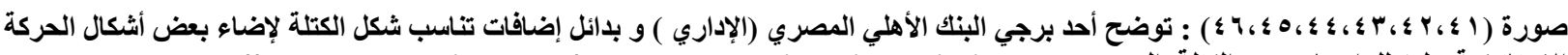

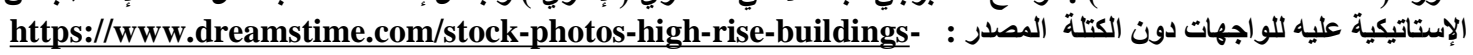

image19211783

يـ - يمكن إنشاء مصانع في مصر لتصنيع أجز اء المباني و بخاصة العالية وو خاصة يتم إنشاء حاليا عدة مدن من الجيل الرابع

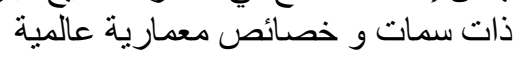

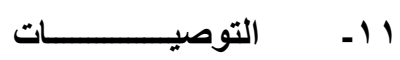

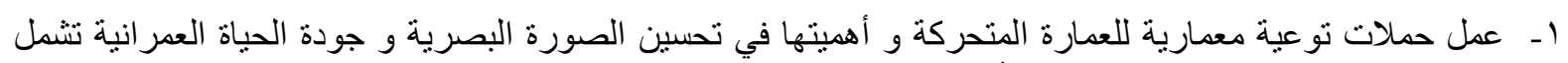

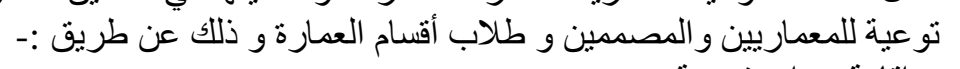

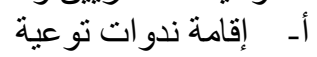

بـ إقامة مسابقة تشجيعية للمباني القائمة سو اء الكينتيكا أو الثابتة و كيفية تحويلها إلي صورة للعمارة الديناميكية المتحركة

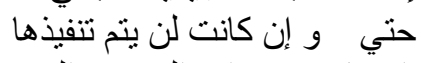

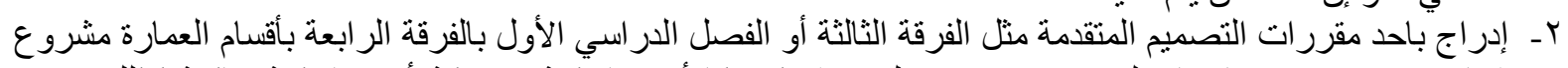

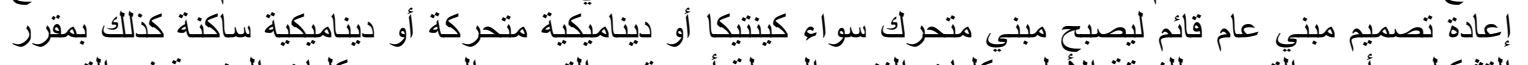

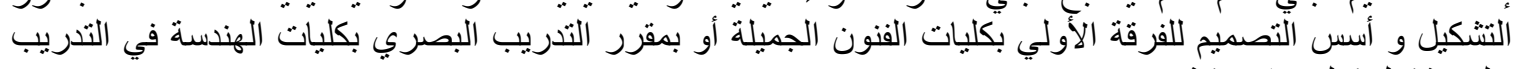

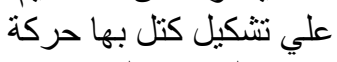

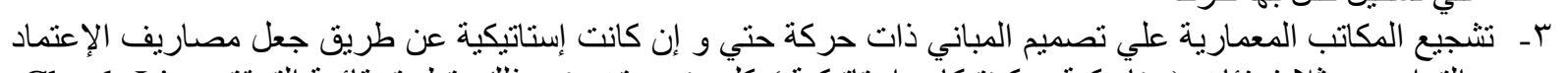

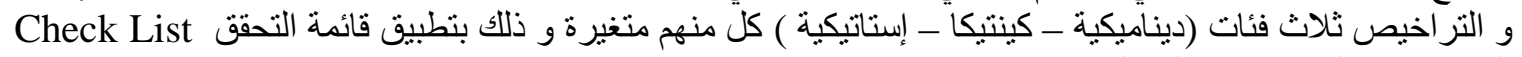

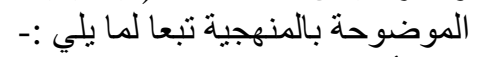

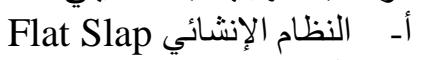

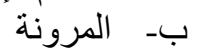
تــ إحتو المرونة المبني لأسس الإستدامة البيئية و المعالجات البيئية للإضـاءة و التهوية و غبر ها 
لكل ما سبق درجة و كلما زادت الدرجة كلما إنخفضت المصاريف داخئ داخل الفئة الو احدة و الفئة الأغلي هي

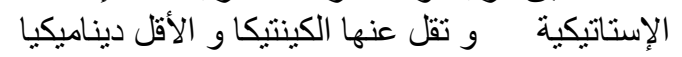

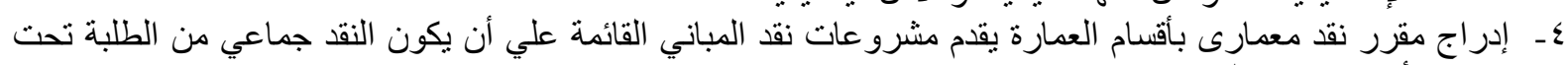
إنشر اف أعضاء هيئة التنريس.

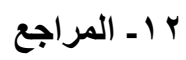

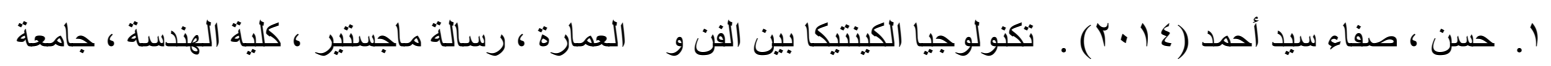
القاهرة ، نقلا عن

Roberts , Adrian, “ Statics and Dynamics with Background Mathematics “, Cambridge University Press , New York, U.S.A., 2003 , p. 55

صفاء سيد أحمد حسن ، مرجع سابق ، نقلا عن

Kohler , Xandra , "Momentum - transformation of movement into architecture", op.c.it , p.45

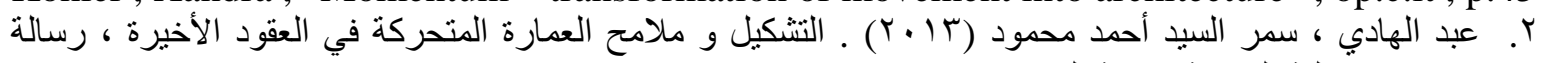

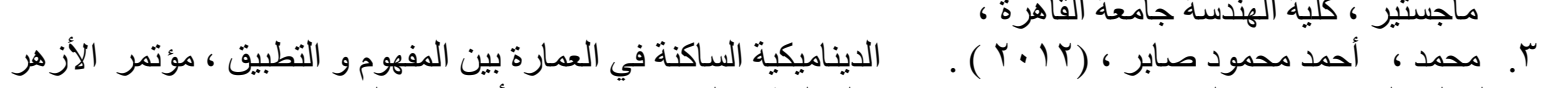

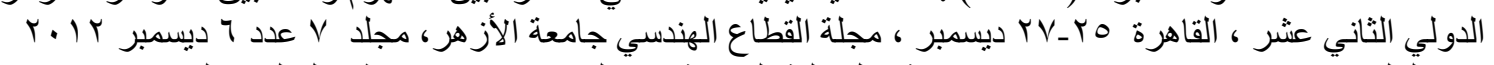

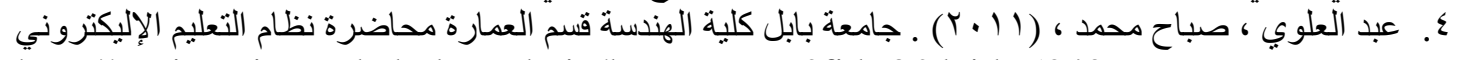
http://engineering.uobabylon.edu.iq/lecture.aspx?fid=3\&lcid=5840

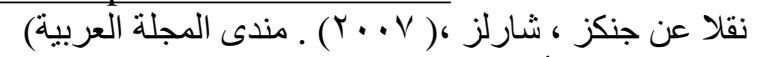

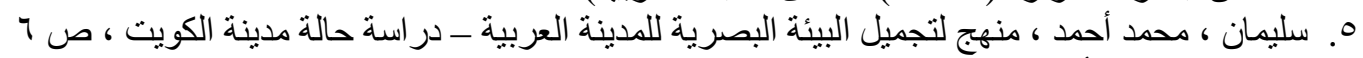

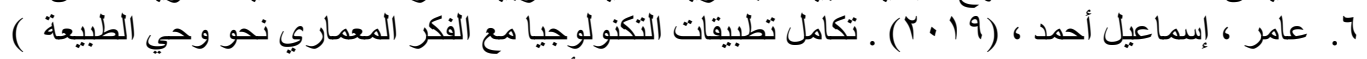

BIOMIMICRY )

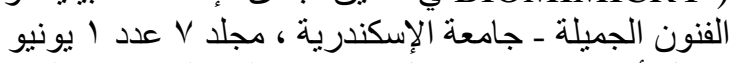

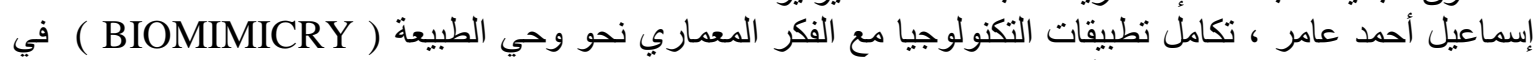

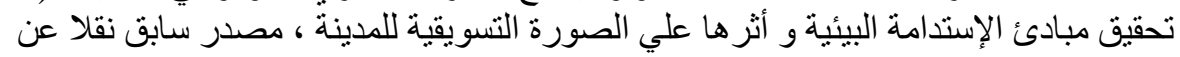

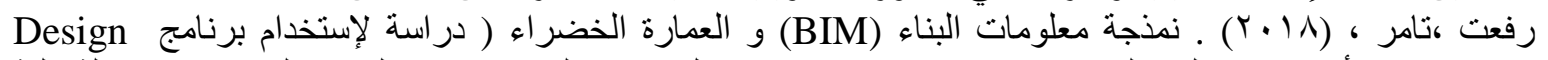
كuilder

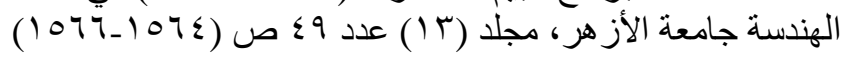

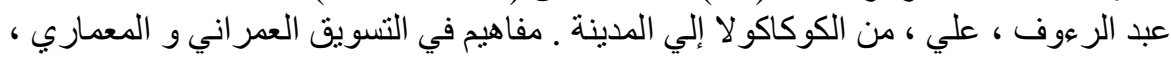
http://cairobserver.com/post/43795184059/concepts-in-city-branding

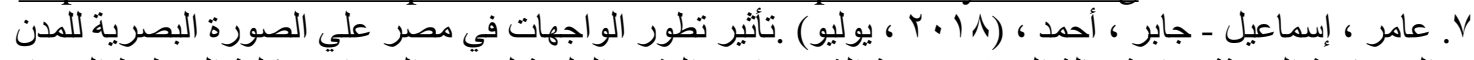

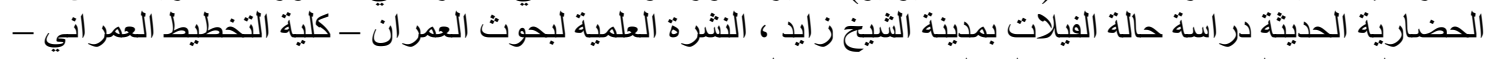

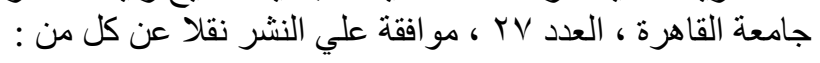

http://medical-dictionary.thefreediction+ary.com/quality+of+life

McCall, S.: 1975, 'Quality of Life', Social Indicators Research 2, pp 229-248 ،

http://www.gdrc.org/uem/qol-define.html

http://www.urbanharmony.org/download/research/files/dr-ayman mostafa.pdf http://medical-dictionary.thefreedictionary.com/quality+of+life https://sites.google.com/site/humansocietyandlife/blog-life/quality-of-life-or-socialwelfare-issues

McCall, S.: 1975, 'Quality of Life', Social Indicators Research 2, pp 229-248 ،

http://www.gdrc.org/uem/qol-define.html

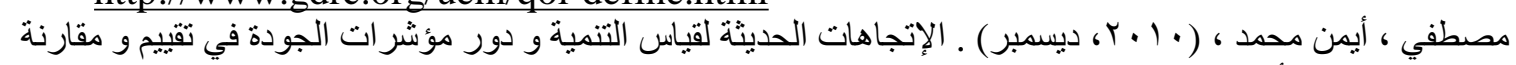

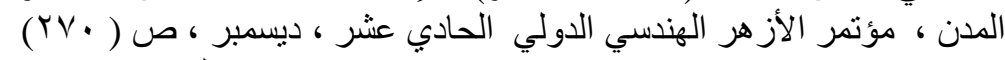

8. https://ar.wikipedia.org/wiki_قصر_البارون_إمبانو

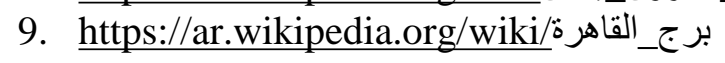

10. http://rahalat.net/hotel/cairohotels/Grand-Hyatt-Hotel-Cairo.php 
11. https://ar.wikipedia.org/wiki/أبر اج_الكويت

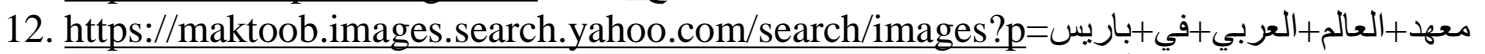

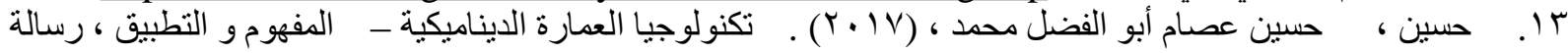

14. https://en.wikipedia.org/wiki/Suite Vollard ماجستير ، كلية الهنسة ، جامعة الزقايق اليقل

15. https://www.facebook.com/dezone2000/posts-مقال-عمارة-التفكيك/deconstruction-

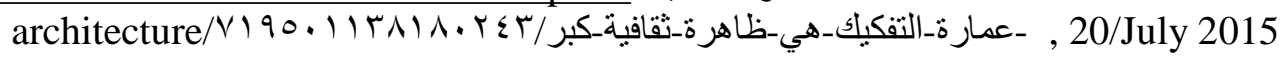

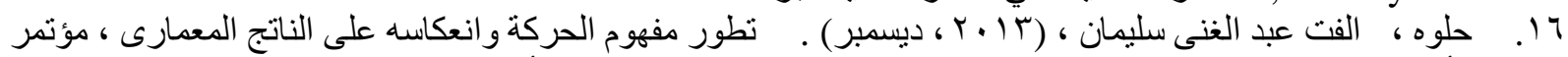

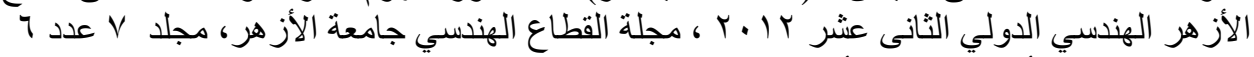

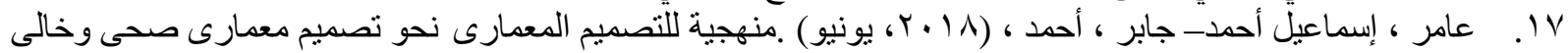

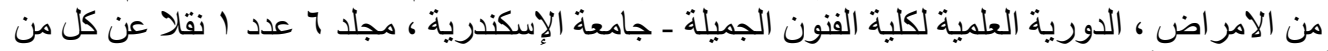

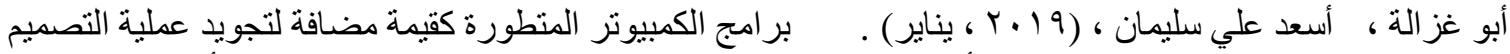

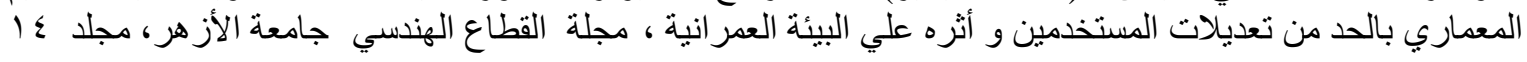
عدد . ع ع

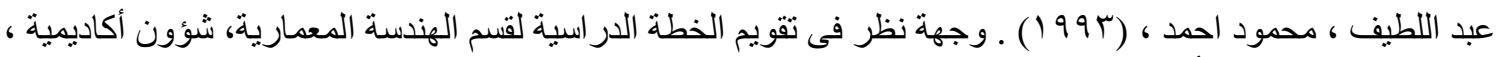

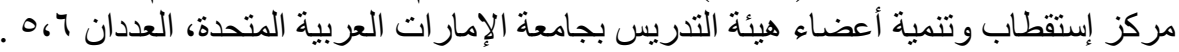

Boker. L., (1964) . Conference on Teaching of Engineering Design, Institute of Engineering Designers,.

Gregory. S., (1966) . The Design Method Harden : Butterworth,.

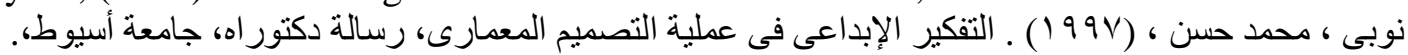

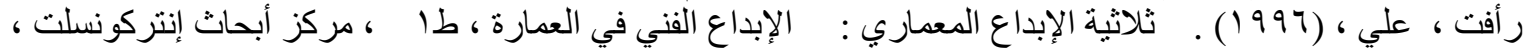

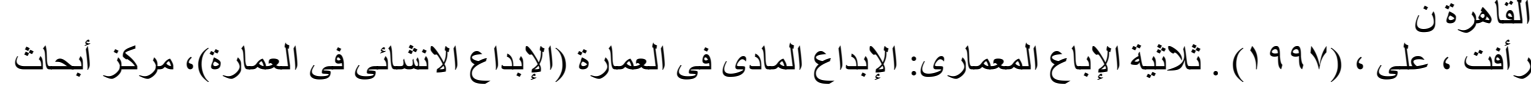

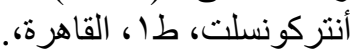

Salama , Ashraf, (1999) . Human Factor in Environement Designe, The Anglo Egyptian Bookshop, Cairo,.

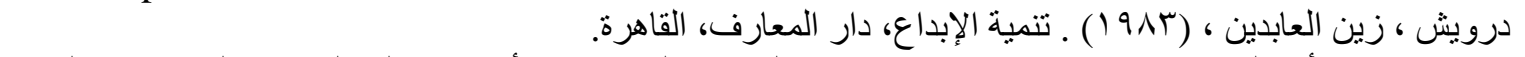

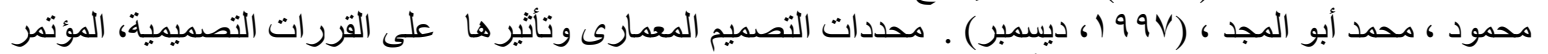

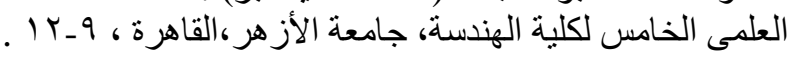

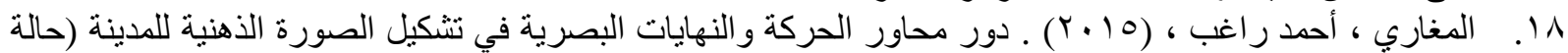

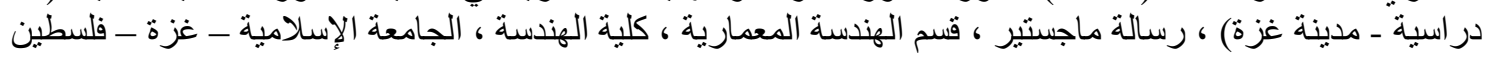

https://search.mandumah.com/Record/768542/Details

19. https://el-ma3lomaa.com/2017/11/8.html

20. https://www.archdaily.com/522344/sharifi-ha-house-nextoffice

21. https://en.wikipedia.org/w/index.php?title=Absolute_World\&oldid=885263026

22. https://www.architonic.com/en/project/ernst-giselbrecht-partner-dynamic-facade-kiefertechnic-showroom/5100449 
ب ا ـالملحق ( الاستبيان) :

الإستبيان تم لمعماريين فقط لتخصصهم و فهمهم لمتطلبات جودة الحياة و ملاحظاتهم الدقيقة في المعمار في أي ظروف

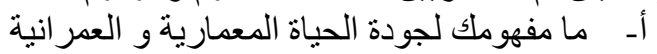

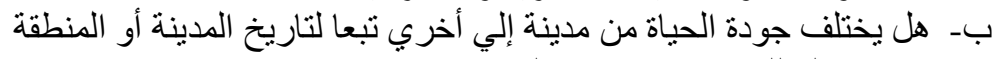
تــ ما مفهومك للمدينة الإقتصادية الحديثة

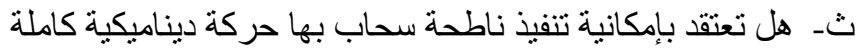

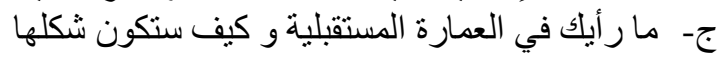

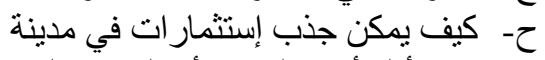

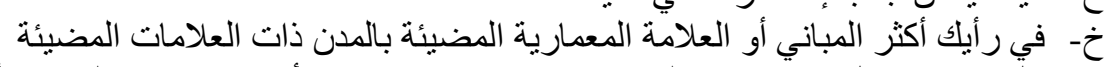

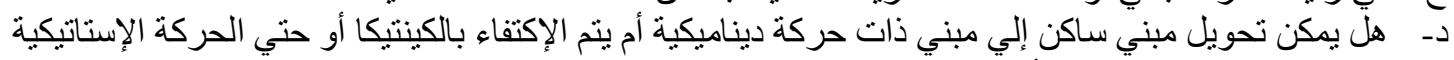
ذـ ما سبب ريادة المعماريين الأجانب دون ميني ذالمحليين 